UNIVERSIDADE DE SÃO PAULO

INSTITUTO DE GEOCIÊNCIAS

\title{
CLIMATIC EVOLUTION OF EASTERN SOUTH AMERICA DURING THE LAST DEGLACIATION: A PALEOCEANOGRAPHIC APPROACH
}

Maria Carolina Amorim Catunda

Orientador: Prof. Dr. Cristiano Mazur Chiessi

DISSERTAÇ̃̃O DE MESTRADO

Programa de Pós-Graduação em Geoquímica e Geotectônica

versão corrigida

SÃO PAULO

2016 
Autorizo a reprodução e divulgação total ou parcial deste trabalho, por qualquer meio convencional ou eletrônico, para fins de estudo e pesquisa, desde que citada a fonte.

Ficha catalográfica preparada pelo Serviço de Biblioteca e Documentação do Instituto de Geociências da Universidade de São Paulo

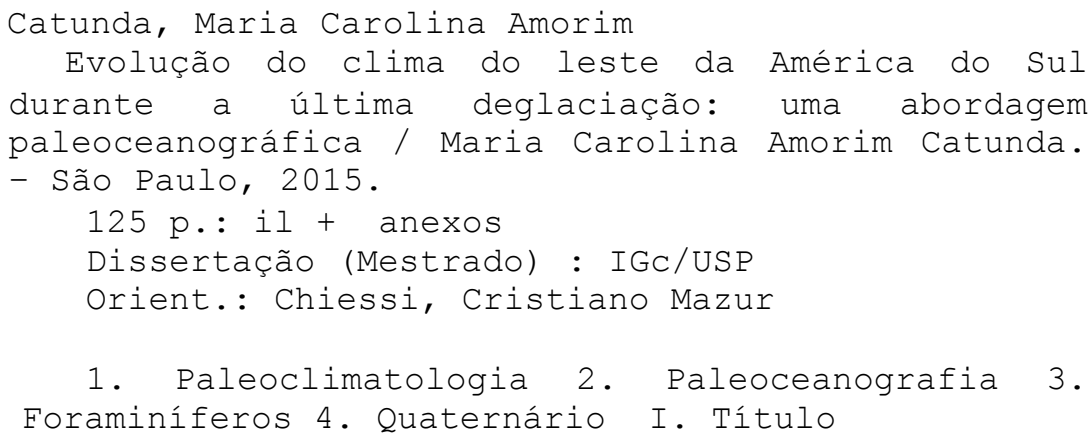


Whaaaaatttttt?????

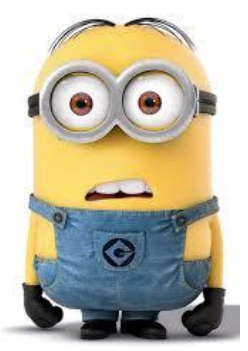

To my loved ones. 


\section{Acknowledgements / Agradecimentos}

I'd like to dedicate this dissertation to my parents, Maria Alice and Heitor for the support and love, which allowed me to pursue my aspirations, and to my dear brothers, Gustavo and Arthur, for being by my side. I thank my deeply loved friends, the old and the new, for the help and understanding, as well as for the good times and laughs. I thank my love, Daniel Rodelli, for making my life brighter.

To my official supervisor, Dr. Cristiano Chiessi, thank you for the opportunities and patience. To my unofficial supervisors Chico Bill and Dr. Juan Pablo Bernal, thank you for believing in me.

I thank my Brazilian colleagues, Adriana Perretti (:*), Marília Campos, Stefano Crivellari, Igor Venâncio, Thiago dos Santos, Cintia Yamashita and Nancy Kazumi for the productive discussions about work and life. To my friends in Bremen Melanie Schneider, Itxaso Ruiz, Barbara Safaric and Jessica Volz, thank you for making me feel at home. I thank Dr. Stefan Mulitza and Dr. Nicolás Strikis, for our conversations and scientific discussions that helped develop this dissertation.

For last but not least, I thank FAPESP (2013/14599-1 and 2014/26482-4) and CAPES for funding this project. 


\begin{abstract}
To support the current debate and actions to be taken about climatic consequences of anthropogenic release of $\mathrm{CO}_{2}$, a refined understanding about past climatic and oceanographic changes is necessary. The Atlantic Meridional Overturning Circulation (AMOC) plays a fundamental role in the oceanography and climate of the Atlantic realm, directly controlling stratification and distribution of water masses, the amount of heat that is transported by the ocean, and the cycling and storage of chemical species, such as carbon dioxide in the deep sea. The formation and circulation of Antarctic Intermediate Water (AAIW) is an important component of the upper branch of the AMOC, involved in the transport of heat and salt within the Southern Hemisphere subtropical gyre and driving high-low latitude climatic teleconnections. Reconstructing intermediate water properties is, therefore, important for understanding feedbacks within the ocean-climate system. However, information on AAIW evolution remains limited. AMOC oscillations and changes in heat distribution have strong implications for the South American climate, influencing moisture influx availability for the South American Summer Monsoon (SASM), via sea surface temperatures and Intertropical Convergence Zone positioning. Here we reconstruct AAIW isotopic signature during marine isotope stages 2 and 3 (41-12 cal kyr BP) using carbon and oxygen isotopes from benthic foraminifera (Cibicidoides and Uvigerina genera) of a radiocarbon dated marine sediment core $\left(1100 \mathrm{~m}\right.$ water depth and $20^{\circ} \mathrm{S}$, off the Brazilian coast). We find that AAIW's physical and chemical properties changed Heinrich stadials 3 and 4, probably as a consequence of AMOC decreased strength during these periods. We also reconstruct Last Glacial Maximum and deglacial (23-12 cal kyr BP) continental conditions over eastern Brazil based on Ti/Ca of our marine sediment core as a proxy for Doce River (draining eastern Brazil) terrigenous input. Most of the rainfall in the Doce River Basin is related to the activity of the SASM. Our $\mathrm{Ti} / \mathrm{Ca}$ record together with a speleothem $\delta^{18} \mathrm{O}$ composite from Lapa Sem Fim Cave, also in eastern Brazil, suggests a major decrease in precipitation during the Bølling-Allerød interstadial, likely related to a weakening of the SASM. We further compared our $\mathrm{Ti} / \mathrm{Ca}$ results with the output of the SYNTRACE run of the CCSM3 fully-coupled climate model with transient forcing for the last deglaciation. Geochemical records and model output show consistent results and suggest that eastern South America experienced the driest period of the whole last deglaciation during the Bølling-Allerød and that this dry spell was likely related to decreased SAMS intensity.
\end{abstract}

Keywords: paleoclimatology, paleoceanography, Quaternary, geochemistry, foraminifera, AMOC, millennial events, precipitation. 


\section{Resumo}

Para dar suporte ao atual debate sobre as consequências climáticas da liberação antropogênica de $\mathrm{CO}_{2}$ na atmosfera, o refinamento do conhecimento sobre mudanças climáticas e oceanográficas no passado é necessário. A Circulação de Revolvimento Meridional do Atlântico (CRMA) tem papel fundamental na oceanografia e clima das áreas sob influência do Oceano Atlântico, controlando diretamente a estratificação e distribuição de massas d'água, a quantidade de calor transportada pelo oceano e os ciclo e armazenamento de compostos químicos, como o $\mathrm{CO}_{2}$ em mar profundo. A formação e circulação da Água Intermediária Antártica (AIA), envolvida no transporte de calor e sal para o giro subtropical do Hemisfério Sul e nas teleconexões climáticas entre altas e baixas latitudes, é componente importante do ramo superior da CRMA. A reconstrução de propriedades de massas de água intermediárias é, portanto, importante para a compreensão dos sistemas de retroalimentação entre oceano-clima. No entanto, informações quanto a evolução da AIA continuam limitadas. Oscilações da CRMA e consequentes mudanças na distribuição de calor tem implicações importantes para o clima Sul Americano, influenciando a disponibilidade de umidade para o Sistema de Monções Sul Americano (SMSA), via temperatura da superfície marinha e posicionamento da Zona de Convergência Intertropical. Neste trabalho nós reconstruímos a assinatura isotópica da AIA durante os estágios isotópicos marinhos 2 e 3 (41-12 cal ka AP) usando isótopos de carbono e oxigênio de foraminíferos bentônicos (gêneros Cibicidoides e Uvigerina) de um testemunho de sedimentos marinhos datados por radiocarbono (1100 $\mathrm{m}$ de profundidade e a $20^{\circ} \mathrm{S}$ na costa do Brasil). Concluímos que propriedades físicas e químicas da AIA mudaram durante os estadiais Heinrich 3 e 4, provavelmente como consequência de enfraquecimento da CRMA durante estes períodos. Também reconstruímos as condições continentais do leste brasileiro entre o último máximo glacial e a deglaciação (23-12 cal ka AP) baseadas em razões $\mathrm{Ti} / \mathrm{Ca}$ de nosso testemunho de sedimentos marinhos como indicadoras de aporte terrígeno do Rio Doce. A maior parte da chuva que cai na Bacia do Rio Doce está relacionada a atividade do SMAS. Nosso registro de Ti/Ca em conjunto com $\delta^{18} \mathrm{O}$ de espeleotemas da Caverna Lapa Sem Fim, também no leste do Brasil, sugere diminuição marcante da chuva durante o interestadial Bølling-Allerød, provavelmente relacionada a enfraquecimento do SMAS. Ademais comparamos as razões de Ti/Ca com dados de saída da rodada SYNTRACE do modelo climático CCSM3 com forçantes transientes para a última deglaciação. Os registros geoquímicos e a saída do modelo mostram resultados consistentes entre si e sugerem que o leste da América do Sul passou pelo seu período mais seco de toda a última deglaciação durante o interestadial Bølling-Allerød, provavelmente relacionado ao enfraquecimento do SMAS.

\section{Palavras-chave: paleoclimatologia, paleoceanografia, Quaternário, geoquímica, foraminíferos, CRMA, eventos milenares, chuva.}




\section{List of abbreviations / Lista de abreviações}

AABW - Antarctic Bottom Water

AAIW - Antarctic Intermediate Water

AMOC - Atlantic Meridional Overturning Circulation

AMS - Accelerator mass spectrometry

BA - Bølling-Allerød Interstadial

$\mathrm{Ca}-$ Calcium

CDW - Circumpolar Deep Water

$\mathrm{CO}_{2}-$ Carbon dioxide

$\mathrm{C}_{\text {org }}$ - Organic carbon

DO - Dansgaard-Oeschger Interstadial

DIC - Dissolved inorganic carbon

$\delta^{13} \mathrm{C}$ - Isotopic ratio of ${ }^{13} \mathrm{C}$ relatively to ${ }^{12} \mathrm{C}$

$\delta^{13} \mathrm{C}_{\mathrm{c}}-\delta^{13} \mathrm{C}$ of Cibicidoides spp. samples

$\delta^{13} \mathrm{C}_{\mathrm{as}}-\delta^{13} \mathrm{C}$ on foraminiferal calcite due to air-sea fractionation processes

$\delta^{13} \mathrm{C}_{\mathrm{u}}-\delta^{13} \mathrm{C}$ of $U$. peregrina samples

$\delta^{18} \mathrm{O}$ - Isotopic ratio of ${ }^{18} \mathrm{O}$ relatively to ${ }^{16} \mathrm{O}$

$\delta^{18} \mathrm{O}_{\mathrm{c}}-\delta^{18} \mathrm{O}$ of Cibicidoides spp. samples

$\delta^{18} \mathrm{O}_{\text {civc }}$ - Ice volume corrected $\delta^{18} \mathrm{O}$ of Cibicidoides spp. samples

$\delta^{18} \mathrm{O}_{\mathrm{u}}-\delta^{18} \mathrm{O}$ of $U$. peregrina samples

$\delta^{18} \mathrm{O}_{\text {uivc }}$ - Ice volume corrected $\delta^{18} \mathrm{O}$ of $U$. peregrina samples

$\Delta \delta^{13} \mathrm{C}$ - variable offset between $\delta^{13} \mathrm{C}_{\mathrm{c}}$ and $\delta^{13} \mathrm{C}_{\mathrm{u}}$

$\Delta_{\text {offset }}$ - difference between glacial $\Delta \delta^{13} \mathrm{C}$ and interglacial $\Delta \delta^{13} \mathrm{C}$

EDP-XRF - Energy dispersive X-ray fluorescence

$\mathrm{Fe}-$ Iron

GAAIW - Glacial Antarctic Intermediate Water

GNAIW - Glacial North Atlantic Intermediate Water

HS - Heinrich Stadial

ITCZ - Intertropical Convergence Zone 
JAS - July, August and September (austral winter)

JFM - January, February and March (austral summer)

ka - kilo annum / calibrated kilo years before present (1950)

LCDW - Lower Circumpolar Deep Water

LGM - Last Glacial Maximum

MIS - Marine Isotope Stage

mbsl - meters below sea level

NADW - North Atlantic Deep Water

NBC - North Brazil Current

$\mathrm{NH}$ - Northern Hemisphere

OD - Older Dryas

OLD - Oldest Dryas

$\mathrm{P}^{2} \mathrm{~L}$ - Paleoceanography and Paleoclimatology Laboratory at the School of Arts, Sciences and Humanities of the University of São Paulo, Brazil

SA - South America

SACW - South Atlantic Central Water

SACZ - South Atlantic Convergence Zone

SH - Southern Hemisphere

SASM - South American Summer Monsoon

SSG - (Atlantic) Southern Subtropical Gyre

SST - Sea surface temperature

$\mathrm{Ti}-$ Titanium

UCDW - Upper Circumpolar Deep Water

VPDB - Vienna Pee Dee Belemnite

$\mathrm{XRF}$ - X-ray fluorescence

YD - Younger Dryas 


\section{List of Figures / Lista de Figuras}

Figure 2.1: Global termohaline circulation.

Figure 2.2: Position of the Atlantic latitudinal section and main characteristics of Atlantic water masses.

Figure 2.3: Monthly long term mean sea surface temperature (SST) and monthly long term mean precipitation.

Figure 2.4: Predominant AMOC modes as derived from the combined ${ }^{231} \mathrm{~Pa}{ }^{230}$ Th records. 10

Figure 2.5: Comparison of $\delta^{13} \mathrm{C}$ distribution along the western Atlantic for the modern ocean (GEOSECS) and during the Last Glacial Maximum.

Figure 2.6: Proxy records spanning from 10 to 70 cal kyr BP that demonstrate the close relationship between Greenland temperatures and rainfall records from the tropical Atlantic and China during the last glacial period......

Figure 3.1: Location of the Doce River Basin (black line) and marine sediment cores GeoB3227-2 (1340 mbsl) and GeoB3228-1 (1095 mbsl).

Figure 3.2: Doce River Canyon System and the location of marine sediment cores GeoB3228-1 and GeoB3227-2......

Figure 3.3: Schematic representation of the large-scale, upper level geostrophic currents and fronts in the South Atlantic Ocean.

Figure 3.4: Properties of the water column in the study area. 22

Figure 3.5: Histograms of monthly precipitation at selected stations from the Doce River drainage basin and mean annual cycle of the Doce River discharge.

Figure 4.1. General color and sampling schematics of marine sediment cores GeoB3228-1 and GeoB3227-2..

Figure 5.1: Age models and sedimentation rates for marine sediment cores GeoB3228-1 and GeoB3227-2..

Figure 5.2: Benthic foraminiferal stable oxygen and carbon isotopic records for the uppermost half of marine sediment core GeoB3228-1, divided by species.

Figure 5.3: Benthic foraminiferal stable oxygen and carbon isotopic records for marine sediment core GeoB3228-1.

Figure 5.4: Benthic foraminiferal stable oxygen and carbon isotopic records for uppermost half of marine sediment core GeoB3228-1, divided by species.

Figure 5.5: Ti/Ca and Fe/Ca records from cores GeoB3228-1 and GeoB3227-2.

Figure 6.1: Relative sea level (Lambeck and Chappel, 2001; updated in 2007) and $\ln (\mathrm{Fe} / \mathrm{Ca})$ of GeoB3228-1 and GeoB3227-2 versus age.

Figure 6.2: Ice volume corrected Cibicidoides $\delta^{18} \mathrm{O}$ composite interpolated every $1 \mathrm{kyr} ; \mathrm{C}$. wuellerstorfi, C. pachyderma, Cibicides spp. and Cibicidoides spp. $\delta^{18} \mathrm{O}$ record and $1 \mathrm{kyr}$ integrated interpolation; ice volume corrected $U$. peregrina $\delta^{18} \mathrm{O}$ record interpolated every $1 \mathrm{kyr}$; $U$. peregrina $\delta^{18} \mathrm{O}$ record and $1 \mathrm{kyr}$ integrated interpolation; antarctic temperature stack from five different ice cores (EDC, Vostok, Dome Fuji, TALDICE, and EDML)...... 
Figure 6.3: C. wuellerstorfi, C. pachyderma, Cibicides spp. and Cibicidoides spp. $\delta^{13} C$ record and 1 kyr integrated interpolation; U. peregrina $\delta^{13} \mathrm{C}$ record and 1 kyr integrated interpolation; antarctic composite ice core atmospheric $\mathrm{CO}_{2}$ data (WAIS, Siple Dome and TALDICE)............5I

Figure 6.4: Comparison between 1 kyr integrated interpolations of GeoB3228-1 U. peregrina $\delta^{13} \mathrm{C}$ record and Antarctic ice core atmospheric $\mathrm{CO}_{2}$ data composite

\section{List of Tables / Lista de Tabelas}

Table 3.1. Data from the selected monitoring stations for which histograms are shown in Figure 3.5

Table 4.1 Results of the preliminary selection of benthic foraminifera from core GeoB3228-1, considering the genera Cibicidoides/Cibicides and Uvigerina......

Table 5.1 Radiocarbon data available for the marine sediment cores investigated within this dissertation. 36 


\section{Summary / Índice}

Acknowledgements / Agradecimentos ............................................................................. i

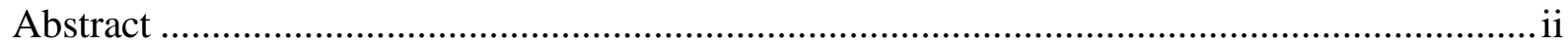

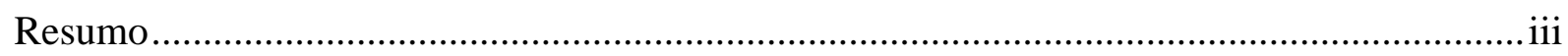

List of abbreviations / Lista de abreviações.......................................................................... iv

List of Figures / Lista de Figuras ........................................................................................... vi

List of Tables / Lista de Tabelas ........................................................................................ vii

1. Introduction and objectives / Introdução e objetivos ........................................................ 1

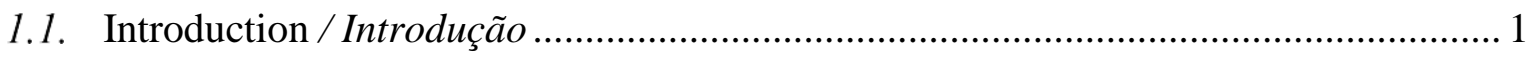

1.2. Objectives / Objetivos ................................................................................... 2

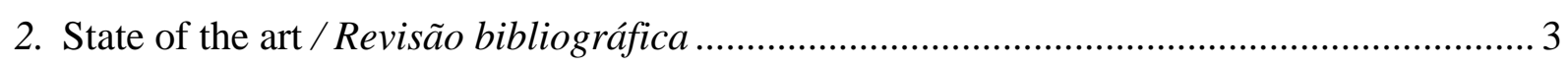

2.1. Modern oceanography and climate / Oceanografia e climatologia modernas ............. 3

2.1.1. The modern Atlantic Meridional Overturning Circulation / A Célula de Revolvimento Meridional do Atlântico no presente ............................................................ 3

2.1.2. Modern influence of the Intertropical Convergence Zone and insolation over the South American Monsoon System / Influência atual da Zona de Convergência Intertropical e insolação sobre o Sistema de Monções da América do Sul ......................... 5

2.2. Paleoceanography and paleoclimatology / Paleoceanografia e paleoclimatologia .... 8

2.2.1. Atlantic Meridional Overturning Circulation oscillations during the Last Glacial Maximum and Termination I / Oscilações da Célula de Revolvimento Meridional do Atlântico durante o Último Máximo Glacial e a Terminação I ........................................... 8

2.2.2. Water masses on the Brazil continental margin during the Last Glacial Maximum / Massas de água na margem continental do Brasil durante o Último Máximo Glacial .11 
2.2.3. Millenial scale climate oscillations during late glacial and Termination I / Oscilações climáticas de escala milenar durante a porção final do último período glacial e a Terminação I

2.2.4. The Bølling - Allerød Interstadial/ O Interestadial B $\phi l l i n g-A l l e r \phi d$. 14

3. Study area, modern oceanography and climatology / Área de estudo, oceanografia e climatologia modernas 17

3.1. Study area / Área de estudo.

3.2. Modern oceanography of the western South Atlantic adjacent to the Doce River shelf I Oceanografia moderna do oeste do Atlântico Sul adjacente à plataforma do Rio Doce . 20

3.3. Modern climatology of Doce River basin / Climatologia moderna da Bacia do Rio Doce 23

4. Materials and methods / Materiais e métodos 25

4.1. Materials - Marine sediment cores / Materiais - Testemunhos sedimentares marinhos 25

4.2. Methods / Métodos. 25

4.2.1. Marine sediment cores visual evaluation, sampling and sample processing / Avaliação visual dos testemunhos de sedimento marinho, amostragem e processamento das amostras. 25

4.2.2. AMS radiocarbon dating and age models / Datações radiocarbônicas AMS $e$ modelos de idade.

4.2.3. Benthic foraminifera selection strategy / Estratégia para seleção de foraminíferos bentônicos

4.2.4. $\delta^{18} \mathrm{O}$ and $\delta^{13} \mathrm{C}$ of benthic foraminifera $/ \delta^{18} O$ e $\delta^{13} \mathrm{C}$ de foraminíferos bentônicos 29

4.2.5. $\mathrm{Fe} / \mathrm{Ca}$ and $\mathrm{Ti} / \mathrm{Ca}$ ratios in oceanic basins as paleoclimatological proxies / Razões Fe/Ca e Ti/Ca como indicadores paleoclimáticos

4.2.6. Calibration of XRF-scanner data via EDP-XRF / Calibração de dados de scanner de XRF via EDP-XRF 
5.1. Radiocarbon ages and age models / Idades radiocarbônicas e modelos de idade .... 35

5.2. $\quad \delta^{18} \mathrm{O}$ and $\delta^{13} \mathrm{C}$ of benthic foraminifera $/ \delta^{18} \mathrm{O}$ e $\delta^{13} \mathrm{C}$ de foraminíferos bentônicos.... 37

5.3. Major elements in bulk sediment / Elementos maiores em sedimento total

6. Discussion / Discussão .46

6.1. Sedimentation on the core sites on the passage between the late Pleistocene and Holocene / Sedimentação no local dos testemunhos marinhos durante a passagem Pleistoceno tardio e Holoceno 46

6.2. Changes in southern sourced water masses isotopic signature in the western South Atlantic during the late glacial and Termination I

6.3. South American summer monsoon decreased intensity related to the Bølling-Allerød interstadial / Diminuição da intensidade do Sistema de monções de verão Sul Americano relacionado ao interestadial Bølling-Aller $\phi d$.

7. Conclusions / Conclusões 56

8. References / Referências Bibliográficas. 57

Attached manuscript. South American summer monsoon decreased intensity related to the Bølling-Allerød interstadial (Catunda et al., in prep). 


\section{Introduction and objectives / Introdução e objetivos}

\subsection{Introduction / Introdução}

The Atlantic Meridional Overturning Circulation (AMOC) plays a fundamental role in the oceanography and climate of the Atlantic realm. As such, AMOC activity directly controls stratification and distribution of water masses, the amount of heat that is transported by the ocean, and the cycling and storage of chemical species, such as carbon dioxide $\left(\mathrm{CO}_{2}\right)$ in the deep sea (Kuhlbrodt et al., 2007). Past changes in global atmospheric $\mathrm{CO}_{2}$ concentrations over interglacial and glacial cycles may have been driven by changes in ventilation and circulation of intermediate and deep waters (e.g., Siegenthaler and Wenk, 1984).

The formation and circulation of Antarctic Intermediate Water (AAIW) is an important component of the upper branch of the AMOC, involved in the transport of heat and salt within the Southern Hemisphere (SH) subtropical gyre (Talley, 1996). Upon its formation on the Subantarctic Frontal Zone, AAIW sequesters significant quantities of $\mathrm{CO}_{2}$ (Talley, 1996; Sabine et al., 2004), which are then widely distributed in SH oceans (Lynch-Stieglitz et al., 1994). Reconstructing intermediate water properties is, therefore, important for understanding feedbacks within the ocean-climate system. However, information on intermediate water mass evolution remains limited (Elmore et al., 2015).

The South American Summer Monsoon (SASM) is one of the major monsoon systems in the SH and the most important climatic feature in South America (SA; Vera et al., 2006; Carvalho et al., 2012). Its strength is dependent on insolation with moisture availability modulated by Intertropical Convergence Zone (ITCZ) positioning (Vera et al., 2006). Given that the former is controlled by sea surface temperatures (SST; Nobre and Shukla, 1996), AMOC oscillations and changes in heat distribution have strong implications for the South American climate.

Deglaciation periods offer the possibility to study in detail the impact of rapid climatic changes on the environment (Wohlfarth, 1996). The last deglaciation, or Termination I, started between 20 and $18 \mathrm{kyr}$ ago in the $\mathrm{SH}$ with continuous increase in temperature and greenhouse gas concentration (Petit et al., 1999; Marcott et al., 2014). For over 3 kyr Antarctica warmed while Greenland and the North Atlantic remained cold. The Northern 
Hemisphere (NH) cold period between 18.1 and 14.7, known as Heinrich stadial 1 (HS1), ended abruptly at the start of the Bølling-Allerød interstadial (Rasmussen et al., 2006). This abrupt transition was marked by the restart of the AMOC (McManus et al., 2004) and warming in NH (Petit et al., 1999), with a corresponding return to cold conditions in the south (Blunier et al., 1997).

Previous studies have correlated pulses of terrigenous input with cold events in the NH off the coast of generally dry northeastern SA (Arz et al., 1998; Arz et al., 1999; Jennerjahn et al., 2004; Jaeschke et al., 2007; Nace et al., 2014). Yet, the $23-7^{\circ} \mathrm{S}$ sector of the Brazilian continental margin remains completely void of studies. This is a particularly relevant sector of the continental margin for reconstructing the strength of the SASM. Oxygen isotopic oscillations from stalagmites have provided a glimpse of how continental climate responded to past millennial scale abrupt events (Wang et al., 2008a; Stríkis et al., 2015). However the several other areas of the continent and proximal marine environments are still not resolved.

The mere possibility that the AMOC could change was already a strong motivator to understand how it may have oscillated in the past (Lynch-Stieglitz et al., 2007). A recent study confirmed that the AMOC is currently weakening (Rahmstorf et al., 2015), highlighting the urgency of researching about the impacts of past AMOC strength oscillations and abrupt climatic events during the glacial and deglacial periods.

\subsection{Objectives / Objetivos}

The main objectives of this dissertation are:

(i) Investigate the isotopic evolution of southern sourced water masses (i.e., AAIW, UCDW and their glacial correspondents) in the western tropical South Atlantic throughout the last glacial and Termination I, and suggest its driving mechanisms;

(ii) Determine changes in major elements of sediments from the western tropical South Atlantic throughout the last glacial and Termination I, and suggest its driving mechanisms; 


\section{State of the art / Revisão bibliográfica}

\subsection{Modern oceanography and climate / Oceanografia e climatologia modernas}

\subsubsection{The modern Atlantic Meridional Overturning Circulation / A Célula de}

Revolvimento Meridional do Atlântico no presente

The Atlantic Meridional Overturning Circulation (AMOC), correspondent to the Atlantic section of the global termohaline circulation, plays a fundamental role in the oceanography and climate of the Atlantic realm. The ocean affects climate through its high heat capacity relative to the surrounding land, thereby moderating daily, seasonal and interannual temperature fluctuations, and through its ability to transport large amounts of heat polewards, whereas freshwater input to high latitudes and low-latitude evaporation tend to brake this flow (Clark et al., 2002). The AMOC is responsible for much of the total oceanic poleward heat transport in the Atlantic, peaking at about $1.2 \pm 0.3 \mathrm{PW}\left(1 \mathrm{PW}\right.$ equals $10^{15}$ Watts) at $24^{\circ} \mathrm{N}$ (Ganachaud and Wunsch, 2000). The northward-flowing Atlantic surface waters are warm, whereas the southward-flowing deep waters are cold defining a meridional heat flux and a net northward transport of heat (Figure 2.1).

The AMOC activity directly controls stratification and distribution of water masses, the amount of heat that is transported by the ocean, and the cycling and storage of chemical species, such as carbon dioxide $\left(\mathrm{CO}_{2}\right)$ in the deep sea (Kuhlbrodt et al., 2007). It can be divided in four main branches: upwelling processes bringing older water from depth to near the ocean surface, surface currents that transport relatively light warm waters toward high latitudes, deepwater formation regions where waters become denser and sink, and deep currents closing the loop. These four branches span the entire Atlantic on both hemispheres, forming a circulation system that consists of two overturning cells, a deep one with North Atlantic Deep Water (NADW) and an abyssal one with Antarctic Bottom Water (AABW; Kuhlbrodt et al., 2007). 
Warm and saline waters from the Southern Subtropical Gyre (SSG), with contribution of the waters brought by the Agulhas Current from the Indian Ocean, cross the Equator via the North Brazil Current (NBC), and ultimately contribute to the northward flowing Gulf Stream. At high latitudes of the North Atlantic, these high salinity surface and intermediate waters lose buoyancy as they transmit heat to the atmosphere and sink forming the southward flowing NADW.

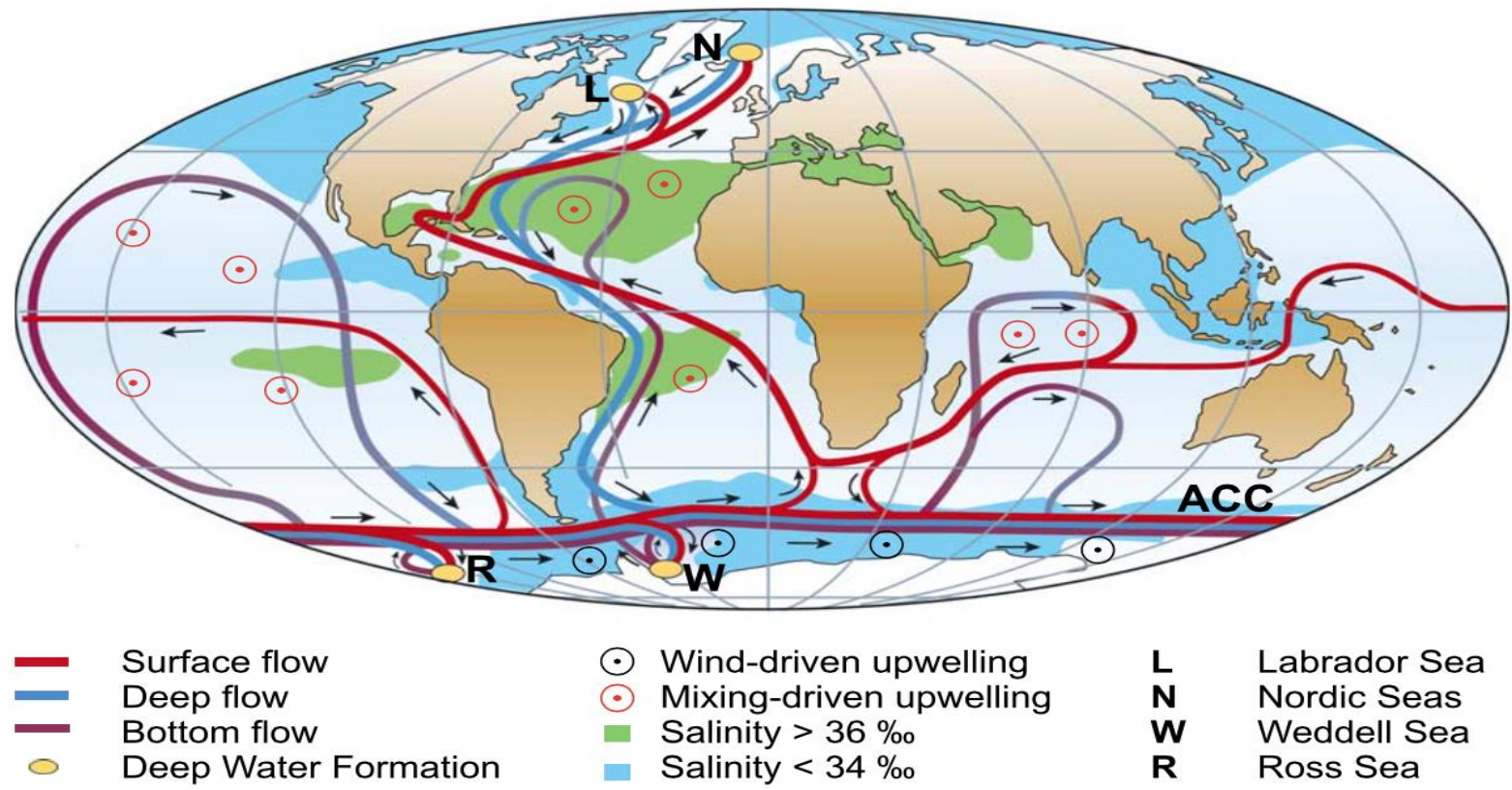

Figure 2.1: Global termohaline circulation. Extracted from Kuhlbrodt (2007).

Deep-water formation in the Southern Ocean occurs along the Antarctic continental shelf in the Weddell and Ross Seas either through intense evaporation or, more typically, through brine rejection that produces dense waters that sink along the slope (Killworth, 1983).

As a result, the North Atlantic surface is relatively warmer and saltier than its equivalent in the South Atlantic. South of the Equator, the nutrient poor NADW occupies from 1500 to $4000 \mathrm{~m}$ water depth and lies within the density range of the northward flowing Circumpolar Deep Water (CDW). The latter is then divided in two layers: Upper Circumpolar Deep Water (UCDW) and Lower Circumpolar Deep Water (LCDW), each of them less saline, richer in nutrients and lower in oxygen than NADW (Reid et al., 1977; Figure 2.2). UCDW is defined as a local oxygen and temperature minimum located below the salinity minimum and local oxygen maximum characteristic of the Antarctic Intermediate Water (AAIW; Tsuchiya and Talley, 1994). Under LCDW, AABW bathes the South Atlantic sea floor below $4000 \mathrm{~m}$ with cold and nutrient rich waters (Figure 2.2). 


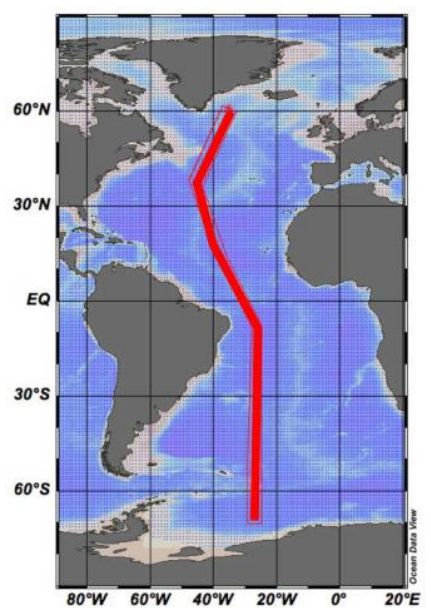

a
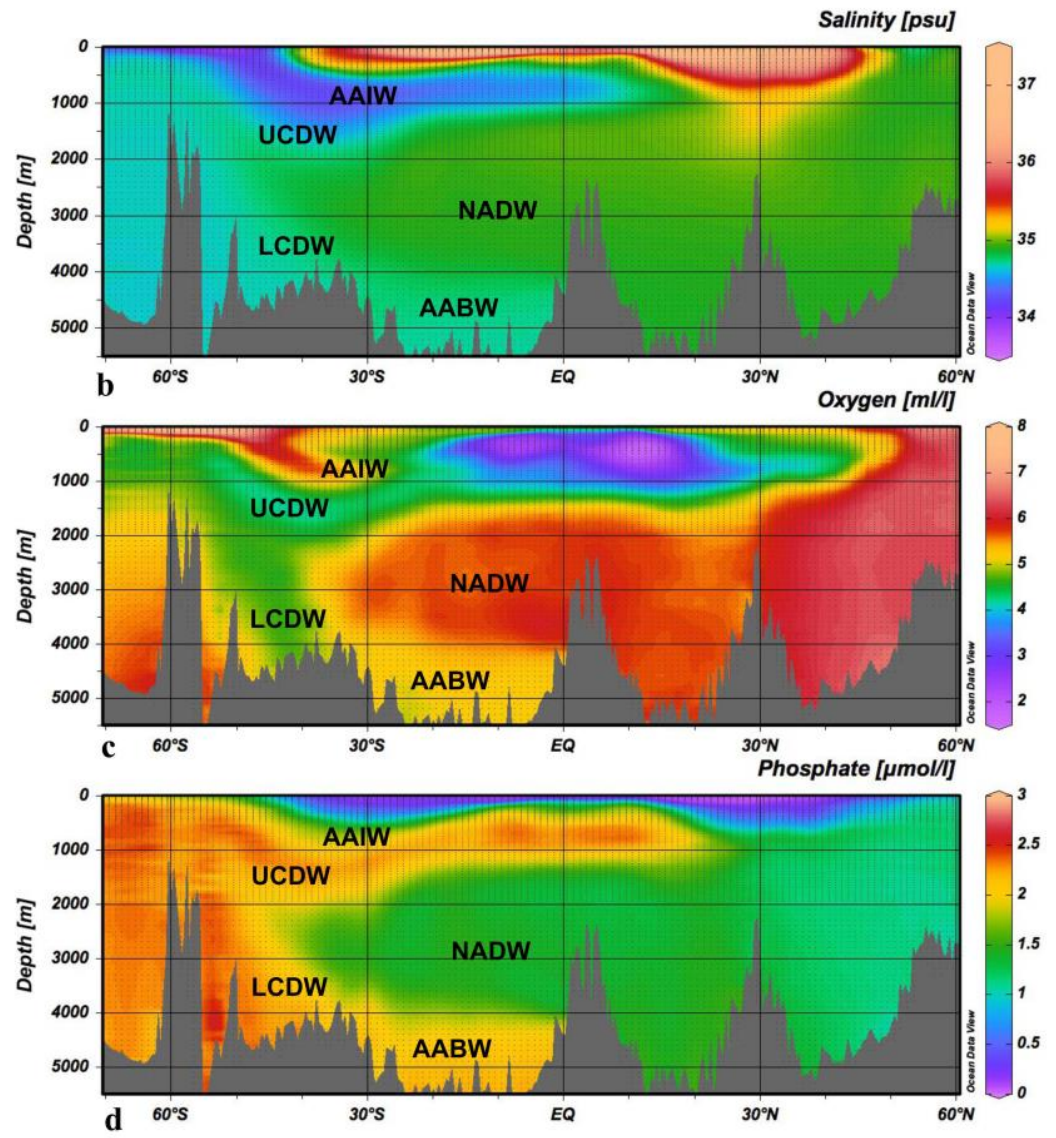

Figure 2.2: (a) Position of the Atlantic latitudinal section and (b, c, and d) main characteristics of Atlantic water masses. (b) Long-term mean salinity along the Atlantic (color-scale shading) (Zweng et al., 2014); (c) Long-term mean oxygen along the Atlantic (color-scale shading) (Garcia et al., 2014a); (d) Long-term mean phosphate along the Atlantic (color-scale shading) (Garcia et al., 2014b). Water masses are shown schematically by their acronyms: AABW - Antarctic Bottom Water, AAIW - Antarctic Intermediate Water, LCDW - Lower Circumpolar Deep Water, NADW North Atlantic Deep Water, and, UCDW - Upper Circumpolar Deep Water. This figure was prepared using Ocean Data View 4 (Schlitzer, 2015).

\subsubsection{Modern influence of the Intertropical Convergence Zone and insolation over the}

\section{South American Monsoon System / Influência atual da Zona de Convergência}

Intertropical e insolação sobre o Sistema de Monções da América do Sul

The Intertropical Convergence Zone (ITCZ) corresponds to a tropical belt of minimum pressure and deep convergence of the trade winds from both hemispheres over the equatorial oceans (Figure 2.3). It migrates seasonally towards the hemisphere being warmed in relationship to the other, shifting latitudinally in response to zonal sea surface temperatures (SST) gradients, which itself contributes to the distribution of sea level pressure and winds 
(Nobre and Shukla, 1996; Chiang and Kushnir, 2002; Schneider et al., 2014). The Atlantic section of the ITCZ migrates seasonally reaching its northernmost location, $10^{\circ} \mathrm{N}$, in August and southernmost, $1^{\circ} \mathrm{S}$, in March (mean latitudes at longitude $30^{\circ} \mathrm{W}$; Nobre and Shukla, 1996). Nevertheless, it has been suggested that during abrupt cooling events on the Northern Hemisphere (NH) it migrated further southward of the Equator (e.g., Deplazes et al., 2013).

The South American Summer Monsoon (SASM) has its onset in October, when moisture influx to the Amazon Basin from the Atlantic Ocean is intensified due to increased thermal gradients between land and sea, stronger trade winds, and the southward shift on the ITCZ position (Vera et al., 2006). Efficient transport of humidity from the Tropical Atlantic into South America (SA), reaches the Amazon Basin, where intense convective activity takes place.

The SASM most active phase is between December and February (austral summer), when a deep continental low forms over the Chaco region (due to insolation increase in the Southern Hemisphere, around $25^{\circ} \mathrm{S}$; Seluchi et al., 2003) and forces the easterly winds over the Amazon basin to turn southward, channeled via Low Level Jets (LLJ) between the eastern slope of the Andes and the Brazilian Plateau (Garreaud et al., 2009). During this peak phase, a prominent warm-core anticyclone establishes itself over the elevated Altiplano of the central Andes, the Bolivian High (BH), defined by Lenters and Cook (1997) as "a collective response to precipitation in the Amazon, central Andes, and South Atlantic Convergence Zone (SACZ), with its position over the Altiplano being largely the result of Amazonian precipitation". The latent heat release over the Amazon Basin and the establishment of the BH are also connected to the development of SACZ, a transient convective system characterized by a NW-SE nebulosity band formed by transport of Amazon moisture via LLJ to southeastern SA (Figure 2.3) and the Atlantic (Liebmann et al., 1999; Carvalho et al., 2004; Vera et al., 2006). The intensity of the SASM is mainly influenced by insolation, which is modulated by precession and excentricity, and by the dynamics of the ITCZ. Higher (lower) austral summer insolation over the Southern Hemisphere ( $\mathrm{SH})$ strengthens (weakens) the monsoon system by increasing (decreasing) the land-sea thermal gradient. On the other hand, the ITCZ position modulates the amount of humidity influx to the Amazon Basin and southeastern SA. The SASM has its demise in April (Marengo et al., 2001; Raia and Cavalcanti, 2008). 

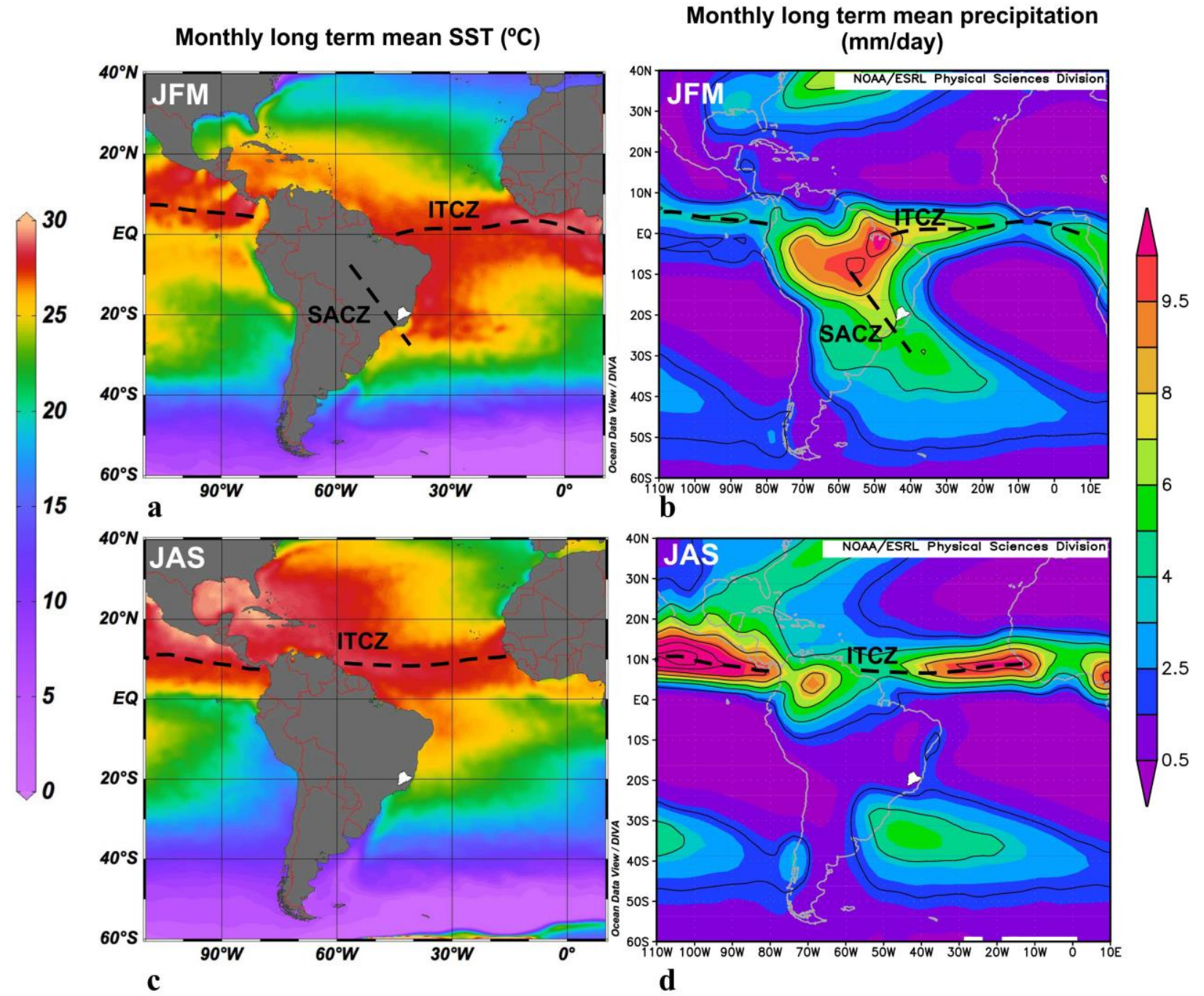

Figure 2.3: Monthly long term mean sea surface temperature (SST) (Locarnini et al., 2013) and monthly long term mean precipitation (Xie and Arkin, 1997). (a) and (b) refer to the austral summer (January-March), and (c) and (d) refer to the austral winter (JulySeptember). Doce River Basin location is marked in white. Intertropical Convergence Zone (ITCZ) and South Atlantic Convergence Zone (SACZ) are marked in black. Figure partially produced with Ocean Data View 4 (Schlitzer, 2015). 
During the austral winter, central SA (including southern Amazonia) experiences the dry season with maximum continental rainfall occurring to the north of the equator. Further south, precipitation is associated with moisture brought by extratropical cyclones and cold fronts (Garreaud et al., 2009).

The SACZ is evident year round but more intense during austral summer (the SASM season), when it is connected with the area of convection over the central part of the continent, producing episodes of intense rainfall over much of southeastern SA (Liebmann et al., 1999). Warm anomalies in SST in subtropical South Atlantic are associated with southward displacement of the SACZ with contributes to increase precipitation over southeastern SA (Diaz et al., 1998; Barros et al., 2000).

\subsection{Paleoceanography and paleoclimatology / Paleoceanografia $e$ paleoclimatologia}

\subsubsection{Atlantic Meridional Overturning Circulation oscillations during the Last Glacial Maximum and Termination I / Oscilações da Célula de Revolvimento Meridional do Atlântico durante o Último Máximo Glacial e a Terminação I}

Extreme, abrupt climate oscillations during the last glacial cycle were modulated by changes in ocean circulation and atmospheric forcing (Rahmstorf, 2002). Data and models both suggest that abrupt climate change during the last glaciation originated through changes in the AMOC in response to changes in the hydrological cycle or freshwater input in the high latitudes of the $\mathrm{NH}$. Atmospheric and oceanic responses to these changes were then transmitted globally through a number of feedbacks (Clark et al., 2002).

Although theoretical studies and ocean general circulation model experiments suggest that the AMOC may have multiple equilibria, paleoceanographic studies focus on three AMOC states or modi, characterized during specific timings as the Last Glacial Maximum (LGM, 19-23 cal kyr BP; Mix et al., 2001), the last deglaciation and modern times (Alley and Clark, 1999). There's agreement on that transitions between the equilibria states were triggered and/or associated to anomalies in the freshwater fluxes at the sea surface (LynchStieglitz et al., 2007). 
The existence of different AMOC states in the past has been first proposed and discussed mostly on the basis of nutrient tracers such as $\delta^{13} \mathrm{C}$ (Sarnthein et al., 1994), that are inversely correlated to nutrient content and $\mathrm{Cd} / \mathrm{Ca}$ in tests of benthic foraminifera (see section 4.2.4). Like the major nutrients, $\mathrm{Cd}$ is taken up by organisms at the sea surface and released at depth as the organic material is decomposed. The agreement between reconstructions based on these two water-mass tracers provides increased confidence in the overall picture.

Deep and vigorous overturning circulation, similar to the modern state, has persisted for most of the last glacial cycle, dominating the oceanic circulation in the Atlantic (Böhm et al., 2015). During deep glacial conditions (mainly glacial maxima), however, the upper cell of the AMOC may have been weaker and southern-sourced waters (SSW) advanced northwards and upwards in the water column, while NADW sank to depths of less than $2.500 \mathrm{~m}$ (Labeyrie et al., 1992). With the decrease of NADW formation, such as during the LGM, high nutrient/low $\delta^{13} \mathrm{C}$ waters, like the modern SSW (i.e., AAIW, CDW and AABW) may have partially replaced nutrient poor NADW and a large part of the deep Atlantic Ocean was bathed by deep waters advected from the Southern Ocean (Duplessy et al., 1984; Curry and Oppo, 2005; Lynch-Stieglitz et al., 2007). This shallower NADW is generally termed Glacial North Atlantic Intermediate Water (GNAIW) in paleoceanographic studies.

More significant slowdowns of the AMOC, probably related to iceberg discharges and increased freshwater input at the high latitudes of the $\mathrm{NH}$, happened during Heinrich Stadials (HS; Böhm et al., 2015). The Heinrich-like mode of the AMOC is characterized as a quasihalt in NADW formation during HS1, for instance (Rahmstorf, 2002; McManus et al., 2004). In contrast, the AMOC remained active during Dansgaard-Oeschger Interstadials (DO), abrupt warm events in the NH defined in ice cores from Greenland (Böhm et al., 2015).

Furthermore, McManus et al. (2004) used measurements of ${ }^{231} \mathrm{~Pa} /{ }^{230} \mathrm{Th}$ to trace the strength of the AMOC since the LGM and confirmed that the AMOC was nearly, or completely, eliminated during cold abrupt deglacial intervals in the North Atlantic region, namely HS1 and the Younger Dryas (YD; Figure 2.4).

In the South Atlantic, low $\delta^{13} \mathrm{C}$ values (correlated with glacial SSW or more specifically the glacial correspondents of AAIW, i.e., GAAIW, and UCDW, in this case) have been documented between $\sim 1600$ and $2500 \mathrm{~m}$ in the western side of the basin (Tessin and Lund, 2013), and above $1800 \mathrm{~m}$ in the tropical Atlantic (Zahn and Stüber, 2002; Lynch-Stieglitz et 
al., 2014), early in the deglaciation. While a few studies suggested that greater northward advection of GAAIW during HS1 caused low $\delta^{13} \mathrm{C}$ at relatively shallow depths (Rickaby et al., 2005; Pahnke et al., 2008), more recent studies using cores from modern AAIW depths suggest that the northward extent of GAAIW decreased during HS1 and the YD, presumably in response to a reduced AMOC (Xie et al., 2012; Huang et al., 2014).

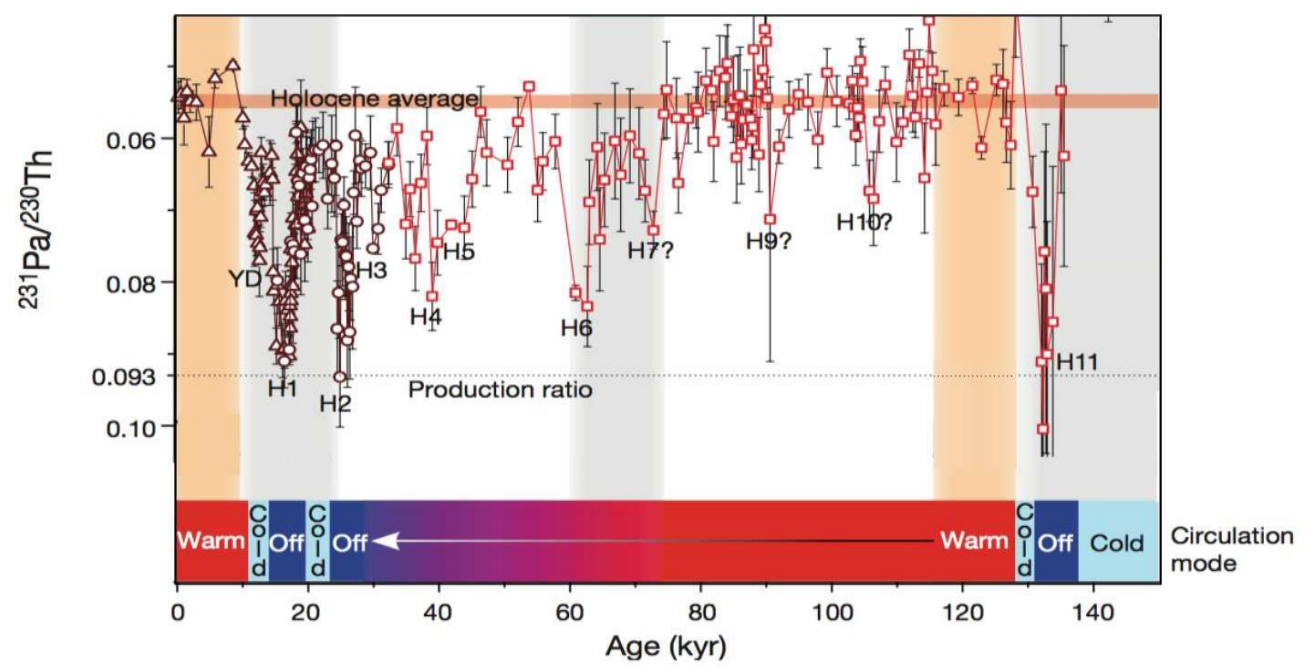

Figure 2.4: Predominant AMOC modes as derived from the combined ${ }^{231} \mathrm{~Pa} /{ }^{230} \mathrm{Th}$ records. Figure extracted from Böhm et al. (2015). Open red squares: Bermuda Rise ${ }^{231} \mathrm{~Pa} /{ }^{230} \mathrm{Th}$ data. Dark red triangles: ${ }^{231} \mathrm{~Pa} /{ }^{230} \mathrm{Th}$ data from McManus, 2004. Dark red circles: ${ }^{231} \mathrm{~Pa} /{ }^{230} \mathrm{Th}$ data from Lippold et al. 2009. HS1-HS11 mark the timing of major iceberg surges in the North Atlantic (Rasmussen et al., 2003) when ${ }^{231} \mathrm{~Pa} /{ }^{230} \mathrm{Th}$ shifts towards the production ratio of 0.093 . Grey shadings (MISs 2,4 and 6) mark glacial conditions, and orange shadings indicate interglacials (MISs 1 and 5e).

It is still not clear if the AMOC has always controlled or at times only responded to abrupt climatic oscillations during the last glacial period (Böhm et al., 2015). Nevertheless, ice cores show that Antarctica cooled during the major warm phases of the Greenland DO cycles and vice versa (Blunier and Brook, 2001; EPICA Community Members, 2006), supporting the idea of an interhemispheric redistribution of heat (bipolar seesaw; EPICA Community Members, 2006; Barker et al., 2009). WAIS Divide Project Members (2015) results demonstrated north-to-south directionality of the abrupt climatic signal, propagated to the SH high latitudes by oceanic processes (abrupt Greenland warming led Antarctic cooling onset by $218 \pm 92$ years for D-O events, including the Bølling event, and Greenland cooling led onset of Antarctic warming by $208 \pm 96$ years). 


\subsubsection{Water masses on the Brazil continental margin during the Last Glacial}

Maximum / Massas de água na margem continental do Brasil durante o Último

\section{Máximo Glacial}

Along the Brazil Margin, South Atlantic $\delta^{13} \mathrm{C}$ values were much lower than North Atlantic values at nearly every water depth during the LGM. Curry and Oppo (2005) updated the glacial western Atlantic cross section published by Duplessy et al. (1988) and indicated that above $2000 \mathrm{~m}$, the bathymetric $\delta^{13} \mathrm{C}$ gradients in the South Atlantic revealed the presence of two main water masses (Figure 2.5). The shallower, between 800 and $1200 \mathrm{~m}$ and centered at $1000 \mathrm{~m}$ water depth, was most likely sourced in the Southern Ocean and was interpreted as the glacial equivalent of AAIW (GAAIW). Centered at $1500 \mathrm{~m}$ and derived from the north there was another mid depth water mass, interpreted as the southern expression of GNAIW.
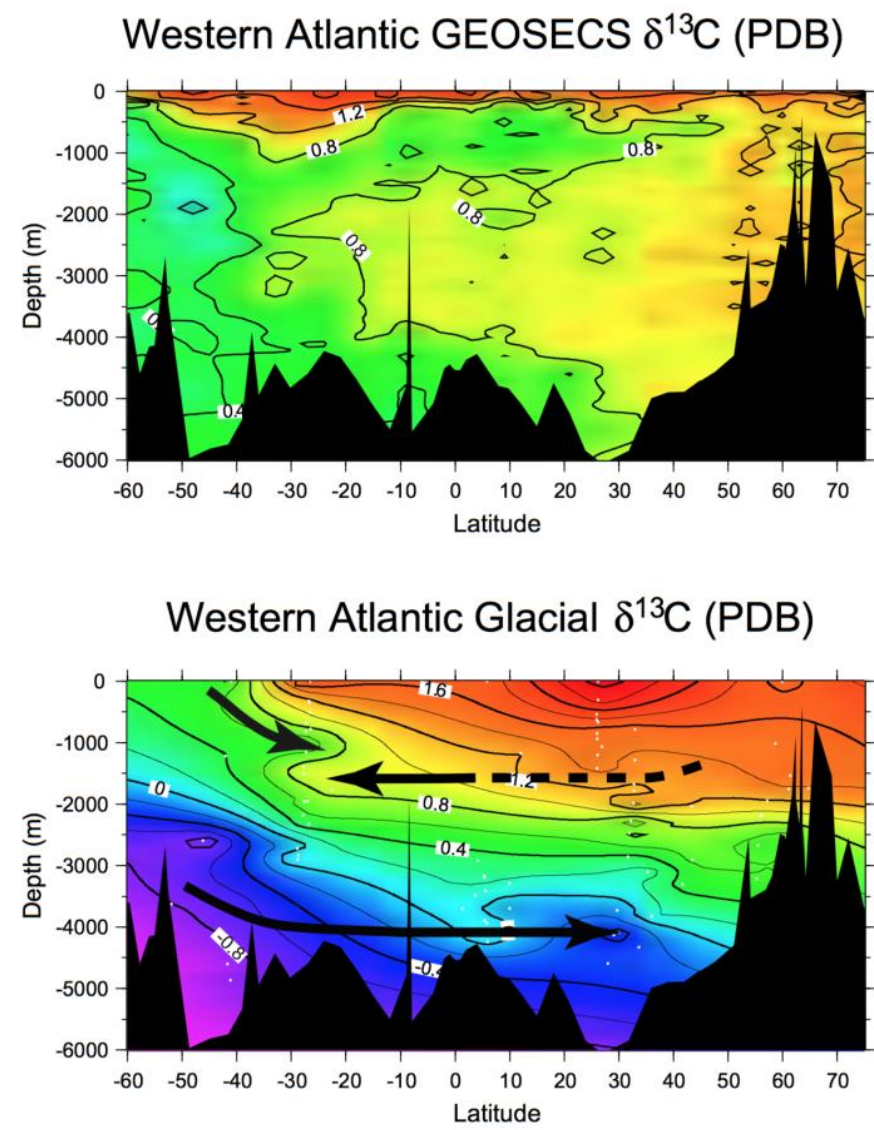

Figure 2.5: Comparison of $\delta^{13} \mathrm{C}$ distribution along the western Atlantic for the modern ocean (GEOSECS) and during the Last Glacial Maximum. Extracted from Curry and Oppo, 2005. 
Still according to Curry and Oppo (2005), at $27^{\circ} \mathrm{S}$ and during the LGM, GAAIW had a $\delta^{13} \mathrm{C}$ value of about $0.3-0.5 \%$. Oppo and Horowitz (2000) had already identified this water mass as similar to AAIW but without the relatively high $\delta^{13} \mathrm{C}$ value caused by air-sea exchange.

GNAIW originated in the North Atlantic with a $\delta^{13} \mathrm{C}$ value of about $1.5 \%$ and reached the Brazil Margin with $\delta^{13} \mathrm{C}$ values of $>0.8 \%$. Its much lower $\delta^{13} \mathrm{C}$ value in the South Atlantic implies that GNAIW underwent significant aging along its flow path or its $\delta^{13} \mathrm{C}$ value resulted from mixing with a water mass of lower $\delta^{13} \mathrm{C}$.

Curry and Oppo (2005) reported LGM AABW as the third main water mass in the South Atlantic (below GNAIW), flowing from the deep Southern Ocean and originating with an end-member $\delta^{13} \mathrm{C}$ value of $-0.2 \%$ and possibly as low as $-0.9 \%$ (Ninnemann and Charles, 2002).

\subsubsection{Millenial scale climate oscillations during late glacial and Termination I /}

Oscilações climáticas de escala milenar durante a porção final do último período glacial e a Terminação I

The last glacial period exhibited abrupt climatic oscillations which were primarily defined in the $\mathrm{NH}$ through $\delta^{18} \mathrm{O}$ analysis of ice cores from the Greenland Ice Sheet (Greenland Ice Core Project and Greenland Ice Sheet Project 2, GRIP and GISP2, respectively; Langway et al., 1985; Grootes and Stuiver, 1997; Figure 2.6). These abrupt warm events were termed Dansgaard-Oeschger (DO). Cold events, defined by concentration of Ice Rafted Debris (IRD) -rich layers within marine sediment cores from the high latitudes of the North Atlantic were termed Heinrich (Bond et al., 1992).

Later on, Peterson et al. (2000), for instance, showed that the abrupt changes described for the high latitudes of the $\mathrm{NH}$ were also recorded in the tropics. They based their conclusions in a 90,000-year sediment record from the anoxic Cariaco Basin off the coast of northern Venezuela (Figure 2.6). Variations in the terrigenous input to Cariaco Basin reflected changes in the hydrological cycle related to the Atlantic ITCZ, which resulted in color reflectance variations. Within dating uncertainty, the Cariaco record matches the abrupt climate change showed in the Greenland ice cores. Another record, $\delta^{18} \mathrm{O}$ obtained from stalagmites from Hulu Cave in China (Figure 2.6), also exhibited strong resemblance to the 
Greenland $\delta^{18} \mathrm{O}$ record, showing all major Greenland DOs (Wang et al., 2001). These records suggested a strong and fast linkage between the high-latitude North Atlantic temperatures with rainfall in the Atlantic ITCZ and Asian monsoon regions.

Heinrich Stadials impacted continental tropical climates mainly through changes in intensity of monsoon systems. In SA, during these events, a significant decrease in North Atlantic SST shifted the ITCZ location southwards, strengthening the SASM (Wang et al., 2004). In the NH, the same southward shift of the ITCZ associated with an expansion of the Siberian extratropical anticyclone reduced the Asian Monsoon intensity (Wang et al., 2001; Wang et al., 2008b).

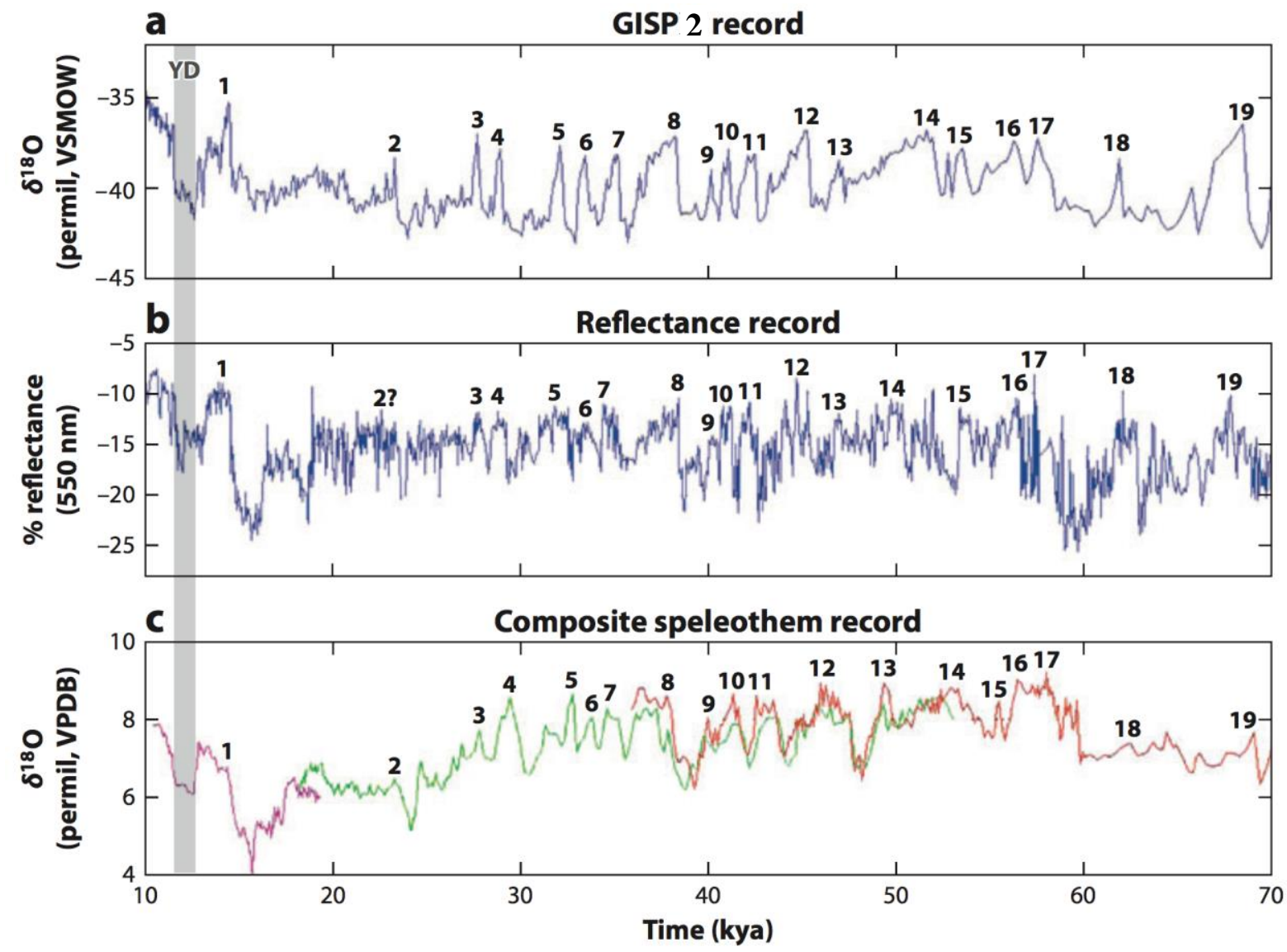

Figure 2.6: Proxy records spanning from 10 to 70 cal kyr BP that demonstrate the close relationship between Greenland temperatures and rainfall records from the tropical Atlantic and China during the last glacial period. (a) Greenland temperatures during the last glacial period, as recorded by $\delta^{18} \mathrm{O}$ from the Greenland Ice Sheet Project 2 (GISP2) core (Grootes and Stuiver, 1997). Interstadial (warm) events are numbered. (b) 550-nm reflectance record from a sediment core from the Cariaco Basin (Peterson et al., 2000), resulting from changes to the terrigenous input that reflect continental hydrological changes. (c) Stable oxygen isotope record from speleothem records in Hulu Cave, China (Wang et al. 2001). Different-colored lines indicate the different speleothem records from the same cave. The timing of the Younger Dryas (YD) cold event is shown, banded in gray. Extracted from Chiang et al. (2012). 
A modeling study by Chiang et al. (2003) highlighted the sensitivity of the Atlantic ITCZ position during the last glacial to changes in both land ice and sea ice extent. Together, modeling efforts are consistent with the hypothesis that AMOC variations, and their effect on heat transport, hemispheric SST patterns, and ITCZ position, can be invoked to explain the strong covariation observed between Greenland and Cariaco Basin proxy records (Hughen et al., 1996; Peterson et al., 2000; Chiang and Friedman, 2012).

In Brazil, the first studies on the impact of millennial abrupt events were (Arz et al., 1998; Arz et al., 1999), based in terrigenous input and planktonic foraminifera $\delta^{18} \mathrm{O}$ off $\mathrm{NE}$ Brazil. They showed increased terrigenous input during Heinrich events due to a southward shift of the ITCZ. Within the continent, series of $\delta^{18} \mathrm{O}$ from stalagmites confirmed the antiphase correlation between the intensity of the Asian and South American monsoon systems, demonstrated that stalagmite growth in caves of northeastern Brazil occurred only during wet phases synchronous with Heinrich events (Wang et al., 2004; Wang et al., 2007) and related negative $\delta^{18} \mathrm{O}$ excursions with SAMS intensification in speleothems from caves in southeastern SA (Cruz et al., 2005a; Cruz et al., 2005b; Cruz et al., 2006; Wang et al., 2007). Other factors controlling regional paleoclimatic changes included latitudinal variations in the AMOC (Wang et al., 2007; Cruz et al., 2009).

\subsubsection{The Bølling - Allerød Interstadial/ O interestadial Bølling-Allerød}

The historical and widely employed nomenclature for the main climatic events that occurred during Termination I include (from oldest to youngest; Mangerud et al., 1974) the Oldest Dryas (OLD), Bølling, Older Dryas (OD), Allerød, and Younger Dryas (YD). These terms were established in the beginning of the $20^{\text {th }}$ century, primarily describing biostratigraphic changes, more specifically changes in the content of palynomorphs in sediment layers, in Danish lakes. The alternation between layers containing pollen from Dryas octopetala, characteristic of tundra, and remains of Bertulaceae family, adjusted to temperate climate, indicated the oscillation between extremely cold and milder climates, respectively (Iversen, 1954; Anderson, 1997).

In this sense, OLD is chronostratigraphically poorly defined, being usually replaced by Heinrich Stadial 1 because of the apparent synchronicity (Rasmussen et al., 2014). The term $\mathrm{OD}$, referring to a brief relatively cold phase between Allerød and Bølling warm phases (Wohlfarth, 1996) around 13.5 cal kyr BP, has not been used because of the little evidence for 
a comparably significant climatic oscillation between Allerød and Bølling warm phases outside of Northern Europe (Gray and Lowe, 1977), in principle justifying the usage of Bølling-Allerød as one continuous warm phase (interstadial). YD is a relative term distinguishing between a younger layer chronostratigraphically dated around 12 cal kyr BP and OD. Among these terms, YD is the most largely used.

The Bølling-Allerød Interstadial (BA), on the other hand, has been consistently described in tree-rings from Germany (Friedrich et al., 2001), marine sediments from Cariaco Basin (Hughen et al., 2000), stalagmites in Asia (e.g., Sinha et al., 2005; Cheng et al., 2013), $\mathrm{Mg} / \mathrm{Ca}$ in planktonic foraminifera from the western South Atlantic (Chiessi et al., 2008), ice cores from Greenland (e.g., Rasmussen et al., 2014; although in this record BA is referred to as DO-1), and the South American Andes (e.g., Thompson et al., 1998).

The BA is one of the most significant abrupt events of Termination I. One of the reasons relates to the major increase in atmospheric $\mathrm{CO}_{2}$ and $\mathrm{CH}_{4}$ concentrations, around 12 ppmv (parts per million per volume) and 150 ppbv (parts per billion per volume), respectively, within a time interval between 50 and 200 years (Marcott et al., 2014), and a sea-level rise of $\sim 20 \mathrm{~m}$ in less than 500 years, namely Melt Water Pulse 1A (MWP1A) (Deschamps et al., 2012).

The mechanisms that explain its occurrence remain unclear, but there have been indications that increased inflow of warm saline waters from the Indian Ocean entered the Atlantic via the Agulhas Leakage around 14.9 cal kyr BP (Chiessi et al., 2008), which may have contributed for the abrupt resumption of the AMOC and consequently for the warming in the NH (McManus et al., 2004). Further on, a study by Thiagarajan et al. (2014) showed evidence that a thermal inversion (warm waters under cold ones) developed in deep North Atlantic around $15 \mathrm{cal}$ kyr BP. This metastable thermal inversion was sustained by differential salinity content and may have stored heat in deep North Atlantic, triggering the rapid AMOC restart at the onset of BA as the built up warmth was released (Thiagarajan et al., 2014). In yet another hypothesis, Koehler et al. (2014) defend that a sudden decrease in atmospheric $\Delta^{14} \mathrm{C}$ around the onset of the BA indicates degassing of an extremely ${ }^{14} \mathrm{C}$-poor or even ${ }^{14} \mathrm{C}-$ free carbon source, possibly connected with thawing of extended areas of $\mathrm{NH}$ permafrost, would have led to the anomalous northern hemispheric warming during the BA. 
Whichever may have been the exact mechanism that led to the onset of the BA, it is widely accepted that it is synchronous with a rapid switch in AMOC strength (McManus et al., 2004; Koehler et al., 2014) and that the abrupt atmospheric warming together with oceanic reorganization had world wide impact, leading to a return to colder conditions in Antarctica (e.g., Weber et al., 2014), an abrupt warm phase in Bolivian Andes (Thompson et al., 1998) and, higher terrigenous input as well as relatively warmer SST in Cariaco Basin (Peterson et al., 2000; Lea et al., 2003). The latter changes in Cariaco Basin probably indicate a northward shift (comparing to HS1) of the ITCZ during the BA. This condition may have led to a weakening of the SAMS and drier than normal conditions in central and eastern South America (Catunda et al., in prep., see attached manuscript) 


\section{Study area, modern oceanography and climatology / Área de}

estudo, oceanografia e climatologia modernas

\subsection{Study area / Área de estudo}

The marine sediment cores selected for this project, GeoB3227-2 and GeoB3228-1 (Pätzold et al., 1996) (see section 4.1), were collected on the eastern Brazilian continental slope at the Espírito Santo Basin, southward of the Abrolhos Bank and Vitória-Trindade Ridge and close to the Doce River Canyon System (Schreiner et al., 2009). Continental slopes present the most unstable sedimentation areas in the oceans, favorable for the development of canyons and submarine incisions that serve as channels for the transport of terrigenous sediments from shallower areas and the continent to the deep ocean by turbidity currents (Heezen et al., 1959).

Eastern Brazil $\left(30^{\circ} \mathrm{S}\right.$ to $\left.15^{\circ} \mathrm{S}\right)$ is characterized by a mountainous landscape, bordered by narrow coastal plains, high rainfall, tropical vegetation, and relatively short coastal rivers, limiting the terrigenous input to the Eastern South American continental margin between La Plata and São Francisco rivers (Summerhayes et al., 1976; de Almeida et al., 1981).

The Doce River Basin (Figure 3.1) is an important medium sized drainage basin in eastern Brazilian coastal zone (Marques et al., 2004; de Oliveira et al., 2012) with area of $86.715 \mathrm{~km}^{2}$ (http://www.cbhdoce.org.br/; Souza and Knoppers, 2003) constituting the second largest drainage basin in eastern Brazil (after the São Francisco River Basin). The Doce River originates in the mountainous hinterland, over 1300m of altitude (i.e., Serra da Mantiqueira and Serra do Espinhaço) and throughout its $850 \mathrm{~km}$ course crosses the crystalline Precambrian basement, covered by a thick weathered mantle, and the Tertiary coastal iron-rich sediments of the Barreiras-Formation (Gunnell, 1998; Carmo and Vasconcelos, 2004). 


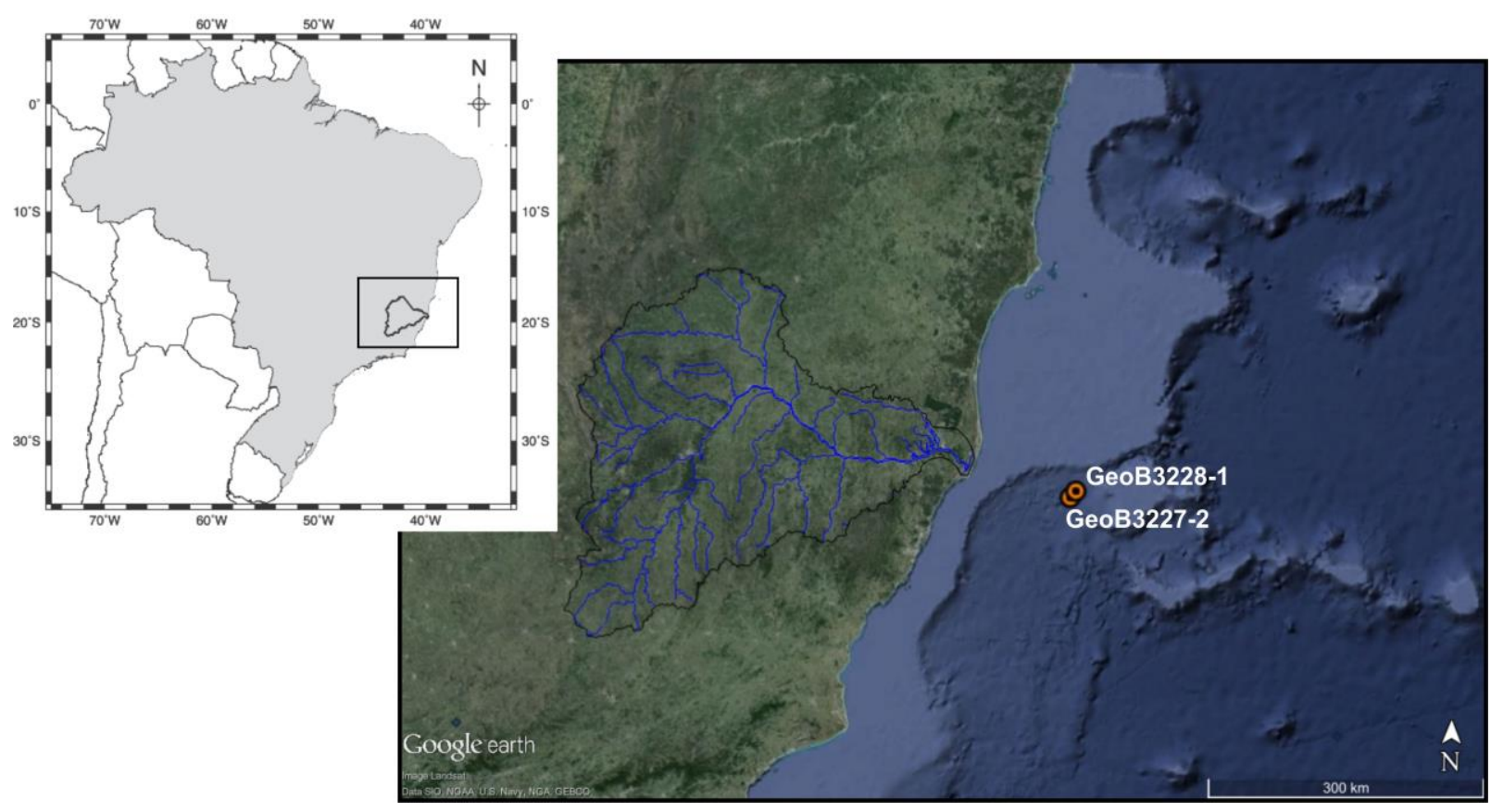

Figure 3.1: Location of the Doce River Basin (black line) and marine sediment cores GeoB3227-2 (1340 mbsl) and GeoB3228-1 (1095 mbsl). Figure prepared using a Landsat image and the software Google Earth with an approximate $800 \mathrm{~km}$ high view over Earth's surface. Doce River Basin and rivers (blue lines) provided by the Brazilian Geological Service (CPRM, http://geobank.cprm.gov.br/).

Terrigenous sediments at our marine core sites (Figures 3.1 and 3.2) have been directly delivered by the Doce River (Tintelnot, 1995; Tintelnot et al., 1998) during Late Pleistocene, when the river's mouth was located beyond the current shelf break, locally between 60 and 70 $\mathrm{m}$ water depth (Bastos et al., 2015). Under Pleistocene low sea-level conditions, the likely transport path for terrigenous sediment to the study site was via one of the incised valleys of the Doce River Canyon System (Brush et al., 2004; Schreiner et al., 2009; Maia, 2013; Figure 3.2). Connections between the river and these incised valleys have been previously suggested in the scientific literature (França, 1979; Alves, 1999; Maia, 2013; França et al., 2015). Furthermore, geochemical measurements at the mid-continental slope of the Abrolhos Bank and the Doce River shelf (Tintelnot, 1995; Massé et al., 1996) registered high kaolinite contents, connected with the eastern and southeastern Brazilian rivers' mineralogical signature, supporting our provenance hypothesis. 
The river's mouth forms the largest wave-influenced delta in the Brazilian coast, which progradated continuously through the late Pleistocene, dominated by fluvial processes. The delta formation kept pace with the deglacial rising sea level due to relatively high rainfall in the Doce River drainage basin and high amount of total suspended sediments transported by the river (Rossetti et al., 2015).

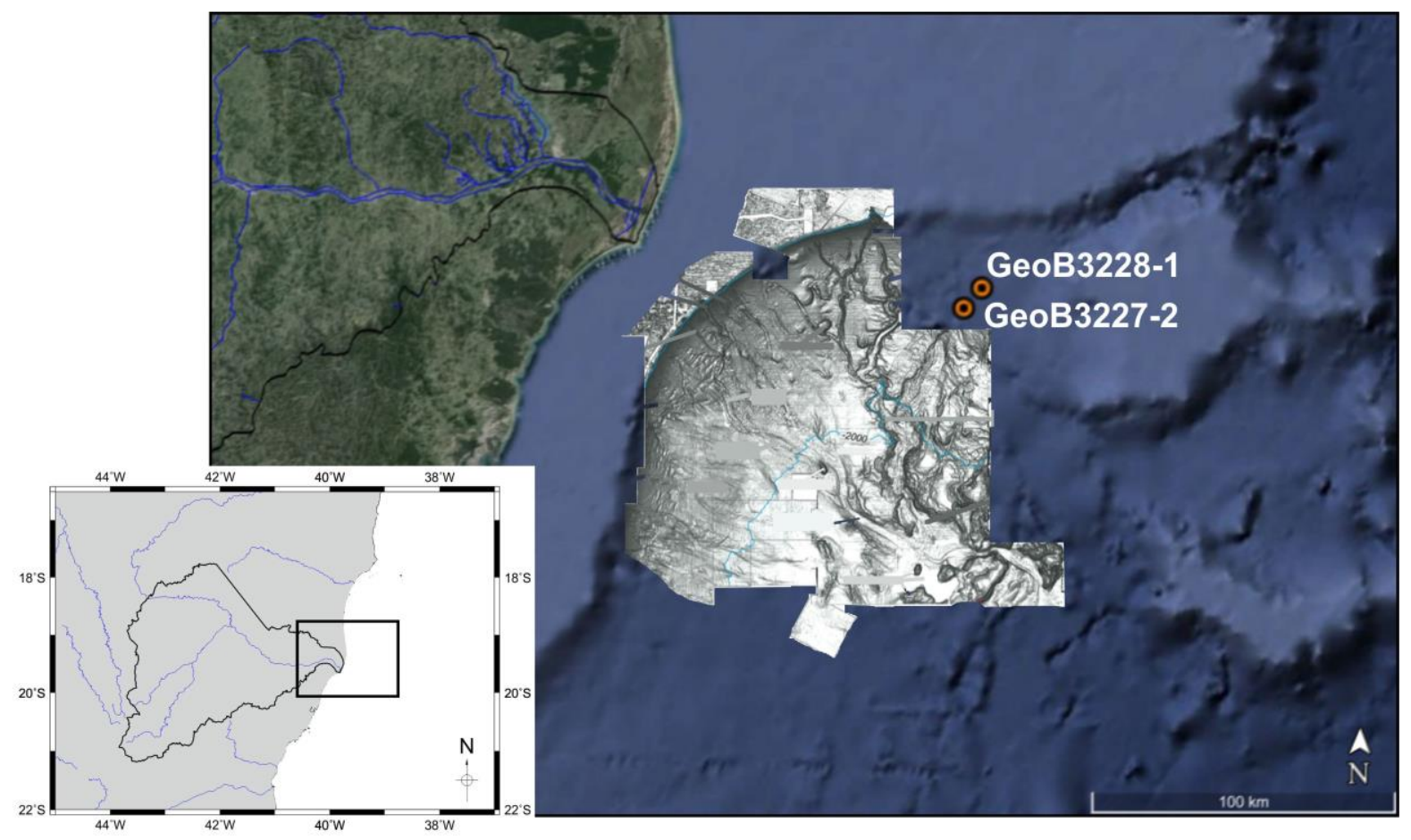

Figure 3.2: Doce River Canyon System and the location of marine sediment cores GeoB3228-1 and GeoB3227-2. Figure prepared using a Landsat image and the software Google Earth with an approximate $400 \mathrm{~km}$ high view over Earth's surface. Doce River Basin (black line) and rivers (blue lines) contours provided by the Brazilian Geological Service (CPRM, http://geobank.cprm.gov.br/). Digital model of sea floor adapted from Schreiner et al., 2009. 


\subsection{Modern oceanography of the western South Atlantic adjacent to the}

Doce River shelf / Oceanografia moderna do oeste do Atlântico Sul adjacente à plataforma do Rio Doce

The outer shelf and upper $600 \mathrm{~m}$ of the water column over the continental slope in the study area are occupied by the Brazil Current (BC). Starting around $10^{\circ} \mathrm{S}$ and flowing southward, BC is the western boundary current that closes the SSG (Figure 3.3). It originates at the bifurcation of the southern branch of South Equatorial Current, that also feeds the North Brazil Current (NBC; Stramma, 1991; Stramma and England, 1999). The BC starts as a relatively weak western boundary current transporting waters warmer than $20^{\circ} \mathrm{C}$ and more saline than 36 psu, namely Tropical Surface Water (TSW), increasing its transport volume southwards as the South Atlantic Central Water (SACW) reinforces the southward flow (Emílsson, 1961; Peterson and Stramma, 1991; Stramma and England, 1999; da Silveira et al., 2000). The latter, is located just below the mixed layer (that has its lower limit around $70 \mathrm{~m}$ ), and is described by a straight line between $20^{\circ} \mathrm{C}, 36$ psu and $5^{\circ} \mathrm{C}, 34.3 \mathrm{psu}$ in T-S diagrams (Figure 3.4; Stramma and England, 1999). Although SACW mainly originates in the SSG, it also receives contribution from the south Indian Ocean by Agulhas Current intrusions (Stramma and England, 1999). Only the upper ca. $100 \mathrm{~m}$ of the water column are affected by seasonally varying temperatures and salinities in the western tropical South Atlantic (Peterson and Stramma, 1991).

The interaction of the BC, the morphological barrier of the broad and shallow Abrolhos Bank and the Vitória-Trindade Ridge characterize the surface hydrography in the study area. In April 1982, Evans et al. (1983) collected data showing that the BC flowed continuously through the passage closest to the coast and continued in a confined and organized way over the continental slope. That view was adopted in the works of several following authors, including Peterson and Stramma (1991). However, data from surface drifters revealed the unexpected oceanographic complexity of the region, that is strongly affected by the temporal occurrence and migration of the Vitória Eddy (Schmid et al., 1995). It was then confirmed that the surface temperatures and productivity on the shelf edge are affected by upwelling of SACW during austral summer, as previously suggested by Summerhayes et al. (1976). Consequently, the Doce River shelf presents special conditions, where local land input and upwelling of relatively nutrient-rich SACW at the shelf edge are significant factors 
influencing the local sedimentation and primary production (Summerhayes et al., 1976; Ekau and Knoppers, 1996; Knoppers et al., 1999).

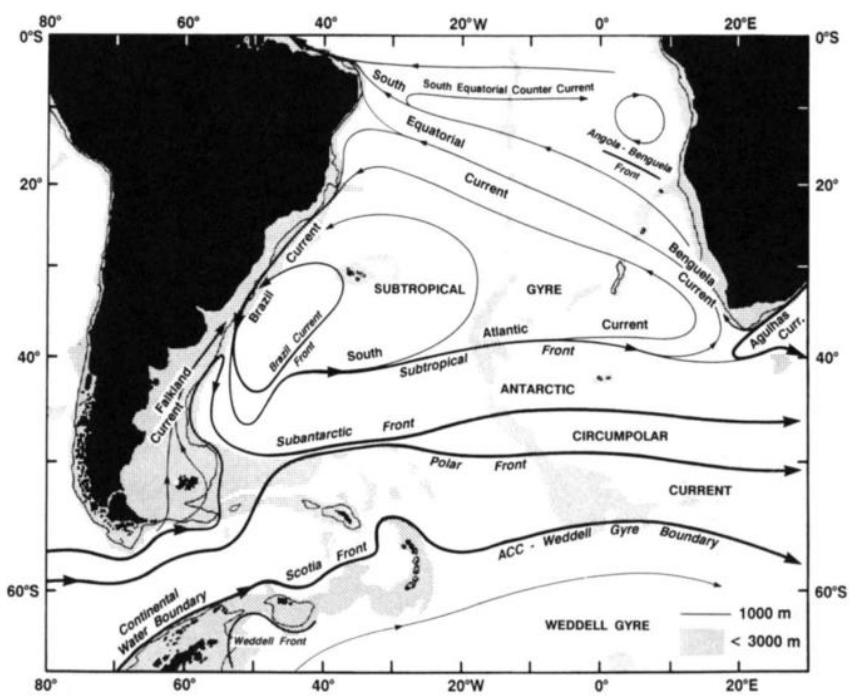

Figure 3.3: (Above) Schematic representation of the large-scale, upper level geostrophic currents and fronts in the South Atlantic Ocean. Figure extracted from Peterson and Stramma, 1991. (Right) Location of the Doce River Basin and schematic representation of the currents directly affecting the Brazilian coast. Currents are represented by their acronyms: BC, Brazil Current; BCC, Brazilian coastal current; NBC, North Brazil Current. Numbers 1 and 2 represent marine sediment cores GeoB3228-1 and GeoB3227-2, respectively.
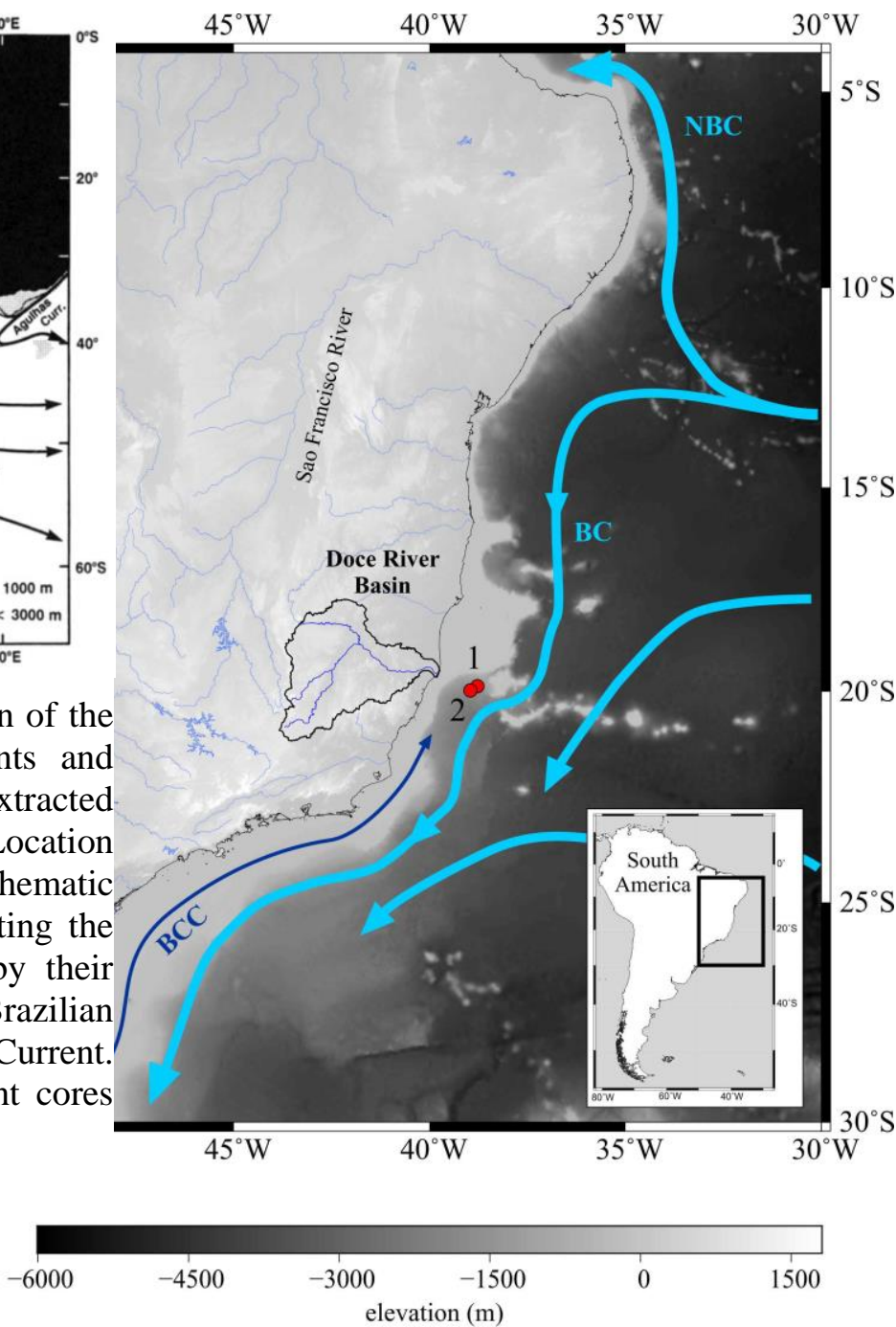

Below SACW, at intermediate depths (i.e., 500 to $1500 \mathrm{~m}$ ), the Intermediate Western Boundary Current transports AAIW and the underlying UCDW equatorwards (Figure 3.4; Tsuchiya and Talley, 1994; Schmid et al., 1995; da Silveira et al., 2004). Compared with AAIW, SACW is warm and salty (Stramma and England, 1999). AAIW is formed in the Subantarctic Frontal Zone (Talley, 1996) from a surface region of the circumpolar layer and its characteristic relative oxygen maximum and salinity minimum were found in the study area at 800m water depth (Tsuchiya and Talley, 1994; Locarnini et al., 2013). Below AAIW, UCDW is defined by its very low oxygen content and can be recognized as an oxygen minimum tongue lying just under the relatively well oxygenated AAIW (Tsuchiya and Talley, 
1994). UCDW's relative potential temperature minimum and oxygen minimum were found around $1100 \mathrm{~m}$.

At greater depths, the western tropical South Atlantic is filled by the southward flowing North Atlantic Deep Water (NADW) between ca. 1500 and $3000 \mathrm{~m}$ water depth, and two southern sourced northward flowing water masses, namely Lower Circumpolar Deep Water (LCDW) between ca. 3000 and 3500 m water depth, and Antarctic Bottom Water (AABW) present between ca. $3500 \mathrm{~m}$ water depth and the bottom of the ocean (Stramma and England, 1999). While NADW shows relatively high salinities, low nutrient content and high oxygen values, AAIW and UCDW are relatively fresh, show high nutrient content and low oxygen values (Figure 3.4).

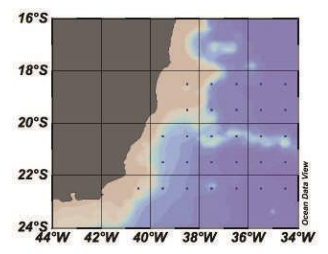

a
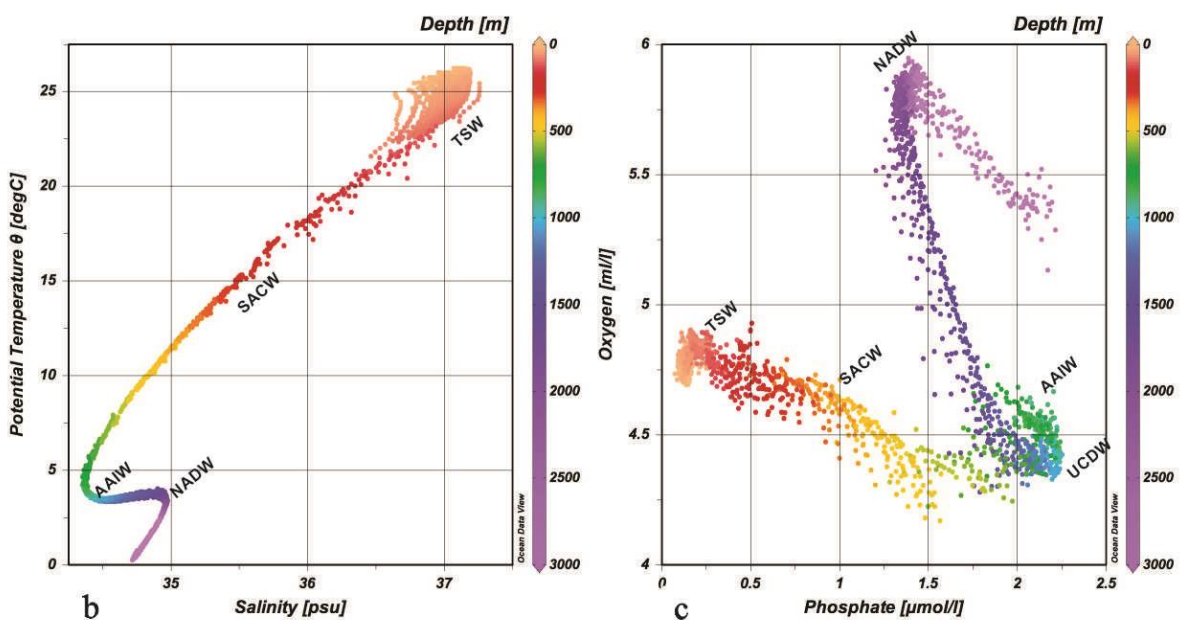

Figure 3.4: Properties of the water column in the study area. (a) Location of the interpolated data stations, (b) potential temperature-salinity diagram, (c) oxygen-phosphate diagram. Both panels (b and c) were plotted based on World Ocean Atlas 2013 data from $18^{\circ} \mathrm{S}$ to $23^{\circ} \mathrm{S}$, from the Brazilian coast to $36^{\circ} \mathrm{W}$, and from 0 to $3000 \mathrm{~m}$ water depth, as shown in the inset map (a). Water masses are labeled by their acronyms: AAIW - Antarctic Intermediate Water, NADW - North Atlantic Deep Water, SACW - South Atlantic Central Water, TSW - Tropical Surface Water, and UCDW - Upper Circumpolar Deep Water. Long-term mean annual data from World Ocean Atlas 2013 (Locarnini et al., 2013, Zweng et al., 2013, Garcia et al., 2013a and 2013b) and plotted using the software Ocean Data View 4 (Schlitzer, 2015). 


\subsection{Modern climatology of Doce River basin / Climatologia moderna da Bacia do Rio Doce}

The Doce River basin is located in a hot and humid tropical climate region with distinct rainy summer and dry fall-winter seasons (i.e., Cwb, Cwa and Aw, Köppen-Geiger climate types; Peel et al., 2007). This seasonality is due to SASM and SACZ activity, fed by moisture from the ITCZ (see section 2.1.2). The average precipitation in the basin is $1400 \mathrm{~mm} / \mathrm{a}$ with at least $80 \%$ of the rain falling during the rainy season (October to March; Figure 3.5). Exceptionally, in areas close to the coast, rains are distributed throughout the year, with austral winter rainfall brought by extratropical cyclones during the winter (Garreaud et al., 2009). The river discharge is also the second largest of the Brazilian eastern coast and is strongly seasonal, following the rainfall pattern. The river's runoff averages at $900 \mathrm{~m}^{3} / \mathrm{s}$, varying from $500 \mathrm{~m}^{3} / \mathrm{s}$, from May to October, to $1300 \mathrm{~m}^{3} / \mathrm{s}$, from November to April (www2.ana.gov.br; runoff measurements from the Colatina Water Station, located $90 \mathrm{~km}$ from the river mouth). Table 3.1 provides details about the selected locations for which precipitation histograms are shown in Figure 3.5.

Table 3.1. Data from the selected monitoring stations for which histograms are shown in Figure 3.5. ANA - Brazilian Portuguese acronym for National Waters Agency.

\begin{tabular}{ccccc}
\hline & ANA code & $\begin{array}{c}\text { Nearest } \\
\text { city, state }\end{array}$ & $\begin{array}{c}\text { Monitored } \\
\text { period }\end{array}$ & $\begin{array}{c}\text { Location within } \\
\text { the basin }\end{array}$ \\
\hline \hline a & 1842004 & $\begin{array}{c}\text { São Pedro } \\
\text { do Suaçui, } \\
\text { MG }\end{array}$ & $1941-2015$ & north \\
b & 1939002 & Linhares, ES & $1974-2015$ & east \\
c & 2043010 & Piranga, MG & $1941-2005$ & south \\
d & 1942008 & $\begin{array}{c}\text { Dom Cavati, } \\
\text { MG }\end{array}$ & $1969-2005$ & center \\
e & 56994500 & Colatina, ES & $1939-2014$ & $\begin{array}{c}\text { 90 km inland } \\
\text { from river mouth }\end{array}$ \\
\hline \hline
\end{tabular}




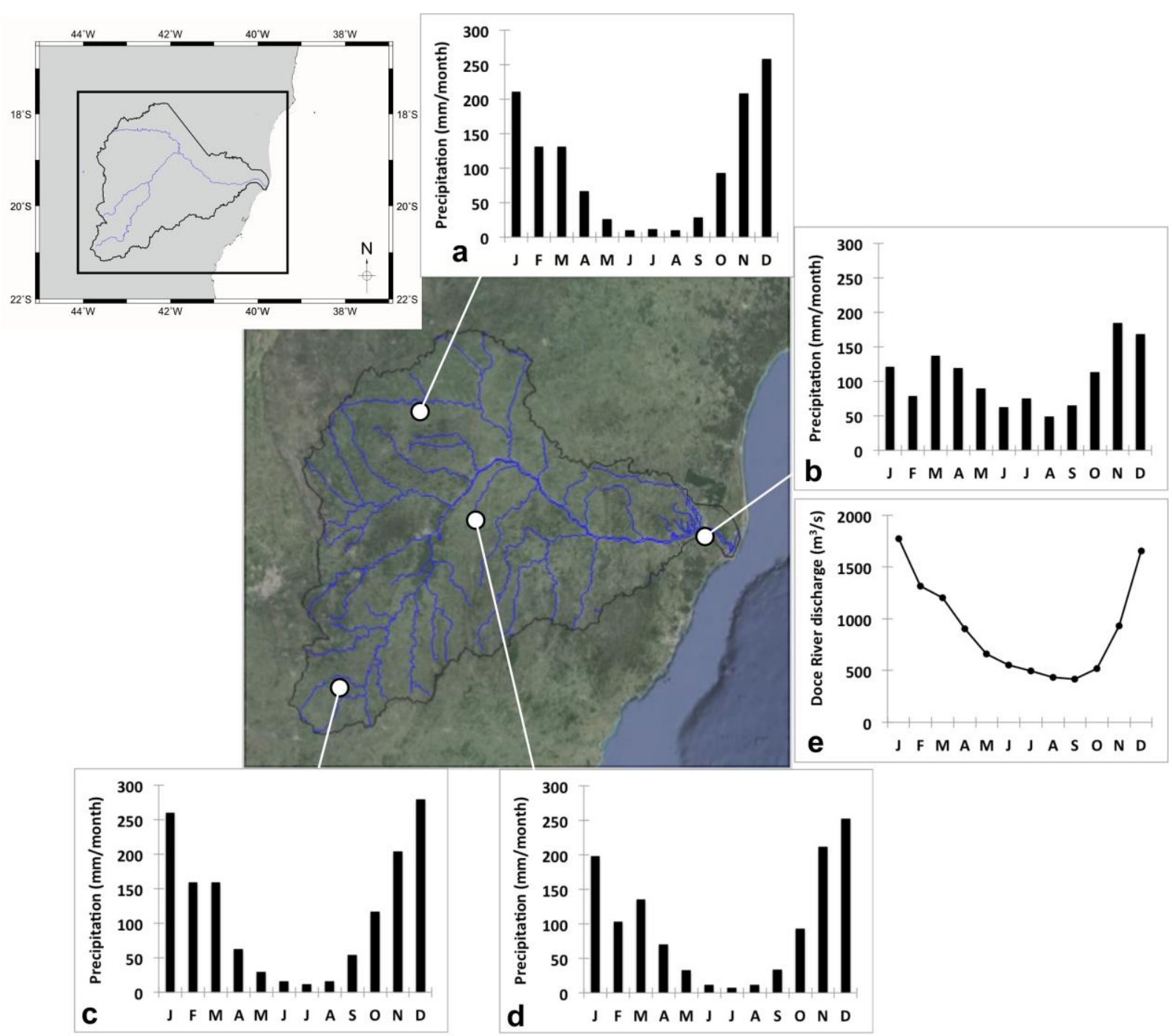

Figure 3.5: Histograms of monthly precipitation at selected stations (panels $\mathbf{a}, \mathbf{b}, \mathbf{c}$ and $\mathbf{d}$ ) from the Doce River drainage basin (www2.ana.gov.br), and mean annual cycle of the Doce River discharge (panel e, www2.ana.gov.br). See Table 3.1 for more details about the selected locations. 


\section{Materials and methods / Materiais e métodos}

\subsection{Materials - Marine sediment cores / Materiais - Testemunhos sedimentares marinhos}

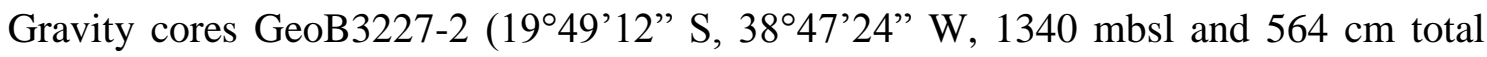
length) and GeoB3228-1 (1945’36” S, 38 45’36” W, 1095 mbsl and $567 \mathrm{~cm}$ total length) were retrieved from the Brazilian continental slope during RV Victor Hensen cruise JOPS II, leg 8 (Pätzold et al., 1996). The core sites are located $105 \mathrm{~km}$ from the modern Brazilian coastline and $110 \mathrm{~km}$ of the current mouth of the Doce River, at the Espírito Santo Basin. The gravity cores were stored at $4^{\circ} \mathrm{C}$ under controlled humidity in the GeoB Core Repository, MARUM - Center for Marine Environmental Sciences, University of Bremen, Germany.

\subsection{Methods / Métodos}

\subsubsection{Marine sediment cores visual evaluation, sampling and sample processing /}

Avaliação visual dos testemunhos de sedimento marinho, amostragem e processamento das amostras

Gravity core GeoB3227-2, $564 \mathrm{~cm}$ long, is composed of olive gray clay and mud. Exceptionally, between depths $56 \mathrm{~cm}$ and $233 \mathrm{~cm}$ the sediment is reddish brown. Gravity core GeoB3228-1 presents similar characteristics to GeoB3227-2. It is constituted mostly of olive gray mud with a reddish brown layer between $66 \mathrm{~cm}$ and $150 \mathrm{~cm}$ (Figure 4.1).

Marine sediment core GeoB3228-1 was sampled for isotopic analyses every two centimeters (276 samples in total) with $10 \mathrm{ml}$ syringes, labelled, weighted while wet, packed and brought to the Paleoceanography and Paleoclimatology Laboratory $\left(\mathrm{P}^{2} \mathrm{~L}\right)$ at the School of Arts, Sciences and Humanities of the University of São Paulo, Brazil.

The sample's preparation for benthic foraminifera selection was executed in the $\mathrm{P}^{2} \mathrm{~L}$, and consisted in drying $\left(50^{\circ} \mathrm{C}\right.$ maximum oven temperature), weighting the dry samples to calculate water content, soaking in a beaker with water overnight, wet sieving over $>125 \mu \mathrm{m}$ and $>63 \mu \mathrm{m}$ combined meshes, rinsing both fractions with Milli-Q water and final drying $\left(50^{\circ} \mathrm{C}\right.$ maximum oven temperature) of the residues. After these steps, both fractions ( $>125 \mu \mathrm{m}$ and between $125 \mu \mathrm{m}$ and $63 \mu \mathrm{m}$ ) were stored in glass vials, labeled, and weighted. 


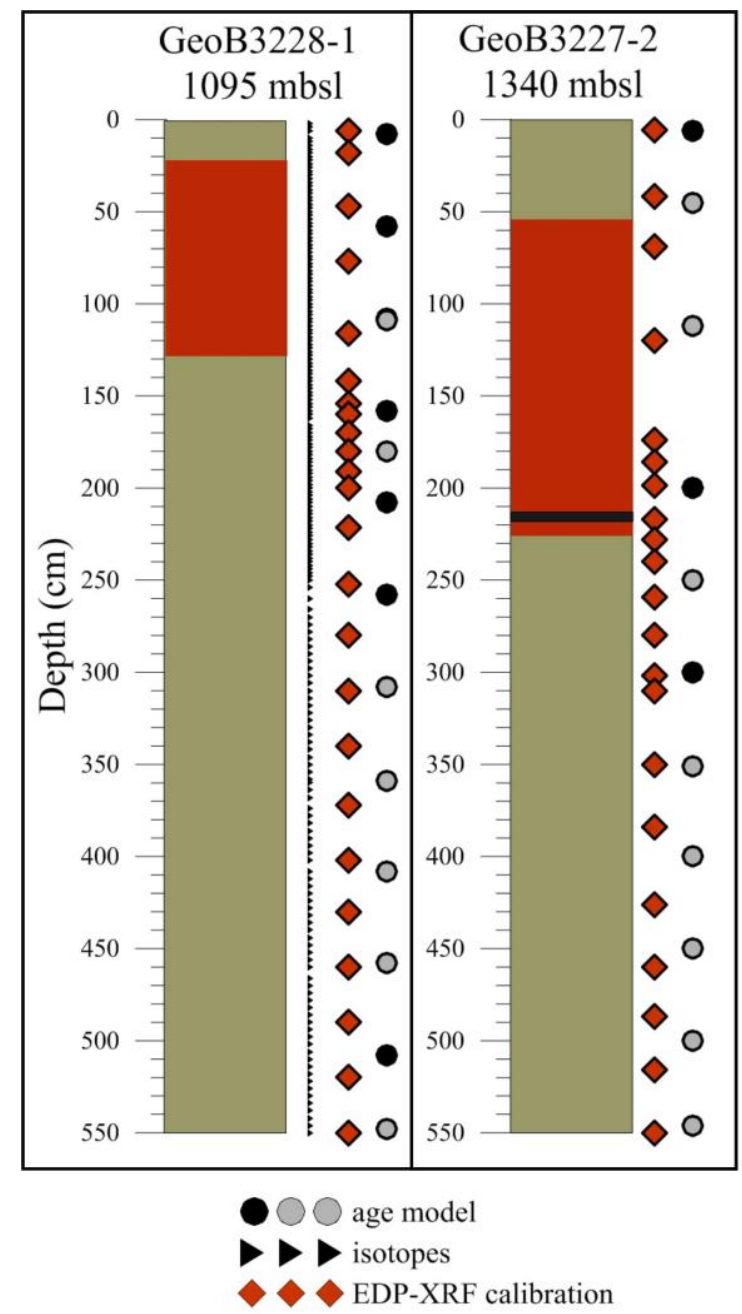

Figure 4.1. General color and sampling schematics of marine sediment cores GeoB3228-1 and GeoB3227-2.

The sample's preparation for calibration of the element intensities was executed in laboratories from the University of Bremen, Germany. At the MARUM - Center for Marine Environmental Sciences, 24 samples from GeoB3228-1 and 21 samples from GeoB3227-2 were selected and taken with cut syringes to be analyzed via Energy Dispersive X-Ray Fluorescence (EDP-XRF). Samples were spaced $25 \mathrm{~cm}$ on average, but a smaller value was chosen for a better representation of core sections that showed distinct features on a $\mathrm{Fe} / \mathrm{Ca}$ versus depth plot. The 45 samples were freeze-dried, powdered and homogenized with an agate mortar. 


\subsubsection{AMS radiocarbon dating and age models / Datações radiocarbônicas AMS e}

modelos de idade

Radiocarbon analyses were used to establish accurate age models for the sediment cores selected for this dissertation. With this purpose, one AMS ${ }^{14} \mathrm{C}$ dating was performed approximately every $50 \mathrm{~cm}$ for each marine sediment core.

Three AMS ${ }^{14} \mathrm{C}$ ages obtained at 6,200 and $300 \mathrm{~cm}$ core depths of core GeoB3227-2 were already available (Chiessi et al., unpublished data; Table 5.1, section 5.1). Similarly, seven AMS ${ }^{14} \mathrm{C}$ ages at 8, 58, 108, 158, 208, 258 and $508 \mathrm{~cm}$ core depths of core GeoB3228-1 were also available (Chiessi et al., unpublished data; Table 5.1, section 5.1).

For this project, 15 samples were chosen to produce detailed age models for both gravity cores. After sample preparation, 10mg of Globiogerinoides ruber tests (around 600 tests) of each sample were selected for AMS ${ }^{14} \mathrm{C}$ dating from the $>125 \mu \mathrm{m}$ fraction using 25 50X magnification under a binocular microscope. For those cases where not enough $G$. ruber specimens were available, the sample was complemented with Globigerinoides sacculifer. When both species were not enough to reach the desired mass, the amount was completed with other planktic species, avoiding deep-dwellers such as Globorotalia truncatulinoides. The 15 samples were then sent for analyses via AMS at BETA Analytic Laboratory, Miami, USA.

The raw radiocarbon ages were calibrated for the reservatory effect (Franke et al., 2008) and for variations on the original ${ }^{14} \mathrm{C}$ concentration in the atmosphere (Reimer et al., 2013). For this calibration we used software Calib 7.0.2 (Stuiver and Reimer, 1993) and the Marine13 calibration curve (Reimer et al., 2013). Age models were produced based on the linear interpolation of the calibrated ages.

\subsubsection{Benthic foraminifera selection strategy / Estratégia para seleção de foraminíferos bentônicos}

Before starting the systematic picking of benthic foraminifera for $\delta^{13} \mathrm{C}$ and $\delta^{18} \mathrm{O}$ analyses, a preliminary selection of Cibicidoides/Cibicides and Uvigerina genera was performed to assess the species availability within the first half of GeoB3228-1. The search was conducted to evaluate if there was any unique species of these genera that would be present throughout the Holocene and Termination I sections of the core, established using the 
preliminary age model available. The results of this preliminary search are shown in Table 4.1 .

Table 4.1 Results of the preliminary selection of benthic foraminifera from core GeoB3228-1, considering the genera Cibicidoides/Cibicides and Uvigerina (orange and blue background show the Holocene and Termination I, respectively). Number of specimens per sample.

\begin{tabular}{|c|c|c|c|c|c|c|c|}
\hline Genera/ species & Depth (cm) & 2 & 40 & 82 & 112 & 232 & 250 \\
\cline { 2 - 7 } & Age (cal kyr BP) & 2.9 & 5.2 & 7.7 & 9.5 & 19.5 & 20.3 \\
\hline Cibicidoides/Cibicides & 2 & 1 & - & 1 & - & - \\
Cibicides wuellerstorfi & - & - & 3 & - & - & 1 \\
Cibicides pachyderma & 1 & - & - & - & 1 & - \\
Cibicidoides cicatricosus & 3 & - & - & - & - & - \\
Cibicidoides robertsonianus & 1 & 1 & - & 1 & - & - \\
Cibicidoides mundulus & 3 & 4 & 3 & 3 & - & - \\
Cibicidoides subhaidingerii & & & & & & \\
& & & & & & \\
Uvigerina & 12 & 14 & 7 & 6 & 8 & 8 \\
Uvigerina peregrina & - & 5 & - & 1 & 1 & - \\
Uvigerina aculeata & 2 & 5 & 2 & - & 1 & 1 \\
Uvigerina pigmea &
\end{tabular}

The only consistently found species was Uvigerina peregrina (Cushman, 1923) and no single Cibicidoides or Cibicides species was present on all samples. From these latter genera, the following species were found (from the more abundant to the less abundant): Cibicidoides subhaidingerii (Parr, 1950), Cibicides pachyderma (Rzehak, 1886) and Cibicides wuellerstorfi (Schwager, 1866). Thus, U. peregrina and Cibicidoides spp. (a mixture among Cibicides and/or Cibicidoides specimes present at each sample) specimens were picked separately.

Microfossil slides were used to store three to eight tests of $U$. peregrina or Cibicidoides spp. Each test was over $0.3 \mathrm{~mm}$ and picked from the $>125 \mu \mathrm{m}$ fraction using $25-50 \mathrm{X}$ magnification under a binocular microscope. On eventual samples where the Cibicidoides and/or Cibicides genera were abundant, three to five tests of individual species were picked. This aimed to perform a comparison between Cibicidoides spp. isotopic values and species specific isotopic offsets available in the scientific literature (e.g., Fontanier et al., 2006).

In total 441 samples of benthic foraminifera were picked along GeoB3228-1's full extension. 


\subsection{4. $\boldsymbol{\delta}^{\mathbf{1 8}} \mathbf{O}$ and $\boldsymbol{\delta}^{\mathbf{1 3}} \mathbf{C}$ of benthic foraminifera $/ \delta^{18} O$ e $\delta^{13} \mathrm{C}$ de foraminíferos bentônicos}

Oxygen and carbon stable isotopes are traditional paleooceanographic proxies used for reconstituting physical and chemical characteristics of water masses and ocean circulation. $\delta^{18} \mathrm{O}$ in marine carbonates is presently widely applied for assessing past variability in ocean circulation (e.g., Lynch-Stieglitz et al., 2006), continental ice volume (e.g., Waelbroeck et al., 2002), ocean water salinity (e.g., Adkins et al., 2002; Weldeab et al., 2006) and, paired with $\mathrm{Mg} / \mathrm{Ca}$, temperature (e.g., Emiliani, 1955; Waelbroeck et al., 2002). $\delta^{13} \mathrm{C}$ of foraminiferal calcite provide a wealth of information on the carbon cycling of the oceans, and has been used to infer the distribution of deep water masses and their geographic and bathymetric distributions (e.g., Curry and Oppo, 2005), but also for variations of biological productivity and variations in the global carbon cycle (e.g., Duplessy et al., 1988).

Isotopic ratios of stable isotopes are a measurement of fractionation processes. The isotopic composition of a sample is expressed using the $\delta$ notation (i.e., $\delta^{18} \mathrm{O}$ and $\delta^{13} \mathrm{C}$ ), which represents the difference between the ratio of the least over the most abundant isotope of a sample and an internationally recognized standard, expressed in parts per thousand (i.e., \%o). Equation 1 exemplifies the calculation of $\delta^{18} \mathrm{O}$.

Equation 1:

$$
\delta^{18} O_{\text {sample }}=\left[\frac{\left({ }^{18} O /{ }^{16} O\right)_{\text {sample }}-\left({ }^{18} O /{ }^{16} O\right)_{\text {standard }}}{\left({ }^{18} O /{ }^{16} O\right)_{\text {standard }}}\right] \times 10^{3}
$$

, which can be written as:

$$
\delta^{18} O_{\text {sample }}=\left[\frac{\left({ }^{18} O /{ }^{16} O\right)_{\text {sample }}}{\left({ }^{18} O /{ }^{16} O\right)_{\text {standard }}}-1\right] \times 10^{3}
$$

For carbonate isotopic ratios the most used standard is Vienna Pee Dee Belemnite (VPDB), normalized in relationship to the chemical composition of Belemnitella americana fossil shells from the cretaceous Pee Dee Formation in the United States and provided by the International Atomic Energy Agency in Vienna, Austria. 
The oxygen isotopic composition in marine carbonates varies both with temperature and the isotopic composition of seawater, which is in turn dependent on the global ice volume and correlated with local salinity (Waelbroeck et al., 2002; Mulitza et al., 2003). Surface $\delta^{18} \mathrm{O}_{\mathrm{w}}$ is generally positively correlated to salinity because both parameters are largely controlled by evaporation and precipitation (Craig and Gordon, 1965). Although the relationship between salinity, temperature and foraminiferal $\delta^{18} \mathrm{O}$ is relatively well understood, the latter cannot be used as a directly proportionate proxy for either temperature or salinity because both affect $\delta^{18} \mathrm{O}$ in opposite directions and, therefore, tend to cancel each other out (Curry and Oppo, 2005). Still, the equilibrium calcite $\delta^{18} \mathrm{O}$ values of water masses originating in the South Atlantic is generally higher at every water depth and denser than water masses originating in the North Atlantic because the difference in temperature dominates the equilibrium $\delta^{18} \mathrm{O}$ values (Curry and Oppo, 2005). $\delta^{18} \mathrm{O}$ in benthic foraminifera is a valuable deep water tracer, which values reflect conservative sea water properties and, assuming negligible geothermal and pressure heating effects, can only change due to mixing between water masses (e.g., Oppo et al., 2015).

A wide variety of factors affect seawater carbon composition (e.g., biological productivity and global carbon cycle) and its isotopic incorporation in foraminiferal calcite (e.g., species specific vital effects). Despite of that, $\delta^{13} \mathrm{C}$ is a useful proxy as water mass tracer because it is characteristic of its formation and can only be altered by mixing with water masses of another $\delta^{13} \mathrm{C}$ composition, by the oxidation of low $-\delta^{13} \mathrm{C}$ organic matter or "aging" (Curry and Lohmann, 1982; Kroopnick, 1985; Curry and Oppo, 2005).

Foraminifera use marine total dissolved inorganic carbon (DIC) to precipitate their calcite tests, recording $\delta^{13} \mathrm{C}$ of seawater. DIC comprises the sum of the concentrations of $\mathrm{CO}_{2}$ (aqueous carbon dioxide), $\mathrm{HCO}^{3-}$ (bicarbonate), and $\mathrm{CO}_{3}{ }^{2-}$ (carbonate ion), and seawater $\mathrm{pH}$ controls the relative proportion of the different components (Kroopnick, 1985). Biological primary production in the euphotic zone, when producers take up nutrients and carbon (photosynthesis), strongly fractionates stable carbon isotopes concentrating the light isotope ${ }^{12} \mathrm{C}$ in organic matter, and enriching superficial water in ${ }^{13} \mathrm{C}$ (Freeman and Hayes, 1992), as recorded by shallow dwelling planktonic foraminifera. Deeper in the water column, the ${ }^{12} \mathrm{C}$ rich organic matter is oxidized and remineralized, adding nutrients, and carbon with low ${ }^{13} \mathrm{C} /{ }^{12} \mathrm{C}$, to deep waters (Duplessy et al., 1984). As a result of these processes, nutrients and 
$\delta^{13} \mathrm{C}$ of DIC are generally negatively correlated, and nutrient-rich southern sourced water masses like AAIW, CDW and AABW have relatively low $\delta^{13} \mathrm{C}$ values, while nutrient-poor NADW shows high $\delta^{13} \mathrm{C}$ values (Kroopnick, 1985). High nutrient concentrations and low $\delta^{13} \mathrm{C}$ in $\mathrm{AABW}$, for example, reflect the longer time these waters have spent away from the surface, collecting nutrients and ${ }^{13} \mathrm{C}$-poor carbon from the decay of organic matter transported to abyssal depths in particulate and dissolved forms.

The $\delta^{13} \mathrm{C}$ in surface waters is also influenced by air-sea gas exchange, which is favored in cold, windy regions (Broecker and Maier Reimer, 1992), such as the Subantarctic Frontal Zone. ${ }^{13} \mathrm{C}$ enrichment of dissolved $\mathrm{CO}_{2}$ in surface seawater results from the temperaturedependent fractionation of ${ }^{13} \mathrm{C} /{ }^{12} \mathrm{C}$ during the exchange of $\mathrm{CO}_{2}$ at the water atmosphere interface (Mook et al., 1974). Colder waters display a larger fractionation and higher $\delta^{13} \mathrm{C}$ values for DIC. Gas exchange rates also depend on wind mixing in the surface ocean with stronger winds allowing the $\delta^{13} \mathrm{C}$ of DIC in seawater to equilibrate with the atmosphere. Owing to substantial exchange of $\mathrm{CO}_{2}$ between the atmosphere and the cold surface waters of the Southern Ocean, the present-day AAIW, for instance, is more enriched in $\delta^{13} \mathrm{C}$ by $\sim 1 \%$ than would be expected on the basis of its nutrient content and biological productivity (Ninnemann and Charles, 1997; Ninnemann and Charles, 2002).

The applicability of $\delta^{13} \mathrm{C}$ of benthic foraminifera is relatively limited by the scarce knowledge about the complex effects of ecological, biogeochemical and physical parameters. Therefore, the comparison of the $\delta^{13} \mathrm{C}$ signal of different species should consider differences in metabolism and calcification rate of the organisms, namely species-specific vital effects. In addition, the $\delta^{13} \mathrm{C}$ composition of the test carbonate varies with the microhabitat of different species reflecting $\delta^{13} \mathrm{C}$ gradients of DIC in the pore water (Schmiedl and Mackensen, 2006).

Species-specific vital effects in the $\delta^{13} \mathrm{C}$ signal are caused by differential incorporation of ${ }^{13} \mathrm{C}$-depleted metabolic $\mathrm{CO}_{2}$ into the test carbonate (e.g., Erez, 1978). Epifaunal taxa commonly calcify close to the isotopic signature of bottom water $\delta^{13} \mathrm{C}_{\mathrm{DIC}}$, whereas infaunal taxa bear a pore water signal which is marked by ${ }^{13} \mathrm{C}$ depletion (Corliss, 1985; Fontanier et al., 2006). Among genera of benthic foraminifera, the epifaunal Cibicidoides and Planulina seem to record the bottom water $\delta^{13} C_{\text {DIC }}$ most reliably (Duplessy et al., 1984; Schmiedl and Mackensen, 2006), although negative deviations in the $\delta^{13} \mathrm{C}$ values are possible as response to phytodetritus pulses in regions of very high productivity (Mackensen et al., 1993). 
The infaunal Uvigerina peregrina preferentially occupies the uppermost surface centimeter, and commonly approaches precipitation in equilibrium with $\delta^{18} \mathrm{O}$ (e.g., Schmiedl et al., 2004), allowing its use as substitute for the Cibicidoides genera. According to (Schmiedl and Mackensen, 2006) average metabolic effects amount to $-0.6 \%$ for Cibicidoides wuellerstorfi and $0.0 \%$ for Uvigerina peregrina in relationship with bottom waters $\delta^{18} \mathrm{O}$.

The assessment of metabolic effects in the $\delta^{13} \mathrm{C}$ signal of taxa from different microhabitats on and within the sediment is hampered by the dominance of environmental factors including gradients between $\delta^{13} \mathrm{C}_{\mathrm{DIC}}$ and $\mathrm{CO}_{3}{ }^{2-}$ in pore water and near-surface sediment, controlled by remineralization of organic matter (McCorkle et al., 1990; Schmiedl et al., 2004). Schmiedl and Mackensen (2006) calculated the $\delta^{13} \mathrm{C}$ differences between epifauna $(C$. wuellerstorfi) and shallow infauna (U. peregrina) between 0.16 and $1.35 \%$ in the Arabian Sea and interpreted them as changes in organic carbon $\left(\mathrm{C}_{\text {org }}\right)$ oxidation rates of bottom waters. Also, in that study, intervals of maximum deepwater oxygenation coincided with high benthic foraminiferal diversity and were interpreted as increased admixture of welloxygenated deepwater masses close to the ocean floor.

The 441 samples stored in microfossil slides were sent for $\delta^{18} \mathrm{O}$ and $\delta^{13} \mathrm{C}$ analysis at the Stable Isotopes Laboratory at the MARUM - Center for Marine Environmental Sciences, University of Bremen, Germany.

Stable carbon and oxygen isotope ratios were measured on a Finnigan MAT 253 gas isotope ratio mass spectrometer with Kiel IV automated carbonate preparation device. The instrument was calibrated using the in house standard (Solnhofen limestone), itself calibrated against the NBS 18 and NBS 19 standard reference materials. Standards and replicate analyses are performed to avoid drift in the machine and bias in the results through contamination as well as to assess the machine precision and accuracy. The data are reported in the usual delta-notation against Vienna-PDB. The standard deviations (reproducibility) for repeated measurements of the in house standard were $0.03 \%$ for $\delta^{13} \mathrm{C}$ and $0.07 \%$ for $\delta^{18} \mathrm{O}$.

Ice volume corrections were done for our Cibicidoides spp. $\delta^{18} \mathrm{O}\left(\delta^{18} \mathrm{O}_{c}\right)$ and $U$. peregrina $\delta^{18} \mathrm{O}\left(\delta^{18} \mathrm{O}_{\mathrm{u}}\right)$ records (corrected records shown only on the discussion, subsection 6.2). Corrections were calculated considering $1.00 \%$ as the global average change in $\delta^{18} \mathrm{O}$ of 
seawater due to ice volume (Schrag et al., 2002) distributed in time according to the (Lambeck and Chappell, 2001, updated in 2007) relative sea level data.

\subsubsection{Fe/Ca and Ti/Ca ratios in oceanic basins as paleoclimatological proxies / Razões}

$\mathrm{Fe} / \mathrm{Ca}$ e Ti/Ca como indicadores paleoclimáticos

Terrigenous materials deposited off the tropical and subtropical Atlantic South American coast are delivered to the ocean via fluvial pathways, which are highly sensitive to climate change. High concentrations of terrigenous elements and low Ca concentrations along the tropical and subtropical South American and African continental margins reflect the dominance of terrigenous input in these regions (Govin et al., 2012). A number of studies have used major element composition of marine sediment cores to trace changes in terrigenous input into the Atlantic. In the last decade, the number of studies focusing on the South American Margin increased significantly (Arz et al., 1998; Arz et al., 1999; Peterson et al., 2000; Haug et al., 2001; Jaeschke et al., 2007; Chiessi et al., 2010). Yet, the 23-7 S sector of the Brazilian continental margin remains completely void of studies. This is a particularly relevant sector of the continental margin for reconstructing the strength of the SACZ and the SASM (see section 2.1.2).

The late advances of this field come as a result of the relatively recent development of X-ray fluorescence (XRF) core scanners that can obtain nondestructive, almost continuous and relatively fast measurements of the intensities of major elements directly at the surface of sediment cores. Its results are usually presented in count rates or intensity of elements, which can be calibrated into element concentrations using further Energy Dispersive X-Ray Fluorescence (EDP-XRF) discrete geochemical analysis and an algorithm by (Weltje and Tjallingii, 2008).

$\mathrm{Fe}$ and $\mathrm{Ti}$ within marine sediment cores can be used as tracers of the siliciclastic components of terrestrial sediments, and vary proportionally to the terrigenous fraction in the sea floor, whereas $\mathrm{Ca}$ in this setting is largely derived from biogenic $\mathrm{CaCO}_{3}$ shell material (mostly pteropods, foraminifera, and calcareous nannoplankton; Govin et al., 2012). Some studies of marine sediments (i.e., Govin et al., 2012) have suggested that single element concentrations are sensitive to dilution effects (i.e., enhanced biological productivity, carbonate dissolution) to allow reliable reconstructions of terrestrial climate, which can also affect elemental ratios including $\mathrm{Ca}$ (e.g., Fe/Ca). Therefore, in an area where post 
depositional carbonate dissolution and/or overgrowth are negligible or ruled out, elemental ratios including $\mathrm{Ca}($ e.g., $\mathrm{Ti} / \mathrm{Ca}$ and $\mathrm{Fe} / \mathrm{Ca}$ ) can be used to discuss marine versus terrigenous input.

$\mathrm{Fe} / \mathrm{Ca}$ and $\mathrm{Ti} / \mathrm{Ca}$ ratios have hence been used to trace changes in terrigenous input of fluvial origin, particularly offshore northeastern Brazil, where repeated authors pointed out increases in the terrigenous input during Heinrich events due to southward shifts of the ITCZ (Arz et al., 1998; Arz et al., 1999; Jennerjahn et al., 2004; Jaeschke et al., 2007; Nace et al., 2014; Stríkis et al., 2015; Zhang et al., 2015).

The archive halves of GeoB3227-2 and GeoB3228-1 were scanned for Fe, Ti and $\mathrm{Ca}$ using an X-ray fluorescence (XRF) Core Scanner II (AVAATECH Serial No. 2, 10kV, and $0.35 \mathrm{~mA}$ ) at the MARUM - Center for Marine Environmental Sciences, University of Bremen, Germany. Prior and after daily analysis, the instrument was calibrated against a set of pressed powder standards (Jansen et al., 1998). The elements' intensity or counts were determined at $5 \mathrm{~mm}$ intervals with 20 seconds of irradiation time directly over the pristine surface of the archive halves of the cores. Acquired XRF spectra were processed with the WinAxil and WinBatch software packages. The resulting data were expressed as element intensities in counts per second.

\subsubsection{Calibration of XRF-scanner data via EDP-XRF / Calibração de dados de scanner} de XRF via EDP-XRF

$\mathrm{Fe}$, Ti and $\mathrm{Ca}$ absolute concentrations were measured using EDP-XRF on a Panalytical Epsilon $3 \mathrm{X}$ spectrometer. Analytical quality of the measurements were assessed by repeated analysis of several different certified standard reference materials (e.g. MAG-1; Govindaraju et al., 1994). The measured values were within $1 \%$ of accepted values. The standard deviation of replicated sediment samples was less than $2 \%$. The elements concentrations are expressed in grams per kilogram $(\mathrm{g} / \mathrm{kg})$ of dry sediment. $\mathrm{Ti} / \mathrm{Ca}$ and $\mathrm{Fe} / \mathrm{Ca}$ ratios discussion and conclusion are shown in the attached manuscript "South American summer monsoon decreased intensity related to the Bølling-Allerød interstadial” (Catunda et al., in prep). 


\section{Results / Resultados}

\subsection{Radiocarbon ages and age models / Idades radiocarbônicas e modelos de idade}

Age models of sediment cores GeoB3227-2 and GeoB3228-1 were established using 25 AMS ${ }^{14} \mathrm{C}$ ages, compiled on Table 5.1. Figure 5.1 shows the age models and the sedimentation rates of both cores.

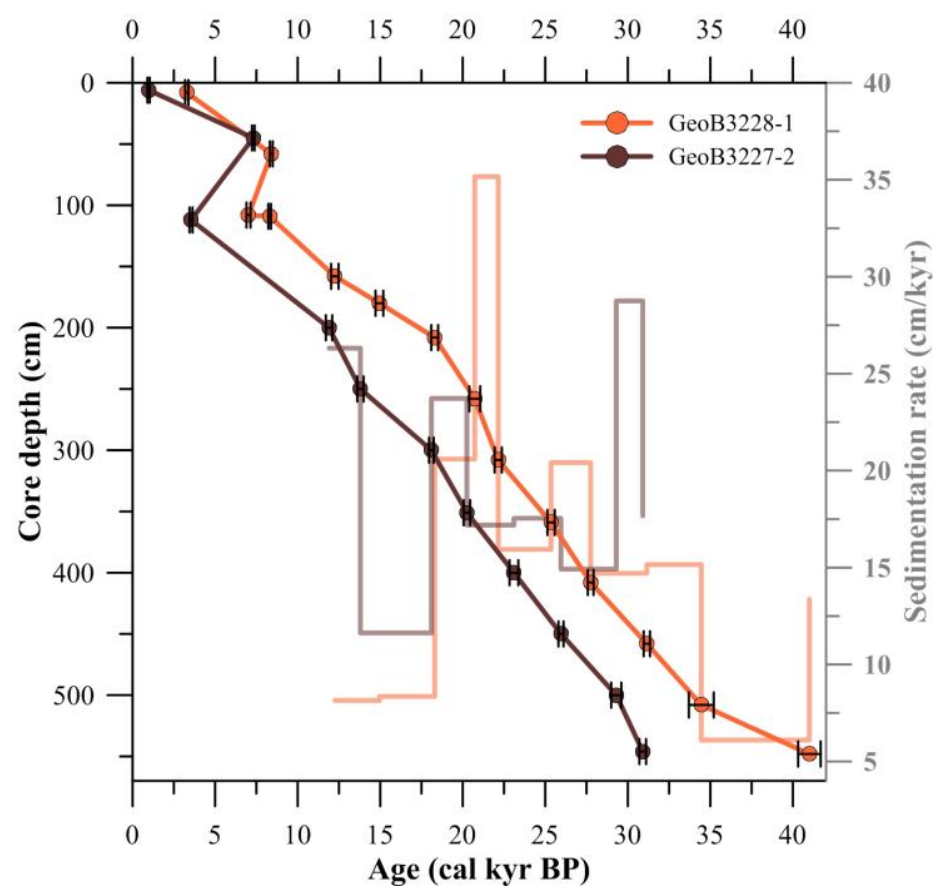

Figure 5.1 Age models and sedimentation rates for marine sediment cores GeoB3228-1 (orange) and GeoB3227-2 (dark brown). Sedimentation rates are represented in lighter colors. Error bars represent $2 \sigma$ uncertainty of the respective calibrated ages.

The gravity cores show quasi linear age models during deglacial and glacial periods, with high mean sedimentation rates (GeoB3227-2, $20 \mathrm{~cm} / \mathrm{kyr}$, and GeoB3228-1, $17 \mathrm{~cm} / \mathrm{kyr}$ ). Within the period when both cores overlap, the lowest sedimentation rates recorded in both cores occur from 18 to 13.8 cal kyr BP (ka hereafter, present established as 1950). Interestingly, both cores seem to have recorded a regional sedimentation disturbance during the early/middle Holocene. 
Table 5.1 Radiocarbon data available for marine sediment cores GeoB3227-2 and GeoB3228-1 (age reversals in dark red).

\begin{tabular}{|c|c|c|c|c|c|c|c|c|}
\hline Core ID & $\begin{array}{r}\text { Core } \\
\text { depth } \\
(\mathrm{cm})\end{array}$ & $\begin{array}{c}\text { Laboratory } \\
\text { ID }\end{array}$ & $\begin{array}{l}{ }^{14} \mathrm{C} \text { age } \\
\text { (years) }\end{array}$ & $\begin{array}{c}\text { Error } \\
\text { (years) }\end{array}$ & $\begin{array}{c}\text { Calibrated } \\
\text { age }\end{array}$ & $\begin{array}{c}\text { Calibrated } \\
\text { error }(2 \sigma, \\
\text { years })\end{array}$ & Species & Remarks \\
\hline \multirow{11}{*}{ GeoB3227-2 } & 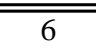 & "Beta-356363 & 1410 & 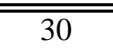 & $\overline{9970}$ & $\overline{772}$ & $=$ & \multirow{11}{*}{ Age reversal } \\
\hline & 45 & Beta-385292 & 6770 & 30 & 7310 & 79 & G. ruber & \\
\hline & 112 & Beta-385293 & 3640 & 30 & 3540 & 92 & G. ruber & \\
\hline & 200 & Beta-356364 & 10600 & 40 & 11900 & 193 & - & \\
\hline & 250 & Beta-385294 & 12330 & 40 & 13800 & 190 & G. ruber & \\
\hline & 300 & Beta-356365 & 15270 & 60 & 18100 & 142 & - & \\
\hline & 351 & Beta-385295 & 17180 & 50 & 20250 & 198 & $\begin{array}{c}\text { Planktic } \\
\text { foraminifera }\end{array}$ & \\
\hline & 400 & Beta-385296 & 19520 & 60 & 23100 & 266 & $\begin{array}{c}\text { Planktic } \\
\text { foraminifera }\end{array}$ & \\
\hline & 450 & Beta-385297 & 22070 & 80 & 25950 & 156 & $\begin{array}{c}\text { Planktic } \\
\text { foraminifera }\end{array}$ & \\
\hline & 500 & Beta-385298 & 25670 & 100 & 29300 & 308 & $\begin{array}{c}\text { Planktic } \\
\text { foraminifera }\end{array}$ & \\
\hline & 546 & Beta-385299 & 27120 & 120 & 30900 & 203 & $\begin{array}{l}\text { G. ruber / G. } \\
\text { sacculifer }\end{array}$ & \\
\hline \multirow{15}{*}{ GeoB3228-1 } & 8 & Poz-45335 & 3415 & 35 & 3280 & 99 & G. ruber & \multirow{7}{*}{ Age reversal } \\
\hline & 58 & Beta-361839 & 7930 & 40 & 8400 & 90 & $\begin{array}{l}\text { G. ruber / G. } \\
\text { sacculifer }\end{array}$ & \\
\hline & 108 & Beta-361840 & 6500 & 40 & 7020 & 122 & $\begin{array}{l}\text { G. ruber / G. } \\
\text { sacculifer }\end{array}$ & \\
\hline & 109 & Beta-385300 & 7850 & 30 & 8300 & 81 & $\begin{array}{c}\text { Planktic } \\
\text { foraminifera }\end{array}$ & \\
\hline & 158 & Beta-361841 & 10770 & 50 & 12250 & 226 & $\begin{array}{c}\text { G. ruber / G. } \\
\text { sacculifer }\end{array}$ & \\
\hline & 180 & Beta-409779 & 13020 & 50 & 14950 & 234 & G. ruber & \\
\hline & 208 & Beta-361842 & 15480 & 60 & 18300 & 206 & $\begin{array}{l}\text { G. ruber / G. } \\
\text { sacculifer }\end{array}$ & \\
\hline & & & & & & & & \multirow{8}{*}{$* *$} \\
\hline & 258 & Poz-45336 & 17580 & 120 & 20750 & 330 & $\begin{array}{c}\text { G. ruber / G. } \\
\text { sacculifer }\end{array}$ & \\
\hline & 308 & Beta-385301 & 18710 & 60 & 22150 & 220 & $\begin{array}{c}\text { Planktic } \\
\text { foraminifera }\end{array}$ & \\
\hline & 359 & Beta-385302 & 21380 & 70 & 25350 & 223 & $\begin{array}{c}\text { Planktic } \\
\text { foraminifera }\end{array}$ & \\
\hline & 408 & Beta-385303 & 24040 & 90 & 27750 & 172 & $\begin{array}{c}\text { Planktic } \\
\text { foraminifera }\end{array}$ & \\
\hline & 458 & Beta-385304 & 27570 & 120 & 31150 & 192 & $\begin{array}{c}\text { Planktic } \\
\text { foraminifera }\end{array}$ & \\
\hline & 508 & Poz-45337 & 30840 & 440 & 34450 & 754 & G. ruber & \\
\hline & 548 & Beta-385305 & 36800 & 330 & 41000 & 683 & $\begin{array}{c}\text { Planktic } \\
\text { foraminifera }\end{array}$ & \\
\hline
\end{tabular}

\footnotetext{
*Equal parts mixture between depths $350 \mathrm{~cm}$ and $352 \mathrm{~cm}$ because there was not enough planktic foraminifera in any individ $* *$ Partial mixture between depths $358 \mathrm{~cm}(1 / 3)$ and $360 \mathrm{~cm}(2 / 3)$ because there was not enough planktic foraminifera in any individual sample.
} 
The age models present a reversed age each at 45 and $58 \mathrm{~cm}$ of GeoB3227-2 and GeoB3228-1, respectively. We believe these age reversals are connected with a regional sedimentary disturbance visually identified by the reddish layers (discussed on subsections 5.3 and 6.1). We therefore calculated the age models excluding the ${ }^{14} \mathrm{C}$ ages within the reddish layers (at $45 \mathrm{~cm}$ and $112 \mathrm{~cm}$ of GeoB3227-2, and $58 \mathrm{~cm}, 108 \mathrm{~cm}$ and $109 \mathrm{~cm}$ of GeoB3228-1). Unfortunately, since the ages around $\sim 50 \mathrm{~cm}$ in both gravity cores were anomalous it was not possible to estimate sedimentation rates for the shallowest section of these cores. Thus, GeoB3227-2 covers the period between $11.9 \mathrm{ka}(200 \mathrm{~cm})$ to $31.2 \mathrm{ka}(556$ $\mathrm{cm}$ - estimated with linear extrapolation of the sedimentation rate), and GeoB3228-1 covers the period between $12.25 \mathrm{ka}(158 \mathrm{~cm})$ and $41 \mathrm{ka}(548 \mathrm{~cm})$.

\section{2. $\boldsymbol{\delta}^{\mathbf{1 8}} \mathbf{O}$ and $\boldsymbol{\delta}^{\mathbf{1 3}} \mathbf{C}$ of benthic foraminifera $/ \delta^{18} \mathrm{O}$ e $\delta^{13} \mathrm{C}$ de foraminiferos bentônicos}

To evaluate Cibicidoides spp. isotopic values and species specific isotopic offsets, Figure 5.2 shows $\delta^{18} \mathrm{O}$ and $\delta^{13} \mathrm{C}$ of all samples from the uppermost half of GeoB3228-1 divided by species.

In Figure 5.2, $\delta^{13} \mathrm{C}$ values of Cibicidoides spp. are distributed scatteredly through the $\mathrm{Y}$ axis. This scattering can be explained by the fact that Cibicidoides spp. is composed by a variable mixture of different Cibicidoides and Cibicides species with different species specific offsets, notably C. subhaidingerii (Holbourn et al., 2002) one of the most abundant (apparently) epibenthic species in the uppermost half of GeoB3228-1. In their work, Holbourn et al. (2002), found that a heavily calcified test morphotype described as $C$. subhaidingerii alpha shows lower values of $\delta^{13} \mathrm{C}(0.5-1 \%)$ when compared with $C$. subhaidingerii beta and Planulina wuellerstorfi / C. wuellerstorfi, plotting closer to values of $U$. peregrina. Within our record nevertheless, $\delta^{13} \mathrm{C}$ of $C$. subhaidingerii presents $\delta^{13} \mathrm{C}$ values around $2 \%$ lower than $C$. wuellerstorfi samples and between $0.7-1 \%$ lower than $U$. peregrina. $\delta^{18} \mathrm{O}$ of $C$. subhaidingerii was also found consistently higher than Planulina wuellerstorfi / $C$. wuellerstorfi $\left(\sim 0.65 \%\right.$ ) and closer to $U$. peregrina values. Explaining also why the $\delta^{13} \mathrm{C}$ values of $\sim 1000 \mathrm{~m}$ deep water for the Holocene and LGM published by Curry and Oppo (2005) are higher than our record, closer to C. wuellerstorfi isotopic values (Figure 5.2). Therefore, when integrating isotopic results from the whole marine sediment core, we decided to exclude the data of all Cibicidoides spp. samples that contained C. subhaidingerii of our 
record (43 out of the 61 samples from the selected time window from 12 to $41 \mathrm{ka}$ ). The epibenthic $\delta^{18} \mathrm{O}$ and $\delta^{13} \mathrm{C}$ values showed in Figures 5.3 and 5.4 include the results of the 17 remaining samples of Cibicidoides spp. along with the monospecific results of $C$. wuellerstorfi, C. pachyderma and Cibicides spp.. Intervals of more than $2 \mathrm{kyr}$ without Cibicidoides values were left as gaps.

Given that the age reversals coincided with the reddish layer, an unusual scattering on $\delta^{13} \mathrm{C}$ and $\delta^{18} \mathrm{O}$ data and also a $\mathrm{Fe} / \mathrm{Ca}$ anomaly (see section 5.3) we decided, for the moment, not to interpret the records until the bottom of the reddish layer (i.e., $150 \mathrm{~cm}$ core depth). Also, as our results were unevenly spaced in time and to preserve the timing of isotopic variability, we used the integrated interpolation function embedded on the Analyseries 2.0.8 software every $1 \mathrm{kyr}$ (Figures 5.3 and 5.4). Within the studied time window (12 to $41 \mathrm{ka}$ ), the reservoir $\delta^{18} \mathrm{O}$ changed considerably because of expansion and retraction of global ice volume. However, a recent paper (i.e., Lund et al., 2015) argues against the use of ice volume corrections in benthic foraminiferal data because of depth-dependent timing in the evolution of melt water $\delta^{18} \mathrm{O}$ signal, potentially yielding artificially large increases in temperature on ice volume corrected benthic foraminifera $\delta^{18} \mathrm{O}$. We therefore define the deglacial temperature increase using non-corrected data, and plot ice volume corrected data $\left(\delta^{18} \mathrm{O}_{\text {civc }}\right.$ and $\left.\delta^{18} \mathrm{O}_{\text {uivc }}\right)$ only for visual comparison in the discussion.

U. peregrina $\delta^{13} \mathrm{C}$ record begins with values around $-0.7 \%$ at $41.5 \mathrm{ka}$ and decrease to $0.95 \%$ at $39 \mathrm{ka}$, the approximate timing of Heinrich stadial 4 (Figure 5.3). It increases by $0.3 \%$ after the event, locally peaking at $37 \mathrm{ka}$. After that $\delta^{13} \mathrm{C}$ follows a decreasing trend reaching a minimum at $30 \mathrm{ka}(-1.2 \%)$. Until $22 \mathrm{ka}, \delta^{13} \mathrm{C}$ values oscillate around $-1.1 \%$ o without increasing or decreasing trends. $\delta^{13} \mathrm{C}$ values increase to $-0.9 \%$ around $20 \mathrm{ka}$, decreasing again to $-1.15 \%$ at $17 \mathrm{ka}$. From this point $\delta^{13} \mathrm{C}$ consistently increases until values reach the records maximum around $13 \mathrm{ka}(0 \%)$. The remaining $0.75 \mathrm{kyr}$ of our record is marked by a slight decrease of $-0.1 \%$. 


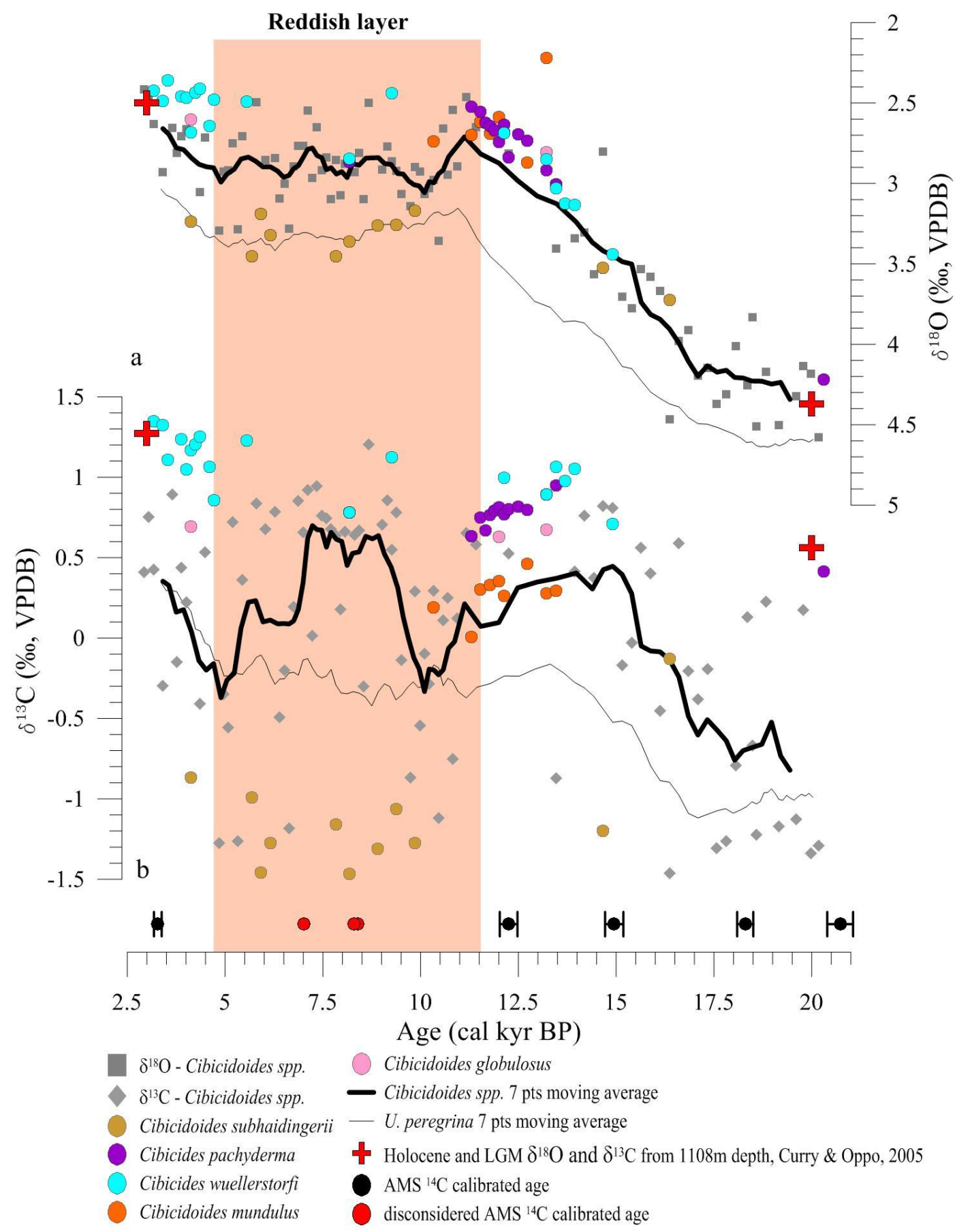

Higure 5.2: Benthic toraminiteral stable oxygen and carbon isotopic records tor the uppermost half of marine sediment core GeoB3228-1, divided by species. (a) $\delta^{18} \mathrm{O}$ values of all samples picked from the uppermost half of GeoB3228-1; (b) $\delta^{13} \mathrm{C}$ values of all samples picked from the uppermost half of GeoB3228-1. Gray diamonds and squares represent $\delta^{18} \mathrm{O}$ and $\delta^{13} \mathrm{C}$ of Cibicidoides spp., respectively. Thick black lines are the 7 points moving average curves of each set of Cibicidoides spp. isotopic data. Thin black lines are the 7 points moving average curves of Uvigerina peregrina isotopic data sets. Colored circles represent isotopic values of monospecific samples of Cibicidoides subhaidingerii, Cibicides pachyderma, Cibicides wuellerstorfi, Cibicides mundulus and Cibicidoides globulosus selected were these species were abundant. Black circles represent AMS ${ }^{14} \mathrm{C}$ calibrated ages and respective $2 \sigma$ uncertainties considered for the age model. Red circles represent anomalous ages within the reddish layer, excluded from the age model. Red crosses represent the geographically and depth closest, from the study site, $\delta^{18} \mathrm{O}$ and $\delta^{13} \mathrm{C}$ values for Holocene and Last Glacial Maximum (marine sediment core KNR159-105JPC, $27.35^{\circ} \mathrm{S} / 46.63^{\circ} \mathrm{W}$ / 1108 m, Curry and Oppo, 2005). 


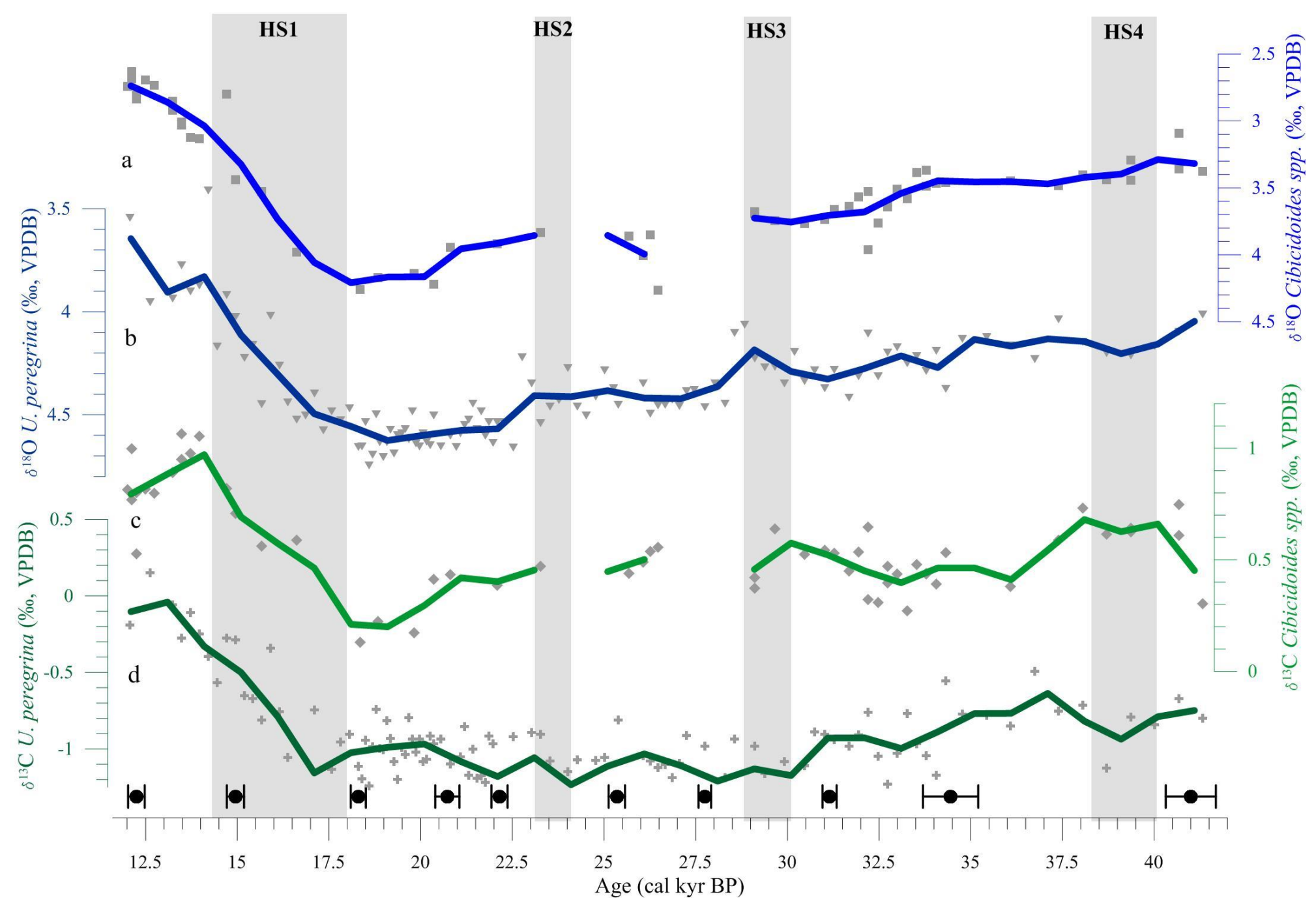

Figure 5.3: Benthic foraminiferal stable oxygen and carbon isotopic records for marine sediment core GeoB3228-1. (a) Cibicidoides spp. $\delta^{18} \mathrm{O}$ (gray squares) and $1 \mathrm{kyr}$ integrated interpolation (blue line); (b) U. peregrina $\delta^{18} \mathrm{O}$ (gray triangles) and $1 \mathrm{kyr}$ integrated interpolation (dark blue line); (c) Cibicidoides spp., C. wuellerstorfi and C. pachyderma $\delta^{13} \mathrm{C}$ (gray diamonds) and $1 \mathrm{kyr}$ integrated interpolation (light green line); (d) Uvigerina peregrina $\delta^{13} \mathrm{C}$ values (gray crosses) and $1 \mathrm{kyr}$ integrated interpolation (dark green line). Black circles represent AMS ${ }^{14} \mathrm{C}$ ages in cal kyr BP with respective $2 \sigma$ sigma uncertainty bars. 


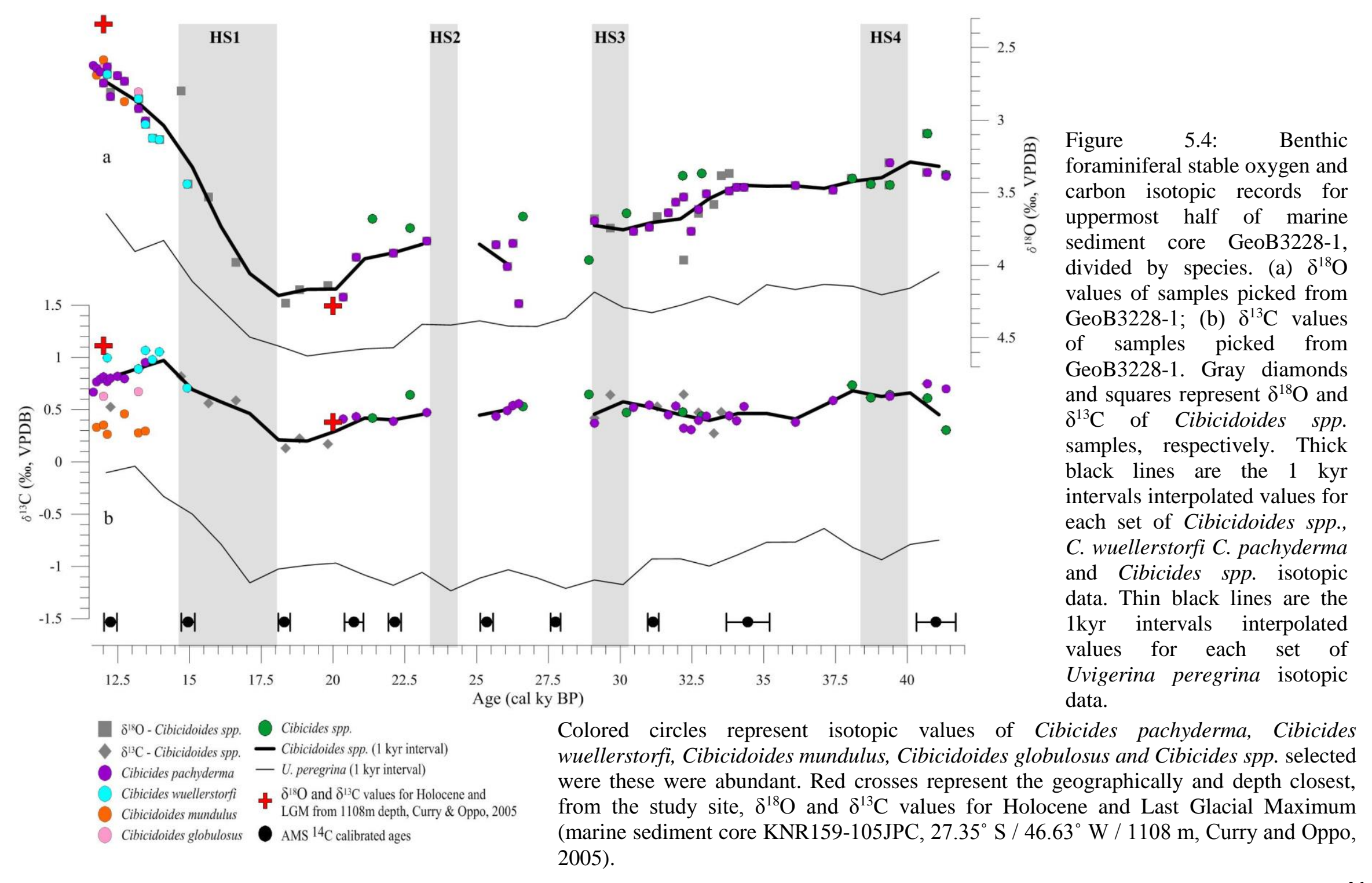


Cibicidoides spp. $\delta^{13} \mathrm{C}$ record presents, as expected, a ${ }^{13} \mathrm{C}$ enriched record in relationship to the $U$. peregrina (Figure 5.3). The difference or offset between $\delta^{13} \mathrm{C}_{\mathrm{c}}$ and $\delta^{13} \mathrm{C}_{\mathrm{u}}$ $\left(\Delta \delta^{13} \mathrm{C}\right)$ oscillated up to $0.9 \%$ ( $\left.\Delta_{\text {offset }}\right)$ within our record, from $0.7 \%$ around $12 \mathrm{ka}$ (minimum $\Delta \delta^{13} \mathrm{C}$ ) and $1.6 \%$ between 20 and $30 \mathrm{ka}$ (maximum $\Delta \delta^{13} \mathrm{C}$ ). The $\delta^{13} \mathrm{C}_{\mathrm{c}}$ record begins with values around $0.5 \%$ at $41 \mathrm{ka}$, which increase to $0.65 \%$ at between 40 and $38 \mathrm{ka}$, during the approximate duration of HS4. $\delta^{13} \mathrm{C}$ values decrease to $0.4 \%$ in the period between 36 and 33 ka and increase again to $0.6 \%$ until $30 \mathrm{ka}$ (around HS3). For the next $9 \mathrm{kyr}$ the values follow a decreasing trend reaching $0.4 \%$ at $21 \mathrm{ka}$. From this point until $18 \mathrm{ka}, \delta^{13} \mathrm{C}$ values decrease to the record's minimum of $0.2 \%$, remaining low between 19 and $18 \mathrm{ka}$, right before values begin a steady rise until $14 \mathrm{ka}$. At 14 ka values reach the record's maximum of 1\%o. From this peak onwards $\delta^{13} \mathrm{C}$ values decrease until $0.8 \%$, at $12.25 \mathrm{ka}$.

$U$. peregrina $\delta^{18} \mathrm{O}$ record can be divided in two domains. From the beginning of the record at 41.5 to $17 \mathrm{ka}$, the values have a general increasing trend varying between $4 \%$ and $4.65 \%$, the record's maximum. An exception to the decreasing trend is found at $29 \mathrm{ka}$, represented by an $0.2 \%$ increase, just after HS3. From $17 \mathrm{ka}$ until the end of the record, $\delta^{18} \mathrm{O}$ steadily decrease, interrupted only by a $0.1 \%$ oxcursion to higher values between 14 and 13 ka. The record's minimum, 3.65\%, is reached at the younger limit of our studied time period, at $12 \mathrm{ka}$.

Cibicidoides spp. $\delta^{18} \mathrm{O}$ record follows a similar trend of $U$. peregrina $\delta^{18} \mathrm{O}$, beginning at $3.3 \%$ at $41 \mathrm{ka}$, and adopting a general increasing trend until $18 \mathrm{ka}(4.2 \%), 1 \mathrm{kyr}$ after $U$. peregrina $\delta^{18} \mathrm{O}$ peaked. From $18 \mathrm{ka}$ until the end of the record, $\delta^{18} \mathrm{O}$ values steadily decrease until the record's minimum, $2.7 \%$, at $12 \mathrm{ka}$. Cibicidoides spp. $\delta^{18} \mathrm{O}$ values exhibit offset of $0.6 \%$ in relationship with $U$. peregrina (Holbourn et al., 2002). It is noteworthy that the Holocene and LGM $\delta^{18} \mathrm{O}$ (for $\sim 1000 \mathrm{~m}$ water depth) values published by Curry and Oppo (2005; Figure 5.4) fit very well our Cibicidoides spp. record (without $C$. subhaidingerii data). This shows that our $\delta^{18} \mathrm{O}$ record is replicable and coherent with other nearby published oxygen isotopic records.

\subsection{Major elements in bulk sediment / Elementos maiores em sedimento total}

We show $\ln (\mathrm{Fe} / \mathrm{Ca})$ and $\ln (\mathrm{Ti} / \mathrm{Ca})$, traditional element ratios usually employed to discuss variations of terrigenous input into oceanic basins (e.g., Arz et al., 1998; Jennerjahn et 
al., 2004; Govin et al., 2012), that should be closely related to effective moisture on the adjacent continent (Figure 5.5).

The EDP-XRF absolute concentrations were used to calibrate the scanner XRF intensities into calibrated proportions using the regression method described by Weltje and Tjallingii (2008) implemented in the software MATLAB.

$\mathrm{Fe} / \mathrm{Ca}$ and $\mathrm{Ti} / \mathrm{Ca}$ log-ratios are very similar within each core. GeoB3228-1 log-ratios are relatively stable from 42 to $37 \mathrm{ka}$, slightly increase until $20 \mathrm{ka}$ and decrease subtly from that age to $15.85 \mathrm{ka}$. At $15.85 \mathrm{ka}$ the log ratios decrease sharply, showing decrease in $\mathrm{Fe}$ and $\mathrm{Ti}$ in relationship with $\mathrm{Ca}$ and the records' minimum is reached at $13.6 \mathrm{ka}$. After $13.6 \mathrm{ka}$ the terrigenous fraction increases again until $12 \mathrm{ka}$, when log ratios reach previous than $15.85 \mathrm{ka}$ values. Within the period between 12 and $4.3 \mathrm{ka}$ we find the highest ratios. This portion of the core corresponds with the reddish layer and contains the age reversal observed on section 4.2.1 (Figure 5.5). From $4.3 \mathrm{ka}$ to the core top at $3.2 \mathrm{ka} \ln (\mathrm{Fe} / \mathrm{Ca})$ and $\ln (\mathrm{Ti} / \mathrm{Ca})$ assume relatively low values.

The EDP-XRF $\ln (\mathrm{Ti} / \mathrm{Ca})$ and $\ln (\mathrm{Fe} / \mathrm{Ca})$ used for scanner-XRF calibration show almost perfect fit to the calibrated values with little divergence on the oldest portion of the records, before $31 \mathrm{ka}$.

The shorter GeoB3227-2 $\ln (\mathrm{Ti} / \mathrm{Ca})$ and $\ln (\mathrm{Fe} / \mathrm{Ca})$ records show a similar trend to the one described for GeoB3228-1. The oldest half of the record, from 31 to $14.7 \mathrm{ka}$ is plateaushaped with relatively low amplitude oscillations. At $14.7 \mathrm{ka}$ onwards there's an abrupt decrease of log-ratios values until $13.7 \mathrm{ka}$, when they are at their lowest from that point to 13.1 ka. At $13.1 \mathrm{ka} \mathrm{Ti}$ and Fe proportions in relationship to Ca sharply increase and at $12.6 \mathrm{ka}$ they return to previous than $14.7 \mathrm{ka}$ values. From 12.6 to $11.6 \mathrm{ka}$ terrigenous proportions remain relatively stable. From 11.6 ka onwards it's possible to observe the same increase in terrigenous in relationship to (marine) $\mathrm{Ca}$ seen on GeoB3228-1. These values are also coincident with the reddish sediments layer and the age reversal showed in Figure 5.5 of the previous section. The youngest portion of the records (estimated age from 3.5 to $0.5 \mathrm{ka}$ ) also present relatively low log-ratios values as seen in GeoB3228-1.

The discussion about our $\mathrm{Fe} / \mathrm{Ca}$ and $\mathrm{Ti} / \mathrm{Ca}$ results can be found on section 5 of the paper "South American summer monsoon decreased intensity related to the Bølling-Allerød interstadial" (Catunda et al., in prep.), attached to this dissertation. 


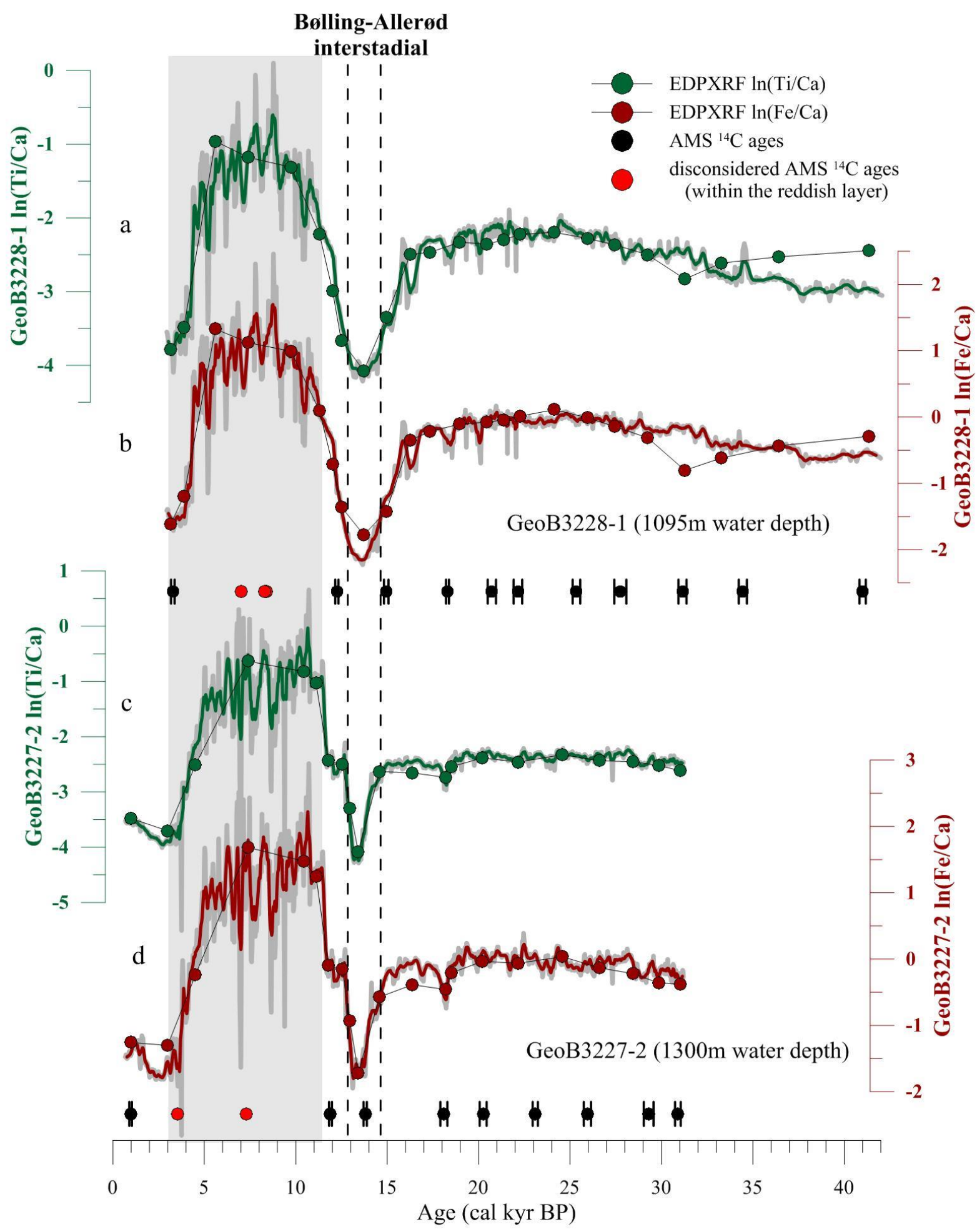

Figure 5.5: $\mathrm{Ti} / \mathrm{Ca}$ and $\mathrm{Fe} / \mathrm{Ca}$ records from cores $\mathrm{GeoB} 3228-1$ ( $\mathrm{a}$ and $\mathrm{b}$, respectively) and GeoB3227-2 (c and d, respectively). XRF scanner values are expressed as EDP-XRF calibrated $\ln (\mathrm{Ti} / \mathrm{Ca})$ and $\ln (\mathrm{Fe} / \mathrm{Ca})$ plotted together with raw EDP-XRF data. Black dots represent AMS ${ }^{14} \mathrm{C}$ ages with their respective $2 \sigma$ uncertainty bars. Red dots represent ages within the reddish layer that were not considered for age models on this graph. 
The periods with higher terrigenous concentrations, with approximate age of early and middle Holocene are coincident with the reddish brown layers described on both cores (see section 4.2.1) and the age reversals described in section 5.1. This disturbance seems to be regional (appears in both gravity cores, where it shows consistent ages and lithologic characteristics) and opens the possibility to study slope failure events and processes in the Espírito Santo Basin, a region of great interest for the oil industry. 


\section{Discussion / Discussão}

\subsection{Sedimentation on the core sites on the passage between the late}

\section{Pleistocene and Holocene / Sedimentação no local dos testemunhos}

\section{marinhos durante a passagem Pleistoceno tardio e Holoceno}

Today, sediment and water discharged from the Doce River are entrained in the Brazil Current and accumulate on the continental shelf closer to the river mouth (Bastos et al., 2015). During sea-level lowstand of the last glacial period, however, the Doce River mouth was located below the shelf break depth and the river channel incised the continental shelf and discharged directly into the upper continental slope. As the sea level rose during the last deglaciation, and overcame the shelf break ( $65 \mathrm{~m}$ water depth, Bastos et al., 2015) the low angle of the continental platform implied that the Doce River mouth shifted significantly away from the study site with every additional increment of sea level rise (Figure 6.1, Lambeck and Chappell, 2001, updated in 2007).

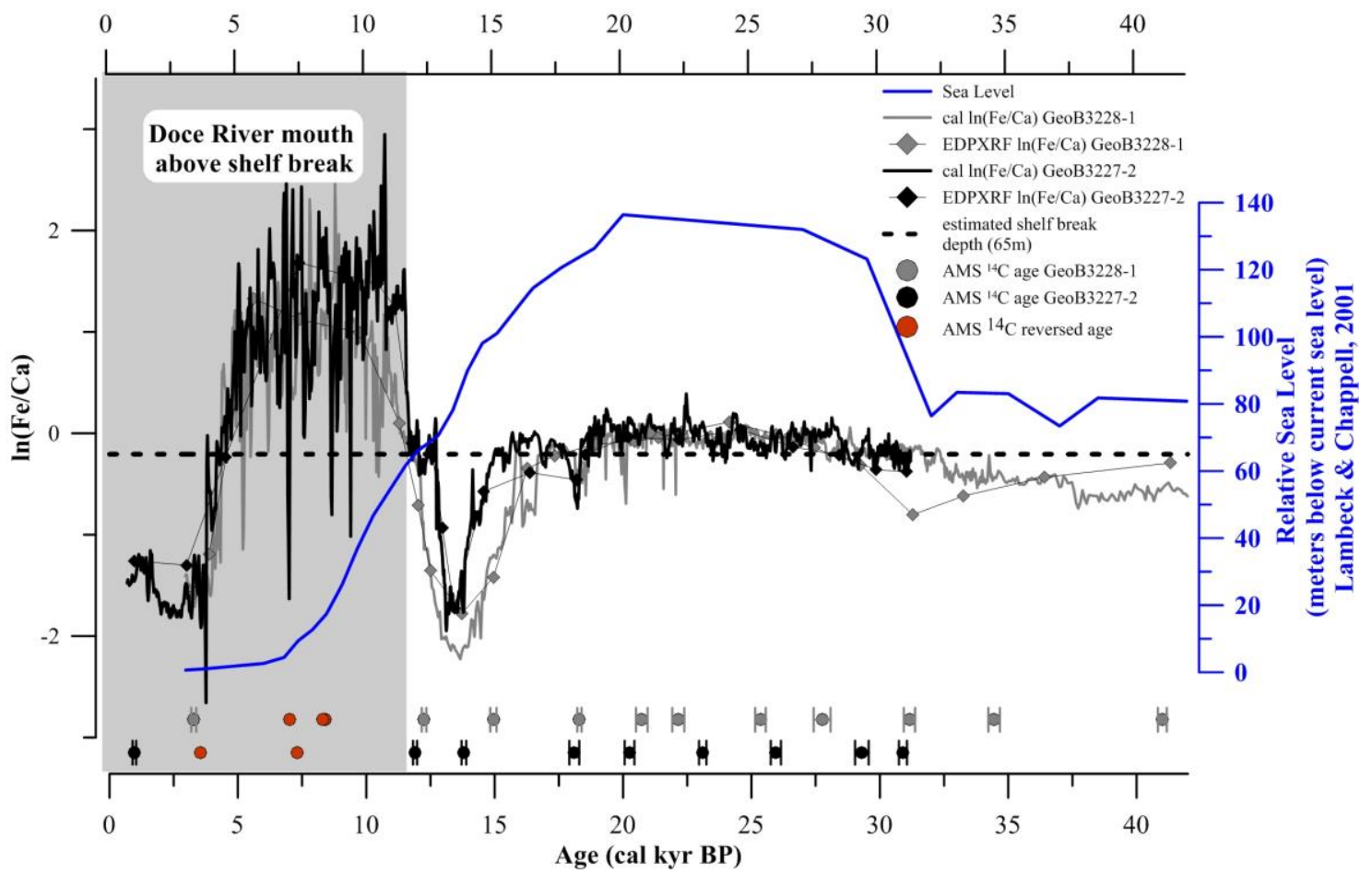

Figure 6.1: Relative sea level (Lambeck and Chappel, 2001; updated in 2007) and $\ln (\mathrm{Fe} / \mathrm{Ca})$ of GeoB3228-1 and GeoB3227-2 versus age. Grey dots represent AMS ${ }^{14} \mathrm{C}$ ages of marine sediment core GeoB3228-1 and their respective $2 \sigma$ uncertainty bars, black dots represent AMS ${ }^{14} \mathrm{C}$ ages of marine sediment core GeoB3227-2 and their respective $2 \sigma$ uncertainty bars, red dots represent reversed AMS ${ }^{14} \mathrm{C}$ ages. The grey rectangle marks the portion of the gravity cores that was deposited after the sea level overcame the local shelf break (plotted at $65 \mathrm{~m}$ water depth). 
We hypothesize that when sea level overcame the shelf break ( 12 ka) our study site became starved of terrigenous sediments, receiving rather occasional input from the adjacent continental shelf brought by slumps or turbidity currents. Sediments previously deposited in the Doce River plataform are simultaneously iron-rich, because of Doce River sediments, and relatively calcium-poor, because of the shallow depths in which it is located, possibly explaining the high $\mathrm{Fe} / \mathrm{Ca}$ and $\mathrm{Ti} / \mathrm{Ca}$ ratios in the reddish layers. Our hypothesis justifies the exclusion of the data obtained from the holocenic reddish layers containing age reversals on the studied cores.

\subsection{Changes in southern sourced water masses isotopic signature in the western South Atlantic during the late glacial and Termination I}

Currently GeoB3228-1 core site is bathed by UCDW. During the LGM however, our study depth in the western South Atlantic has been reported to be within the Glacial Antarctic Intermediate Water (GAAIW) depth interval, between 850 and $1200 \mathrm{~m}$ (Curry and Oppo, 2005; Makou et al., 2010; Tessin and Lund, 2013). AAIW and UCDW are both formed around Antarctica and have similar physical properties, being relatively fresh and nutrient rich (see Figures 2.2 and 4.4) in relationship to NADW, for example. To establish a relationship between GAAIW and the global climatic evolution, considering that AAIW is formed close to Antarctica, we compared our $\delta^{18} \mathrm{O}$ and $\delta^{13} \mathrm{C}$ results with temperature and $\mathrm{CO}_{2}$ data from Antarctic ice cores (Parrenin et al., 2013, Figure 6.2, and Bereiter et al., 2015, Figure 6.3).

As previously mentioned in subsection 4.2.4, benthic foraminiferal $\delta^{18} \mathrm{O}$ is a function of both temperature and the $\delta^{18} \mathrm{O}$ of the water in which the foraminifera grows (Epstein and Mayeda, 1953), which is in turn affected by changes in salinity and global ice volume (Waelbroeck et al., 2002). After corrections for global ice volume however, even though calcitic $\delta^{18} \mathrm{O}$ is affected by the interplay of temperature and salinity, the former dominates the equilibrium $\delta^{18} \mathrm{O}$ values in the deep ocean (Curry and Oppo, 2005). We therefore interpret $\delta^{18} \mathrm{O}$ of benthic foraminifera in terms of temperature and global ice volume oscillations (Figure 6.2). 


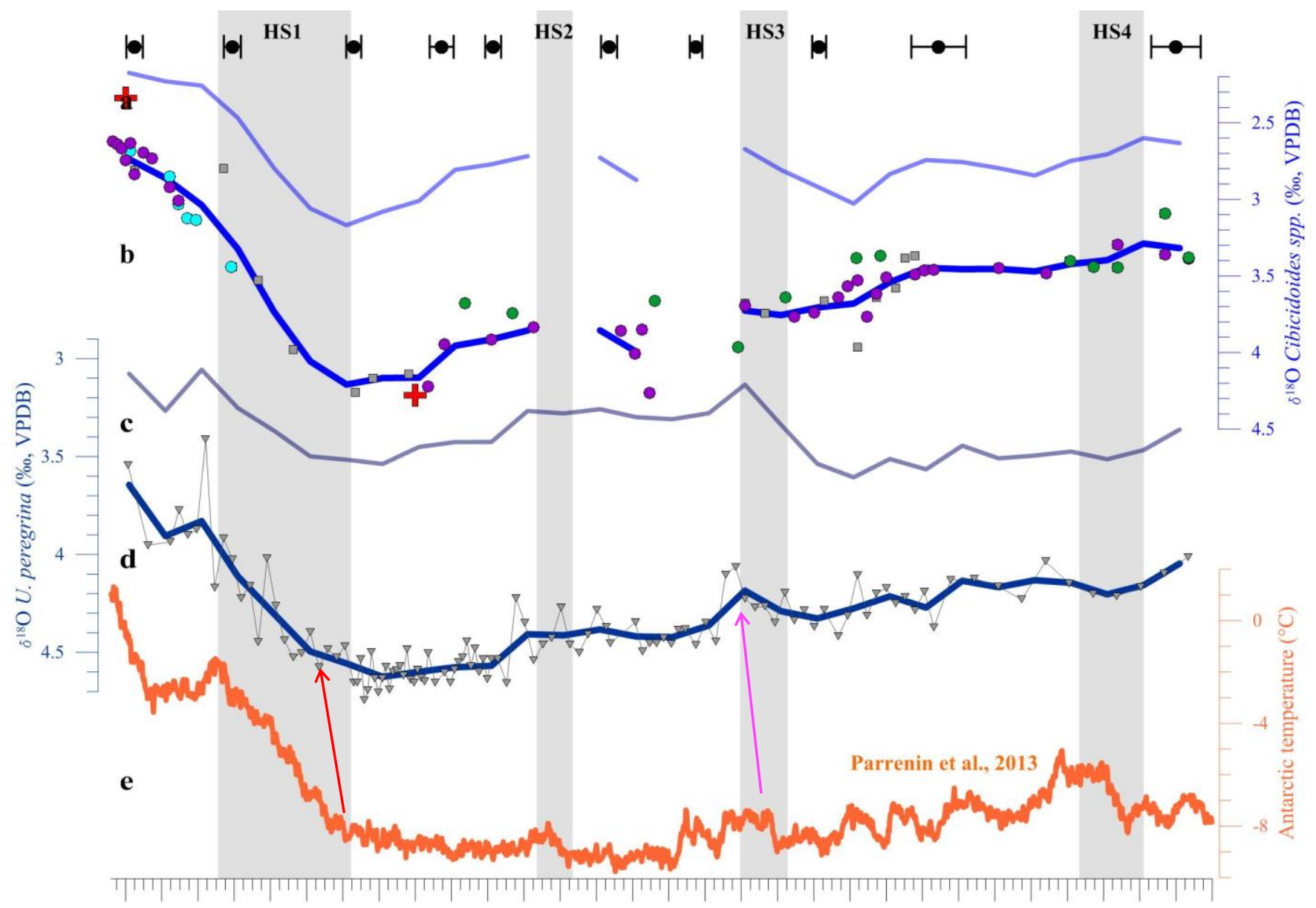

$\begin{array}{lllllllllllllllllllllllllllllll}12 & 13 & 14 & 15 & 16 & 17 & 18 & 19 & 20 & 21 & 22 & 23 & 24 & 25 & 26 & 27 & 28 & 29 & 30 & 31 & 32 & 33 & 34 & 35 & 36 & 37 & 38 & 39 & 40 & 41 & 42\end{array}$

Age (cal kyr BP)

Figure 6.2: (a) Ice volume corrected Cibicidoides $\delta^{18} \mathrm{O}$ composite interpolated every $1 \mathrm{kyr}$ (light blue line); (b) C. wuellerstorfi (cyan circles), C. pachyderma (purple circles), Cibicides spp. (green circles) and Cibicidoides spp. (gray squares, samples containing C. subhaidingerii were excluded) $\delta^{18} \mathrm{O}$ record and $1 \mathrm{kyr}$ integrated interpolation (blue line); (c) Ice volume corrected $U$. peregrina $\delta^{18} \mathrm{O}$ record interpolated every $1 \mathrm{kyr}$ (grayish blue line) (d) U. peregrina (upside down gray triangles) $\delta^{18} \mathrm{O}$ record and $1 \mathrm{kyr}$ integrated interpolation (navy blue line); (e) Antarctic temperature stack from five different ice cores (EDC, Vostok, Dome Fuji, TALDICE, and EDML, Parrenin et al., 2013). Black circles represent AMS ${ }^{14} \mathrm{C}$ ages in cal kyr BP with respective $2 \sigma$ sigma uncertainty bars. Red crosses represent $\delta^{18} \mathrm{O}$ of the geographically and depth closest, from the study site, for Holocene and Last Glacial Maximum (marine sediment core KNR159-105JPC, $27.35^{\circ} \mathrm{S} / 46.63^{\circ} \mathrm{W} / 1108 \mathrm{~m}$, Curry and Oppo, 2005). Heinrich Stadials from 1 to 4 are highlighted with gray rectangles (Sarnthein et al., 2001). 
Overall, likely due to higher resolution and species consistency our U. peregrina $\delta^{18} \mathrm{O}$ $\left(\delta^{18} \mathrm{O}_{\mathrm{u}}\right.$ and $\delta^{18} \mathrm{O}_{\mathrm{uivc}}$, when referred to ice volume corrected data) and $U$. peregrina $\delta^{13} \mathrm{C}\left(\delta^{13} \mathrm{C}_{\mathrm{u}}\right)$ records reflected Antarctic temperature and $\mathrm{CO}_{2}$ evolution better than their Cibicidoides counterparts $\left(\delta^{18} \mathrm{O}_{\mathrm{c}}\right.$ and $\delta^{18} \mathrm{O}_{\text {civc}}$, when referred to ice volume corrected data, and $\left.\delta^{13} \mathrm{C}_{\mathrm{c}}\right)$. As an example, on $\delta^{18} \mathrm{O}_{\mathrm{c}}$, the marked deglacial $\delta^{18} \mathrm{O}$ decrease began before than in the $\delta^{18} \mathrm{O}_{\mathrm{u}}$ record, at $18 \mathrm{ka}$. However, between 20 and $16 \mathrm{ka}$, the $\delta^{18} \mathrm{O}_{\mathrm{c}}$ record was defined only by 4 samples of mixed Cibicidoides species, and therefore we decided to base our conclusions regarding $\delta^{18} \mathrm{O}$ on the $\delta^{18} \mathrm{O}_{\mathrm{u}}$ record.

Although the Antarctic temperature composite (Figure 6.2; Parrenin et al., 2013) shows several relatively small temperature oscillations between $42 \mathrm{ka}$ and $27 \mathrm{ka}$, the only oscillation consistently found on our $\delta^{18} \mathrm{O}$ records within this time window is a $1.1^{\circ} \mathrm{C}$ increase in Antarctica during HS3 (at $29.9 \mathrm{ka}$, pink arrow on Figure 6.2). Contemporaneously, our high resolution $\delta^{18} \mathrm{O}_{\mathrm{u}}$ registered an $\sim 0.32 \%$ decrease (pink arrow on Figure 6.2). Considering that every $\sim 0.25 \%$ represents around a $1{ }^{\circ} \mathrm{C}$ change in cold waters (Marchitto et al., 2014), the $\delta^{18} \mathrm{O}_{\mathrm{u}} 0.32 \%$ decrease would be equivalent to a $1.25^{\circ} \mathrm{C}$ warming in GAAIW but centered at $29.0 \mathrm{ka}$, with a 900 years delay. The warming of GAAIW during HS3 could be linked to an slowdown of the AMOC described by Böhm et al. (2015) and a consequent long term accumulation of heat in the Southern Ocean or due to warming of GAAIW at its area of formation.

The most notable change in all $\delta^{18} \mathrm{O}$ records was the expressive $\delta^{18} \mathrm{O}$ decrease during the HS1 (red arrow on Figure 6.2). On our high resolution $\delta^{18} \mathrm{O}_{\mathrm{u}}$ record the deglacial decrease took place at $17 \mathrm{ka}$, in accordance with other related studies in western South Atlantic (Waelbroeck et al., 2011; Lund et al., 2015). Most of the global deglacial warming happened during the HS1, when temperatures in Antarctica rose around $2{ }^{\circ} \mathrm{C} / \mathrm{kyr}$ from 17.7 to $14.7 \mathrm{ka}$ (Parrenin et al., 2013). $\delta^{18} \mathrm{O}_{\mathrm{u}}$ also shows a $0.1 \%$ increase between 14.0 and $12.6 \mathrm{ka}$, which can be related with the $1.5^{\circ} \mathrm{C}$ temperature decrease in Antarctica during the Antarctic Cold Reversal (14.6 to 12.65 ka, Figure 6.2, Blunier et al., 1997; Stenni et al., 2001).

Foraminiferal calcite $\delta^{13} \mathrm{C}$ usually reflects a combination of several factors, markedly the ones related to nutrient cycling and isotopic fractioning at the oceanic surface due to airsea $\mathrm{CO}_{2}$ exchange $\left(\delta^{13} \mathrm{C}_{\mathrm{as}}\right.$, see subsection 4.2.4). Biological primary production in the euphotic zone concentrates ${ }^{12} \mathrm{C}$ in organic matter, enriching superficial water in ${ }^{13} \mathrm{C}$. Deeper in the water column, the ${ }^{12} \mathrm{C}$-rich organic matter is oxidized and remineralized, adding carbon 
with low $\delta^{13} \mathrm{C}$ to deep waters (Duplessy et al., 1984). Air-sea fractionation at cold temperatures cause ${ }^{13} \mathrm{C}$ enrichment in seawater, while warmer temperatures lead to ${ }^{13} \mathrm{C}$ isotopic depletion and reduced $\delta^{13} \mathrm{C}_{\mathrm{as}}$ values (Mook et al., 1974). Also, for comparisons between the LGM and modern $\delta^{13} \mathrm{C}$ values Duplessy et al. (1988) calculated an $0.3 \%$ o $\delta^{13} \mathrm{C}$ depletion during the glacial for the whole ocean. Peterson et al. (2014) updated this number to $0.38 \%$ and suggested that this global oceanic water $\delta^{13} \mathrm{C}$ decrease during the last glacial period was likely due to terrestrial carbon transfer to the deep ocean as originally proposed by Shackleton (1977)

Curry and Oppo (2005) at $27^{\circ} \mathrm{S}$ and during the LGM, characterized GAAIW as a highnutrient water mass with $\delta^{13} \mathrm{C}_{\mathrm{c}}$ values between 0.3 and $0.5 \%$. Makou et al. (2010) combined the $\delta^{13} \mathrm{C}_{\mathrm{c}}$ from Curry and Oppo (2005) with $\mathrm{Cd} / \mathrm{Ca}$ measurements and calculated the atmospheric contribution to GAAIW $\delta^{13} \mathrm{C}\left(\delta^{13} \mathrm{C}_{\mathrm{as}}\right)$ as $0.23 \%$ (between 899 and 1108 water depth) during the LGM, which would represent between $45 \%$ and $75 \%$ of the total GAAIW $\delta^{13} \mathrm{C}$ signal. Makou et al. (2010) also noted that there was a steeper gradient between GAAIW and SACW than with GNAIW, suggesting a greater degree of mixing with the deeper water mass. Correspondent core top data presented $\delta^{13} \mathrm{C}_{\mathrm{as}}$ of $1.22 \%$, which implied that GAAIW apparently had a significantly lower air-sea fractioning contribution in comparison to the modern AAIW (Makou et al., 2010). Other results from the Pacific and Indian sectors of GAAIW, however, exhibited much higher $\delta^{13} C_{a s}$ values than the ones observed in the Atlantic, suggesting enhanced ventilation of GAAIW in those regions during the LGM (Lynch-Stieglitz et al., 1994; Lynch-Stieglitz et al., 1996; Muratli et al., 2010). This apparent contradiction led Makou et al. (2010) to hypothesize that connectivity between the different sections of the Southern Ocean was restricted during the LGM and that their calculated GAAIW $\delta^{13} C_{\text {as }}$ values were specific to the South Atlantic. Later on Huang et al. (2014) used $\varepsilon_{\mathrm{Nd}}$ from unclean foraminifera, from a marine sediment core section at $10^{\circ} \mathrm{N}$, to infer decreased latitudinal extent of GAAIW and increased mixture between GAAIW and GNAIW during the northern hemispheric cold periods HS1 and YD. The combination between their $\varepsilon_{\mathrm{Nd}}$ and ${ }^{231} \mathrm{~Pa} /{ }^{230} \mathrm{Th}$ (McManus et al., 2004) showed that the decreased GAAIW latitudinal extent was associated with decreased AMOC strength, which therefore gave support for decreased GAAIW ventilation during the LGM and potential ventilation seesawing between Pacific and Atlantic sectors of GAAIW (Makou et al., 2010). 


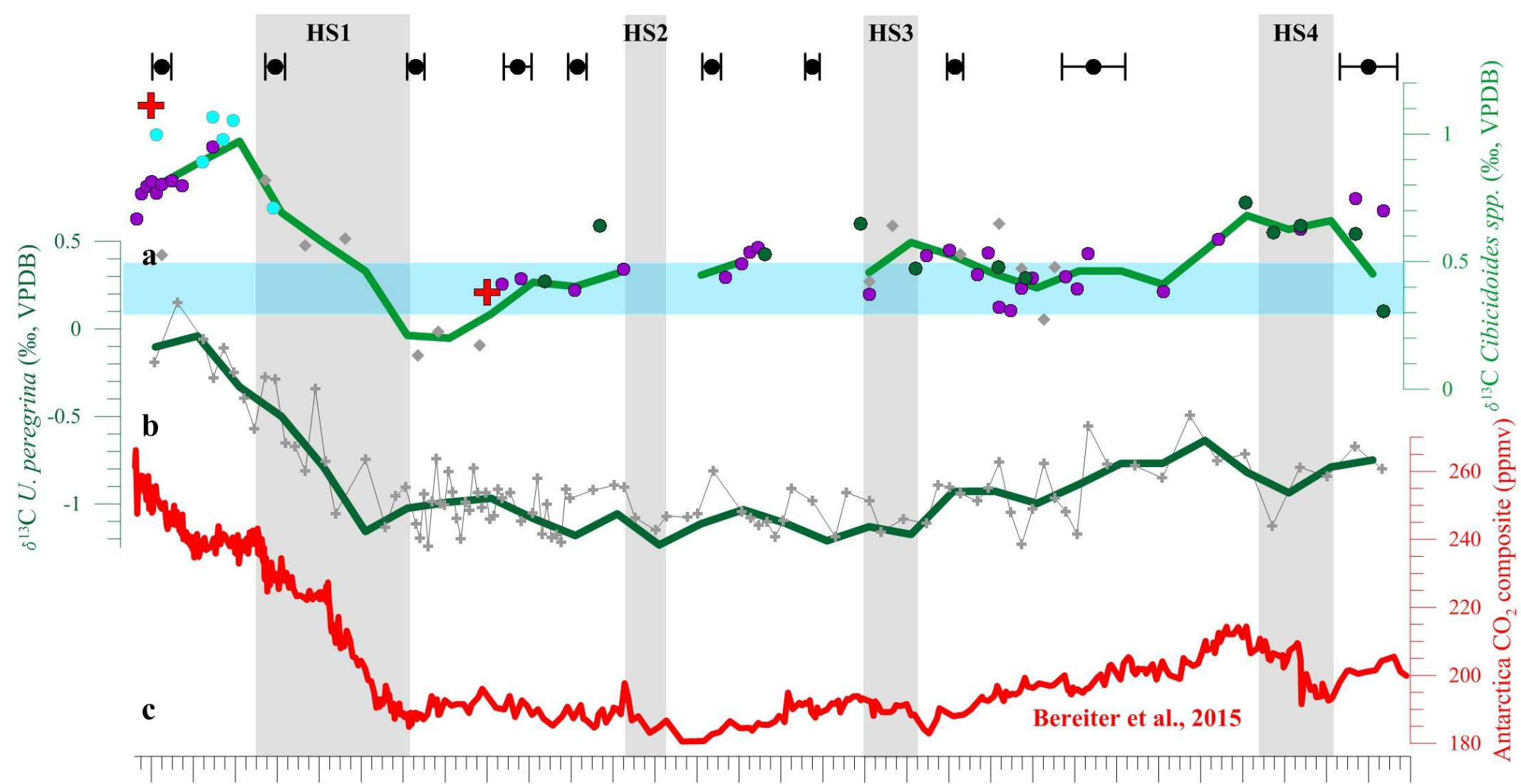

$\begin{array}{lllllllllllllllllllllllllllllll}12 & 13 & 14 & 15 & 16 & 17 & 18 & 19 & 20 & 21 & 22 & 23 & 24 & 25 & 26 & 27 & 28 & 29 & 30 & 31 & 32 & 33 & 34 & 35 & 36 & 37 & 38 & 39 & 40 & 41 & 42\end{array}$ Age (cal kyr BP)

Figure 6.3: (a) C. wuellerstorfi (cyan circles), C. pachyderma (purple circles), Cibicides spp. (green circles) and Cibicidoides spp. (gray diamonds, samples containing $C$. subhaidingerii were excluded) $\delta^{13} \mathrm{C}$ record and $1 \mathrm{kyr}$ integrated interpolation (light green line); (b) $U$. peregrina (gray crosses) $\delta^{13} \mathrm{C}$ record and $1 \mathrm{kyr}$ integrated interpolation (dark green line); (c) Antarctic composite ice core atmospheric $\mathrm{CO}_{2}$ data (WAIS, Siple Dome and TALDICE, Bereiter et al., 2015 and references therein). Black circles represent AMS ${ }^{14} \mathrm{C}$ ages in cal kyr BP with respective $2 \sigma$ sigma uncertainty bars. Red crosses represent the geographically and depth closest, $\delta^{13} \mathrm{C}$ values for Holocene and Last Glacial Maximum of marine sediment core KNR159-105JPC (27.35 $\mathrm{S} / 46.63^{\circ} \mathrm{W} / 1108 \mathrm{~m}$ water depth, Curry and Oppo, 2005). Heinrich Stadials from 1 to 4 are highlighted with gray rectangles (Sarnthein et al., 2000). Expected range of $\delta^{13} \mathrm{C}$ values $(0.3-0.5 \%$ for GAAIW during the LGM, Curry and Oppo, 2005) are marked with a light blue rectangle. 
Our $\delta^{13} \mathrm{C}_{\mathrm{c}}$ composite data are consistent with GAAIW $\delta^{13} \mathrm{C}$ expected values for the LGM (between 0.3 and $0.5 \%$, Curry and Oppo, 2005; Figure 6.3). Notable exceptions, when $\delta^{13} \mathrm{C}_{\mathrm{c}}$ was not between the 0.3 to $0.5 \%$ range, were during HS4, HS3 and before HS1. Between 37.6 and $41 \mathrm{ka}$, within the HS4 defined time range (Sarnthein et al., 2000), $\delta^{13} \mathrm{C}_{\mathrm{c}}$ values were relatively higher $(\sim 0.65 \%$ ), which could be explained by several hypothesis: diminished productivity above in the water column, mixture with the higher $\delta^{13} \mathrm{C}$ bearer GNAIW, or a general increased air-sea fractionation and ${ }^{13} \mathrm{C}$-enrichment in GAAIW at its formation zone, because of decreased temperatures and/or decreased wind mixing. For this work we have not analyzed planktic foraminifera, which would allow us to check for the possible productivity decrease during HS4 in the photic zone, so this possibility can only be resolved with future analysis. The Antarctic temperature composite temperature (Figure 6.2c, (Parrenin et al., 2013) shows that during the HS4, temperatures actually increased in Antarctica, deeming unlikely that the $\sim 0.15 \% \delta^{13} \mathrm{C}_{\mathrm{c}}$ increase (in relationship to $0.5 \%$ in $\delta^{13} \mathrm{C}_{\mathrm{c}}$ during the LGM and at $27^{\circ} \mathrm{S}$, (Curry and Oppo, 2005) was associated to increased air-sea fractioning at GAAIW's formation zone.

Centered at $30.2 \mathrm{ka}$, within the HS3 time window (Sarnthein et al., 2000), $\delta^{13} \mathrm{C}_{\mathrm{c}}$ was again higher than the LGM expected range ( $0.57 \%$ ). Assuming that HS4 and HS3 $\delta^{13} \mathrm{C}_{\mathrm{c}}$ increases were both due to the same process, recognizing the lack of productivity data from planktic foraminifera, as well as an unlikely $\delta^{13} \mathrm{C}_{\mathrm{as}}$ enrichment during both HS, lead us to suggest that our $\delta^{13} \mathrm{C}_{\mathrm{c}}$ increases were due to higher mixture between southern and northern component waters. This higher mixture rate implies decreased GAAIW formation at SH high latitudes and is supported by reported decreased AMOC strength during $\mathrm{NH}$ cold events (Makou et al., 2010; Böhm et al., 2015; see Figure 2.4).

Lower than expected $\delta^{13} \mathrm{C}_{\mathrm{c}}$ values between 20 and $18 \mathrm{ka}$ could indicate increased productivity in the photic zone and ${ }^{12} \mathrm{C}$-rich detritus rainfall to the bottom of the water column, which should be tested by future analysis in planktic foraminifera. Additionally, given that the three samples available for this interval are a mixture of Cibicidoides species (Cibicidoides spp.) any interpretation using our $\delta^{13} \mathrm{C}_{\mathrm{c}}$ record during this period (20 to $18 \mathrm{ka}$ ) should consider possibly unaccounted species-specific offsets effects. In addition, the closest $\delta^{13} \mathrm{C}_{\mathrm{c}}$ available data, from marine sediment core KNR159-105JPC $\left(27.35^{\circ} \mathrm{S} / 46.63^{\circ} \mathrm{W} / 1108\right.$ m water depth; Curry and Oppo, 2005), does not support a regional productivity increase (Figure 6.3 and other $\delta^{13} C_{c}$ data from the Brazil Margin transect; Curry and Oppo, 2005; 
Makou et al., 2010; Tessin and Lund, 2013). The $\delta^{13} \mathrm{C}_{\mathrm{c}} \sim 0.6 \%$ increase during HS1 began between 18 and $17 \mathrm{ka}$, in accordance with other published data in the Brazil Margin (Tessin and Lund, 2013). This long standing $\delta^{13} \mathrm{C}_{\mathrm{c}}$ increase is probably related to the combination of several factors, among them increased mixture with higher $\delta^{13} \mathrm{C}$ waters (related with AMOC quasi-halt during HS1; McManus et al., 2004; Böhm et al., 2015), increased atmospheric pCO2 at the formation zone of GAAIW (Marcott et al., 2014; Bereiter et al., 2015) and isotopic adjustment for the global oceanic water $\delta^{13} \mathrm{C}$ increase since the last glacial (Peterson et al., 2014).

There have been several suggestions that AAIW/GAAIW could have been a carrier for ${ }^{14} \mathrm{C}$ and ${ }^{13} \mathrm{C}$-depleted abyssal waters that contributed for global $40 \mathrm{ppm} \mathrm{CO}_{2}$ rise during the "Mystery Interval" ( 17.5 to 14.5 ka; Broecker and Barker, 2007; Marchitto et al., 2007). Sortor (2012) investigated the $\Delta^{14} \mathrm{C}$ of GAAIW during the deglaciation and found however that it followed the atmospheric trend, excluding Atlantic section of GAAIW as a possible carrier for the ${ }^{14} \mathrm{C}$-depleted carbon that contributed for the large atmospheric warming during HS1 (Broecker and Barker, 2007; Parrenin et al., 2013).

$U$. peregrina $\delta^{13} \mathrm{C}\left(\delta^{13} \mathrm{C}_{\mathrm{u}}\right)$ are usually of difficult interpretation because the assessment of its metabolic effects (i.e., species specific offset) in the $\delta^{13} \mathrm{C}$ signal is hampered by the dominance of locally specific environmental factors, including gradients between $\delta^{13} \mathrm{C}_{\text {DIC }}$ and $\mathrm{CO}_{3}{ }^{2-}$ in pore water and near-surface sediment, controlled by remineralization of organic matter (McCorkle et al., 1990; Schmiedl et al., 2004). Zahn et al. (1986) showed that $\delta^{13} \mathrm{C}$ values for $U$. peregrina and C. wuellerstorfi did not run parallel over the past glacialinterglacial cycles, which was also described in several other studies (e.g., Elmore et al., 2015). Species of the Cibicidoides genera usually live on top of the sediment (epibenthic), thereby accurately recording the conditions of the bottom water. Species of the Uvigerina genera, however, live in the sediment (endobenthic) and its $\delta^{13} \mathrm{C}$ signal usually reflects the conditions of the pore water, strongly influenced by the sedimentation of organic substance, rather than the true bottom water (Zahn et al., 1986). Therefore, U. peregrina $\delta^{13} \mathrm{C}$ cannot be adjusted to $C$. wuellerstorfi, the most reliable benthic recorder of bottom water $\delta^{13} C_{\text {DIC }}$ (Duplessy et al., 1984; Schmiedl and Mackensen, 2006) by any constant which is generally valid through glacial and interglacial times. Elmore et al. (2015) calculated the offset between $U$. peregrina and Cibicidoides $\delta^{13} \mathrm{C}\left(\Delta \delta^{13} \mathrm{C}\right)$ within the Pacific sector of GAAIW and concluded that it amounted to $\sim 0.6 \%$ o during interglacials and $\sim 1.4 \%$ o during glacials $\left(\Delta_{\text {offset }}=\right.$ 
$0.8 \%$ between glacials and interglacials), values which are consistent with our own data (see section 5.2) .

Nevertheless, our high-resolution $\delta^{13} \mathrm{C}_{\mathrm{u}}$ record present good visual agreement with long term trends observed in the $\delta^{13} \mathrm{C}_{\mathrm{c}}$ composite (Figure 6.3). On millennial time scales however, $\delta^{13} \mathrm{C}_{\mathrm{u}}$ is decoupled from $\delta^{13} \mathrm{C}_{\mathrm{c}}$ and do not show clear evidence of specific oscillations that could be related with possible HS3 and HS4 AMOC decreased strength (Böhm et al., 2015). Hesse et al. (2014) summarized the magnitude of all known factors which influence $\delta^{13} \mathrm{C}_{\mathrm{u}}$ and concluded that alkalinity, $\mathrm{pH}$ and productivity in the water column had less impact on $\delta^{13} \mathrm{C}_{\mathrm{u}}$ than the water $\delta^{13} \mathrm{C}_{\mathrm{DIC}}$ itself.

Our high resolution $\delta^{13} \mathrm{C}_{\mathrm{u}}$ record presents a striking resemblance with variations on the Antarctic atmospheric $\mathrm{CO}_{2}$ record (Bereiter et al., 2015), showing a 900 years delay $\left(\mathrm{r}^{2}=0.85\right.$ between Antarctic atmospheric $\mathrm{CO}_{2}$ and our $\delta^{13} \mathrm{C}_{\mathrm{u}}$, and $\mathrm{r}^{2}=0.95$ when comparing Antarctic atmospheric $\mathrm{CO}_{2}$ with $\delta^{13} \mathrm{C}_{\mathrm{u}}$ on its age model minus 900 years; Figure 6.4). Its most notable feature is the $1.15 \% \delta^{13} \mathrm{C}_{\mathrm{u}}$ increase from 17 to $13 \mathrm{ka}$. Since $U$. peregrina is usually considered to reflect pore water geochemistry and our $\delta^{13} \mathrm{C}_{\mathrm{c}}$ supports the interpretation that GAAIW strength oscillated with AMOC slowdowns (which do not seem to impact our $\delta^{13} \mathrm{C}_{\mathrm{u}}$ ), this resemblance creates a conundrum. We suggest that our $\delta^{13} \mathrm{C}_{\mathrm{u}}$ is primarily recording the global oceanic $0.38 \% \delta^{13} \mathrm{C}_{\text {DIC }}$ decrease during glacial times (Duplessy et al., 1988; Peterson et al., 2014), in itself correlated with atmospheric $\mathrm{CO}_{2}$. Furthermore, we suggest that the remaining $\sim 0.77 \%$ (1.15 - $0.38 \%$ ) $\delta^{13} \mathrm{C}_{\mathrm{u}}$ increase registered between 17 and $13 \mathrm{ka}$ is related to pore water geochemistry oscillations induced by the glacial to deglacial oceanic chemical change $\left(\Delta_{\text {offset }}=0.9 \%\right.$ between 20 and $12 \mathrm{ka}$, see section 5.2).

Primarily the atmospheric $\mathrm{CO}_{2}$ rise, the pore geochemistry variables of which $\Delta_{\text {offset }}$ is consisted and the $0.38 \%$ global ocean carbon isotopic difference between glacial and interglacial are likely related by a causal link, which not necessarily would be the Antarctic $\mathrm{CO}_{2}$ rise itself (a ${ }^{13} \mathrm{C}$-depleated carbon release from an abyssal oceanic source would also affect all of them, for example). However, the timing with which our $\delta^{13} \mathrm{C}_{\mathrm{u}}$ rose implies that at least the Atlantic sector geochemical change between glacial and deglacial was almost $1 \mathrm{kyr}$ later than the Antarctic $\mathrm{CO}_{2}$ rise. Our data therefore, in agreement with the findings of Sortor (2012), does not support ${ }^{13} \mathrm{C}$-depleated degassing from an Atlantic abyssal source. 
Also, our results suggest that GAAIW $\delta^{13} \mathrm{C}$ changes potentially related with AMOC slowdowns did not impact pore water geochemistry at our study site. However we allow that our interpretations require further study to be confirmed. Next steps could be investigating other proxies, such as $\delta^{13} \mathrm{C}$ of planktic foraminifera and $\mathrm{Cd} / \mathrm{Ca}$, to distinguish between paleoproductivity and $\delta^{13} \mathrm{C}_{\mathrm{as}}$ variations in our $\delta^{13} \mathrm{C}_{\mathrm{c}}$ and $\delta^{13} \mathrm{C}_{\mathrm{u}}$ records.

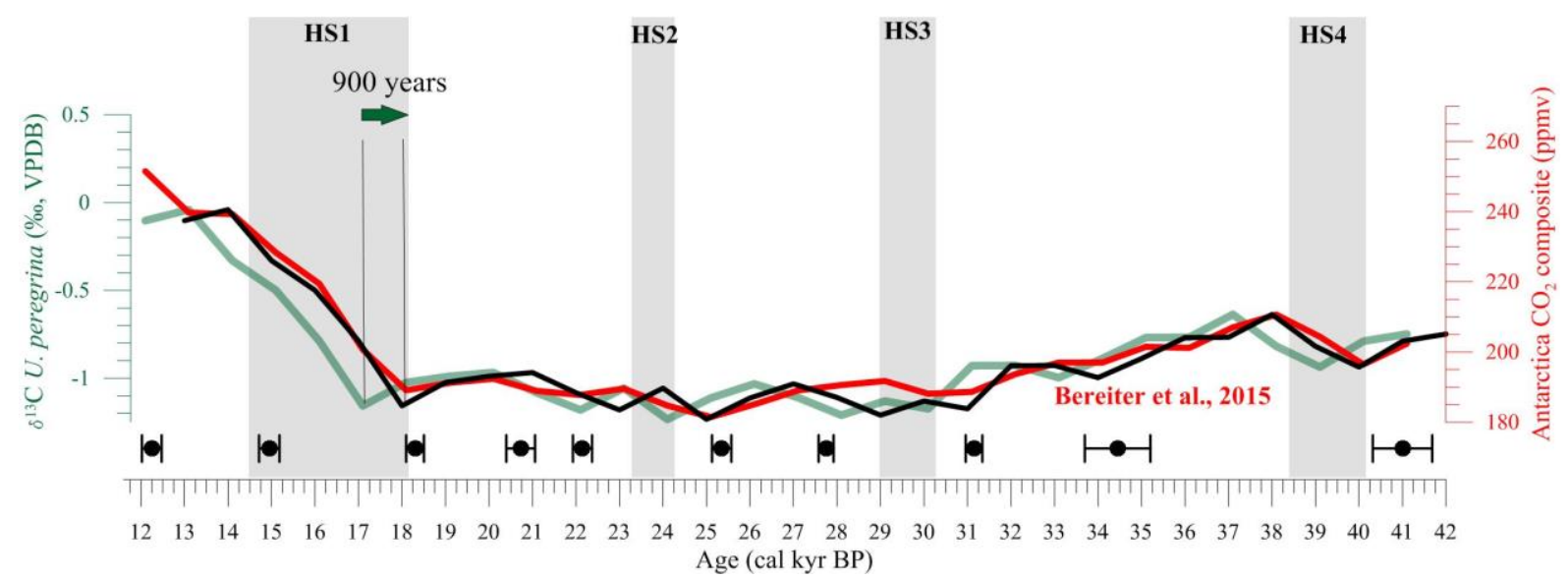

Figure 6.4: Comparison between $1 \mathrm{kyr}$ integrated interpolations of GeoB3228-1 U. peregrina $\delta^{13} \mathrm{C}$ record (light green line) and Antarctic composite ice core atmospheric $\mathrm{CO}_{2}$ data (red line, WAIS, Siple Dome and TALDICE, Bereiter et al., 2015 and references therein). GeoB3228-1 U. peregrina $\delta^{13} \mathrm{C}$ record was replotted adding 900 years to its original age model for comparison (black line). Black circles represent AMS ${ }^{14} \mathrm{C}$ ages in cal kyr BP with respective $2 \sigma$ sigma uncertainty bars.

\subsection{South American summer monsoon decreased intensity related to the} Bølling-Allerød interstadial / Diminuição da intensidade do Sistema de monções de verão Sul Americano relacionado ao interestadial BøllingAllerød

Please refer to the attached manuscript "South American summer monsoon decreased intensity related to the Bølling-Allerød interstadial" (Catunda et al., in prep.) for the discussion and conclusions on major elements in bulk sediments of the marine sediment core GeoB3228-1. 


\section{Conclusions / Conclusões}

- AMOC slowdown potentially led to warming of GAAIW during HS3, which can be explained by long term accumulation of heat in the Southern Ocean during decreased AMOC strength scenario, which is supported by Cibicidoides $\delta^{13} \mathrm{C}$ record, or due to warming of GAAIW at its area of formation.

- During HS4, AMOC slowdown may have led to increased mixture between GAAIW and GNAIW.

- We have no sign of an abyssal ${ }^{13} \mathrm{C}$-depleted carbon release in intermediate waters of western South Atlantic during the deglaciation. 


\section{References / Referências Bibliográficas}

Adkins, J.F., McIntyre, K., and Schrag, D.P., 2002, The salinity, temperature, and delta 180 of the glacial deep ocean: Science, v. 298, no. 5599, p. 1769-1773, doi: 10.1126/science.1076252.

Alley, R.B., and Clark, P.U., 1999, The deglaciation of the Northern Hemisphere: A Global Perspective: Annual Review of Earth and Planetary Sciences, v. 27, no. 1, p. 149-182, doi: 10.1146/annurev.earth.27.1.149.

Alves, R.A., 1999, Estudo sismoestratigráfico da Bacia do Brasil: Universidade Federal Fluminense, $127 \mathrm{p}$.

Anderson, D.E., 1997, Younger Dryas research and its implications for understanding abrupt climatic change: Progress in Physical Geography, v. 21, no. 2, p. 230-249, doi: $10.1177 / 030913339702100203$.

Arz, H.W., Pätzold, J., and Wefer, G., 1999, Climatic changes during the last deglaciation recorded in sediment cores from the northeastern Brazilian Continental Margin: GeoMarine Letters, v. 19, no. 3, p. 209-218, doi: 10.1007/s003670050111.

Arz, H.W., Pätzold, J., and Wefer, G., 1998, Correlated millennial-scale changes in surface hydrography and terrigenous sediment yield inferred from last-glacial marine deposits off northeastern Brazil: Quaternary Research, v. 50, no. 2, p. 157-166, doi: 10.1006/qres.1998.1992.

Barker, S., Diz, P., Vautravers, M.J., Pike, J., Knorr, G., Hall, I.R., and Broecker, W.S., 2009, Interhemispheric Atlantic seesaw response during the last deglaciation: Nature, v. 457, no. 7233 , p. 1097-1102, doi: 10.1038/nature07770.

Barros, V., Gonzalez, M., Liebmann, B., and Camilloni, I., 2000, Influence of the South Atlantic convergence zone and South Atlantic sea surface temperature on interannual summer rainfall variability in Southeastern South America: Theoretical and Applied Climatology, v. 67, p. 123-133, doi: 10.1007/s007040070002.

Bastos, A.C., Quaresma, V.S., Marangoni, M.B., D'Agostini, D.P., Bourguignon, S.N., Cetto, P.H., Silva, A.E., Filho, G.M.A., Moura, R.L., and Collins, M., 2015, Shelf morphology as an indicator of sedimentary regimes: A synthesis from a mixed siliciclastic-carbonate shelf on the eastern Brazilian margin: Journal of South American Earth Sciences, v. 63, p. 125-136, doi: 10.1016/j.jsames.2015.07.003.

Bereiter, B., Eggleston, S., Schmitt, J., Nehrbass-Ahles, C., Stocker, T.F., Fischer, H., Kipfstuhl, S., and Chappellaz, J., 2015, Revision of the EPICA Dome C CO2 record from 800 to 600 kyr before present: Geophysical Research Letters,, p. 1-8, doi: 10.1002/(ISSN)1944-8007.

Blunier, T., and Brook, E.J., 2001, Timing of millennial-scale climate change in Antarctica and Greenland during the last glacial period.: Science, v. 291, no. 5501, p. 109-112, doi: 10.1126/science.291.5501.109. 
Blunier, T., Schwander, J., and Stauffer, B., 1997, Timing of the Antarctic Cold Reversal and the atmospheric $\mathrm{CO} \sim 2$ increase with respect to the Younger Dryas event: Geophysical

Bond, G., Heinrich, H., Broecker, W., and Labeyrie, L., 1992, Evidence for massive discharges of icebergs into the North Atlantic ocean during the last glacial period: Nature, v. 360 , no. 6401 , p. $245-249$, doi: $10.1038 / 360245 \mathrm{a} 0$.

Böhm, E., Lippold, J., Gutjahr, M., Frank, M., Blaser, P., Antz, B., Fohlmeister, J., Frank, N., Andersen, M.B., and Deininger, M., 2015, Strong and deep Atlantic meridional overturning circulation during the last glacial cycle: Nature, v. 517, no. 7532, p. 73-76, doi: 10.1038/nature14059.

Broecker, W., and Barker, S., 2007, A 190\%o drop in atmosphere's $\Delta 14 \mathrm{C}$ during the 'Mystery Interval' (17.5 to $14.5 \mathrm{kyr}$ ): Earth and Planetary Science Letters, v. 256, no. 1-2, p. 90-99, doi: 10.1016/j.epsl.2007.01.015.

Broecker, W.S., and Maier Reimer, E., 1992, The influence of air and sea exchange on the carbon isotope distribution in the sea: Global Biogeochemical Cycles, v. 6, no. 3, p. 315320, doi: 10.1029/92GB01672.

Brush, E., Fiduk, J.C., Love, F., Gibbs, P., Brink-Larsen, S., and Farrow, G., 2004, The Rio Doce Canyon System in the northern Espírito Santo Basin, offshore Brazil: a model for interpreting ancient deep-water sand transportation fairways: American Association of Petroleum Geologists Search and Discovery Article,, no. 30028.

Carmo, I. de O., and Vasconcelos, P., 2004, Geochronological evidence for pervasive Miocene weathering, Minas Gerais, Brazil: Earth Surface Processes and Landforms, v. 29, no. 11, p. 1303-1320, doi: 10.1002/esp.1090.

Carvalho, L., Jones, C., Posadas, A., Quiroz, R., Bookhagen, B., and Liebmann, B., 2012, Precipitation characteristics of the South American monsoon system derived from multiple datasets: Journal of Sedimentary Petrology, v. 25, no. 13, p. 4600-4620.

Carvalho, L.M.V., Jones, C., and Liebmann, B., 2004, The South Atlantic Convergence Zone: Intensity, Form, Persistence, and Relationships with Intraseasonal to Interannual Activity and Extreme Rainfall: Journal of Climate, v. 17, no. 1, p. 88-108, doi: 10.1175/15200442(2004)017<0088:TSACZI>2.0.CO;2.

Cheng, H., Sinha, A., Cruz, F.W., Wang, X., Edwards, R.L., d'Horta, F.M., Ribas, C.C., Vuille, M., Stott, L.D., and Auler, A.S., 2013, Climate change patterns in Amazonia and biodiversity: Nature Communications, v. 4, p. 1411-6, doi: 10.1038/ncomms2415.

Chiang, J., and Kushnir, Y., 2002, Deconstructing Atlantic Intertropical Convergence Zone variability: Influence of the local cross-equatorial sea surface temperature gradient and remote forcing from the eastern equatorial Pacific: Geology, doi: 10.1029/2000JD000307.

Chiang, J.C.H., and Friedman, A.R., 2012, Extratropical Cooling, Interhemispheric Thermal Gradients, and Tropical Climate Change: Annual Review of Earth and Planetary Science, 
v. 40, no. 1, p. 383-412, doi: 10.1146/annurev-earth-042711-105545.

Chiang, J.C.H., Biasutti, M., and Battisti, D.S., 2003, Sensitivity of the Atlantic Intertropical Convergence Zone to Last Glacial Maximum boundary conditions: Paleoceanography, v. 18, no. 4, p. n/a-n/a, doi: 10.1029/2003PA000916.

Chiessi, C.M., Mulitza, S., and Patzold, J., 2010, How different proxies record precipitation variability over southeastern South America: IOP Conference Series, , doi: 10.1088/17551315/9/1/012007.

Chiessi, C.M., Mulitza, S., Paul, A., and Patzold, J., 2008, South Atlantic interocean exchange as the trigger for the Bølling warm event: Geology, v. 36, no. 12, p. 919-922, doi: 10.1130/G24979A.1.

Clark, P.U., Pisias, N.G., Stocker, T.F., and Weaver, A.J., 2002, The role of the thermohaline circulation in abrupt climate change: Nature, v. 415, no. 6874, p. 863-869, doi: 10.1038/415863a.

Corliss, B.H., 1985, Microhabitats of benthic foraminifera within deep-sea sediments: Nature, v. 314, no. 6010, p. 435-438, doi: 10.1038/314435a0.

Craig, H., and Gordon, L.I., 1965, Deuterium and oxygen 18 variations in the ocean and the marine atmosphere, in Stable Isotopes in Oceanographic Studies and Paleotemperatures.

Cruz, F.W., Burns, S.J., Karmann, I., Sharp, W.D., Vuille, M., and Ferrari, J.A., 2006, A stalagmite record of changes in atmospheric circulation and soil processes in the Brazilian subtropics during the Late Pleistocene: Quaternary Science Reviews, v. 25, no. 21-22, p. 2749-2761, doi: 10.1016/j.quascirev.2006.02.019.

Cruz, F.W., Cruz, F.W., Burns, S.J., Karmann, I., Sharp, W.D., Vuille, M., Cardoso, A.O., Ferrari, J.A., Dias, P.L.S., and Viana, O., Jr., 2005a, Insolation-driven changes in atmospheric circulation over the past 116,000 years in subtropical Brazil: Nature, v. 434, no. 7029, p. 63-66, doi: 10.1038/nature03365.

Cruz, F.W., Karmann, I., Magdaleno, G.B., Coichev, N., and Viana, O., Jr., 2005b, Influence of hydrological and climatic parameters on spatial-temporal variability of fluorescence intensity and DOC of karst percolation waters in the Santana Cave System, Southeastern Brazil: Journal of Hydrology, v. 302, no. 1-4, p. 1-12, doi:

10.1016/j.jhydrol.2004.06.012.

Cruz, F.W., Vuille, M., Burns, S.J., Wang, X., and Cheng, H., 2009, Orbitally driven eastwest antiphasing of South American precipitation: Nature, v. 2, no. 3, p. 210-214, doi: 10.1038/ngeo444.

Curry, W.B., and Lohmann, G.P., 1982, Carbon isotopic changes in benthic foraminifera from the western South Atlantic: Reconstruction of glacial abyssal circulation patterns: Quaternary Research, v. 18, no. 2, p. 218-235, doi: 10.1016/0033-5894(82)90071-0.

Curry, W.B., and Oppo, D.W., 2005, Glacial water mass geometry and the distribution of $\delta 13 \mathrm{C}$ of $\Sigma \mathrm{CO} 2$ in the western Atlantic Ocean: Paleoceanography, v. 20, no. 1, doi: 10.1029/2004PA001021. 
da Silveira, I.C.A., Calado, L., de Castro, B.M., Cirano, M., Lima, J.A.M., and Mascarenhas, A.D.S., 2004, On the baroclinic structure of the Brazil Current-Intermediate Western Boundary Current system at $22^{\circ}-23^{\circ} \mathrm{S}$ : Geophysical Research Letters, v. 31, no. 14, p. L14308-5, doi: 10.1029/2004GL020036.

da Silveira, I.C.A., Schmidt, A.C.K., Campos, E.J.D., de Godoi, S.S., and Ikeda, Y., 2000, A Corrente do Brasil ao largo da costa leste brasileira: Revista Brasileira de Oceanografia, v. 48 , no. 2 , p. $171-183$.

de Almeida, F.F.M., Hasui, Y., Neves, B.B. de B., and Fuck, R.A., 1981, Brazilian structural provinces: An introduction: Earth-Science Reviews, v. 17, no. 1-2, p. 1-29, doi: 10.1016/0012-8252(81)90003-9.

de Oliveira, E.N., Knoppers, B.A., Lorenzzetti, J.A., Knoppers, B.A., Medeiros, P.R.P., Carneiro, M.E., and de Souza, W.F.L., 2012, A satellite view of riverine turbidity plumes on the NE-E Brazilian coastal zone: Brazilian Journal of Oceanography, v. 60, no. 3, p. 283-298, doi: 10.1590/S1679-87592012000300002.

Deplazes, Deplazes, G., Lückge, A., Peterson, L.C., Timmermann, A., Hamann, Y., Hughen, K.A., Röhl, U., Laj, C., Cane, M.A., Sigman, D.M., and Haug, G.H., 2013, Links between tropical rainfall and North Atlantic climate during the last glacial period: Nature Geoscience, v. 6, no. 3, p. 213-217, doi: 10.1038/ngeo1712.

Deschamps, P., Durand, N., Bard, E., Hamelin, B., Camoin, G., Thomas, A.L., Henderson, G.M., Okuno, J., and Yokoyama, Y., 2012, Ice-sheet collapse and sea-level rise at the Bølling warming 14,600 years ago: Nature, v. 483, no. 7391, p. 559-564, doi: 10.1038/nature10902.

Diaz, A.F., Studzinski, C.D., and Mechoso, C.R., 1998, Relationships between precipitation anomalies in Uruguay and southern Brazil and sea surface temperature in the Pacific and Atlantic Oceans: Journal of Climate, v. 11, no. 2, p. 251-271, doi: 10.1175/15200442(1998)011<0251:RBPAIU>2.0.CO;2.

Duplessy, J.C., Shackleton, N.J., Fairbanks, R.G., Labeyrie, L.D., Oppo, D.W., and Kallel, N., 1988, Deepwater source variations during the last climatic cycle and their impact on the global deepwater circulation: Paleoceanography, v. 3, no. 3, p. 343-360, doi: 10.1029/PA003i003p00343.

Duplessy, J.C., Shackleton, N.J., Matthews, R.K., and Prell, W., 1984, 13 C record of benthic foraminifera in the last interglacial ocean: Implications for the carbon cycle and the global deep water circulation: Quaternary Research, v. 21, no. 2, p. 225-243, doi: 10.1016/00335894(84)90099-1.

Ekau, W., and Knoppers, B.A., 1996, Sedimentation processes and Productivity in the Continental Shelf Waters off East and Northeast Brazil.:, 1-150 p.

Elmore, A.C., McClymont, E.L., Elderfield, H., Kender, S., Cook, M.R., Leng, M.J., Greaves, M., and Misra, S., 2015, Antarctic Intermediate Water properties since 400 ka recorded in infaunal (Uvigerina peregrina) and epifaunal (Planulina wuellerstorfi) benthic foraminifera: Earth and Planetary Science Letters, v. 428, p. 193-203, doi: 
10.1016/j.eps1.2015.07.013.

Emiliani, C., 1955, Pleistocene temperatures:.

Emílsson, I., 1961, The shelf and coastal waters off southern Brazil: Boletim do instituto oceanogràfico, v. 11, no. 2, p. 101-112, doi: 10.1590/S0373-55241961000100004.

EPICA Community Members, 2006, One-to-one coupling of glacial climate variability in Greenland and Antarctica: Nature, v. 444, no. 7116, p. 195-198, doi: 10.1038/nature05301.

Epstein, S., and Mayeda, T., 1953, Variation of O18 content of waters from natural sources: Geochimica et Cosmochimica Acta, v. 4, p. 213-224.

Erez, J., 1978, Vital effect on stable-isotope composition seen in foraminifera and coral skeletons: Nature, v. 273, no. 5659, p. 199-202, doi: 10.1038/273199a0.

Evans, D.L., Signorini, S.R., and Miranda, L.B., 1983, A Note on the Transport of the Brazil Current: Journal of Physical Oceanography, v. 13, no. 9, p. 1732-1738, doi: 10.1175/1520-0485(1983)013<1732:ANOTTO>2.0.CO;2.

Fontanier, C., Mackensen, A., and Jorissen, F.J., 2006, Stable oxygen and carbon isotopes of live benthic foraminifera from the Bay of Biscay: Microhabitat impact and seasonal variability: Marine ...,, doi: 10.1016/j.marmicro.2005.09.004.

França, A.M.C., 1979, Geomorfologia da margem continental leste brasileira e das bacias oceânicas adjacentes, in Série Projeto REMAC, p. 92-123.

França, M.C., Alves, I.C.C., Castro, D.F., Cohen, M.C.L., Rossetti, D.F., Pessenda, L.C.R., Lorente, F.L., Fontes, N.A., Junior, A.Á.B., Giannini, P.C.F., and Francisquini, M.I., 2015, A multi-proxy evidence for the transition from estuarine mangroves to deltaic freshwater marshes, Southeastern Brazil, due to climatic and sea-level changes during the late Holocene: Catena, v. 128, no. C, p. 155-166, doi: 10.1016/j.catena.2015.02.005.

Franke, J., Paul, A., and Schulz, M., 2008, Modeling variations of marine reservoir ages during the last 45000 years: Climate of the Past, v. 4, no. 2, p. 125-136.

Freeman, K.H., and Hayes, J.M., 1992, Fractionation of carbon isotopes by phytoplankton and estimates of ancient CO 2levels: Global Biogeochemical Cycles, v. 6, no. 2, p. 185198, doi: 10.1029/92GB00190.

Friedrich, M., Kromer, B., Kaiser, K.F., Spurk, M., Hughen, K.A., and Johnsen, S.J., 2001, High-resolution climate signals in the Bolling-Allerod Interstadial (Greenland Interstadial 1) as reflected in European tree-ring chronologies compared to marine varves and icecore records: Quaternary Science Reviews, v. 20, no. 11, p. 1223-1232, doi: 10.1016/S0277-3791(00)00148-7.

Ganachaud, A., and Wunsch, C., 2000, Improved estimates of global ocean circulation, heat transport and mixing from hydrographic data: Nature, v. 408, no. 6811, p. 453-457, doi: $10.1038 / 35044048$. 
Garcia, H. E., R. A. Locarnini, T. P. Boyer, J. I. Antonov, O.K. Baranova, M.M. Zweng, J.R. Reagan, D.R. Johnson (2014a). World Ocean Atlas 2013, Volume 3: Dissolved Oxygen, Apparent Oxygen Utilization, and Oxygen Saturation. S. Levitus, Ed., A. Mishonov Technical Ed.; NOAA Atlas NESDIS 75, 27 pp.

Garcia, H. E., R. A. Locarnini, T. P. Boyer, J. I. Antonov, O.K. Baranova, M.M. Zweng, J.R. Reagan, D.R. Johnson (2014b). World Ocean Atlas 2013, Volume 4: Dissolved Inorganic Nutrients (phosphate, nitrate, silicate). S. Levitus, Ed., A. Mishonov Technical Ed.; NOAA Atlas NESDIS 76, 25 pp.

Garreaud, R.D., Vuille, M., Compagnucci, R., and Marengo, J., 2009, Palaeogeography, Palaeoclimatology, Palaeoecology: Palaeogeography, Palaeoclimatology, Palaeoecology, v. 281, no. 3-4, p. 180-195, doi: 10.1016/j.palaeo.2007.10.032.

Govin, A., Holzwarth, U., Heslop, D., Keeling, L.F., Zabel, M., Mulitza, S., and Collins, J.A., 2012, Distribution of major elements in Atlantic surface sediments $\left(36^{\circ} \mathrm{N}-49^{\circ} \mathrm{S}\right)$ : Imprint of terrigenous input and continental weathering: Geochemistry, Geophysics, Geosystems, v. 13, no. 1, p. 1-23, doi: 10.1029/2011GC003785.

Govindaraju, K., Rubeska, I., and Paukert, T., 1994, Compilation of working values and sample description for 383 geostandards: Geostandards and Geoanalytical Research, v. 18, no. 1, p. 1-42, doi: 10.1111/j.1751-908X.1994.tb00502.x.

Gray, J.M., and Lowe, J.J., 1977, Studies in the Scottish Lateglacial Environment: Elsevier.

Grootes, P.M., and Stuiver, M., 1997, Oxygen 18/16 variability in Greenland snow and ice with 10- 3 to 105 -year time resolution: Journal of Geophysical Research: Oceans, v. 102, p. 26455-26470, doi: 10.1029/97JC00880.

Gunnell, Y., 1998, Passive margin uplifts and their influence on climatic change and weathering patterns of tropical shield regions: Global and Planetary Change, v. 18, no. 12, p. 47-57, doi: 10.1016/S0921-8181(98)00034-4.

Gyllencreutz, R., Mahiques, M.M., and Alves, D., 2010, Mid-to late-Holocene paleoceanographic changes on the southeastern Brazilian shelf based on grain size records: The Holocene, v. 20, no. 6, p. 863-875, doi: 10.1177/0959683610365936.

Haug, G.H., Hughen, K.A., Sigman, D.M., and Peterson, L.C., 2001, Southward migration of the intertropical convergence zone through the Holocene: Science.

Heezen, B.C., Tharp, M., and Ewing, M., 1959, The Floors of the Oceans I. The North Atlantic: Geological Society of America Special Papers, v. 65, p. 1-126, doi: 10.1130/SPE65-p1.

Holbourn, A., Kuhnt, W., and James, N., 2002, Late Pleistocene bryozoan reef mounds of the Great Australian Bight: Isotope stratigraphy and benthic foraminiferal record: Paleoceanography, v. 17, no. 3, p. 1-13, doi: 10.1029/2001PA000643.

Huang, K.F., Oppo, D.W., and Curry, W.B., 2014, Decreased influence of Antarctic intermediate water in the tropical Atlantic during North Atlantic cold events: Earth and Planetary Science Letters, v. 389, p. 200-208, doi: 10.1016/j.epsl.2013.12.037. 
Hughen, K.A., Overpeck, J.T., Peterson, L.C., and Trumbore, S., 1996, Rapid climate changes in the tropical Atlantic region during the last deglaciation: Nature, v. 380, no. 6569, p. 51-54, doi: 10.1038/380051a0.

Hughen, K.A., Southon, J.R., Lehman, S.J., and Overpeck, J.T., 2000, Synchronous radiocarbon and climate shifts during the last deglaciation: Science, v. 290, no. 5498, p. 1951-1954, doi: 10.1126/science.290.5498.1951.

Iversen, J., 1954, The late-glacial flora of Denmark and its relation to climate and soil: Danmarks geologiske undersøgelse.

Jaeschke, A., Rühlemann, C., Heil, G., Lohmann, G., and Arz, H.W., 2007, Coupling of millennial-scale changes in sea surface temperature and precipitation off northeastern Brazil with high-latitude climate shifts during the last glacial period: Paleoceanography, v. 22, no. 4, p. PA4206, doi: 10.1029/2006PA001391.

Jansen, J.H.F., Van der Gaast, S.J., Koster, B., and Vaars, A.J., 1998, CORTEX, a shipboard XRF-scanner for element analyses in split sediment cores: Marine Geology, v. 151, no. 14, p. 143-153, doi: 10.1016/S0025-3227(98)00074-7.

Jennerjahn, T.C., Ittekkot, V., Arz, H.W., Behling, H., Pätzold, J., and Wefer, G., 2004, Asynchronous terrestrial and marine signals of climate change during Heinrich events: Science, v. 306, no. 5705, p. 2236-2239, doi: 10.1126/science.1102490.

Killworth, P.D., 1983, Deep convection in the World Ocean: Reviews of Geophysics, v. 21, no. 1, p. 1, doi: 10.1029/RG021i001p00001.

Knoppers, B.A., Ekau, W., and Figueiredo, A.G., 1999, The coast and shelf of east and northeast Brazil and material transport: Geo-Marine Letters, v. 19, p. 171-178.

Koehler, P., Knorr, G., and Bard, E., 2014, Permafrost thawing as a possible source of abrupt carbon release at the onset of the Bolling/Allerod: Nature Communications, v. 5, doi: $10.1038 /$ ncomms 6520 .

Kroopnick, P.M., 1985, The distribution of 13C of $\Sigma \mathrm{CO} 2$ in the world oceans: Deep Sea Research Part A. Oceanographic Research Papers, v. 32, no. 1, p. 57-84, doi: 10.1016/0198-0149(85)90017-2.

Kuhlbrodt, T., Griesel, A., Montoya, M., Levermann, A., Hofmann, M., and Rahmstorf, S., 2007, On the driving processes of the Atlantic meridional overturning circulation: Reviews of Geophysics, v. 45, no. 2, p. RG2001, doi: 10.1029/2004RG000166.

Labeyrie, L.D., Duplessy, J.C., Duprat, J., Juillet-Leclerc, A., Moyes, J., Michel, E., Kallel, N., and Shackleton, N.J., 1992, Changes in the vertical structure of the North Atlantic Ocean between glacial and modern times: Quaternary Science Reviews, v. 11, no. 4, p. 401-413, doi: 10.1016/0277-3791(92)90022-Z.

Lambeck, K., and Chappell, J., 2001, Sea Level Change Through the Last Glacial Cycle: Science, v. 292, no. 5517, p. 679-686, doi: 10.1126/science.1059549.

Langway, C.C., Oeschger, H., and Dansgaard, W., 1985, The Greenland Ice Sheet Program in 
Perspective: American Geophysical Union, Washington, D. C.

Lea, D.W., Pak, D.K., Peterson, L.C., and Hughen, K.A., 2003, Synchroneity of Tropical and High-Latitude Atlantic Temperatures over the Last Glacial Termination: Science, v. 301, no. 5638, p. 1361-1364, doi: 10.1126/science. 1088470.

Lenters, J.D., and Cook, K.H., 1997, On the origin of the Bolivian high and related circulation features of the South American climate: Journal of the Atmospheric Sciences, v. 54, no. 5, p. 656-678, doi: 10.1175/1520-0469(1997)054<0656:OTOOTB>2.0.CO;2.

Liebmann, B., Kiladis, G.N., Marengo, J.A., Ambrizzi, T., and Glick, J.D., 1999, Submonthly convective variability over South America and the South Atlantic convergence zone: Journal of Climate, v. 12, no. 7, p. 1877-1891, doi: 10.1175/1520-0442.

Lippold, J. et al., 2009 Does sedimentary ${ }^{231} \mathrm{~Pa} /{ }^{230} \mathrm{Th}$ from the Bermuda Rise monitor past Atlantic meridional overturning circulation? Geophysical Research Letters. 36, L12601.

Locarnini, A, R., Mishonov, A.V., Antonov, J.I., Boyer, T.P., Garcia, H.E., Baranova, O.K., Zweng, M.M., Paver, C.R., Reagan, J.R., Johnson, D.R., Hamilton, M., and Seidov, D., 2013, World Ocean Atlas 2013, Volume 1: Temperature:, 1-48 p.

Lund, D.C., Tessin, A.C., Hoffman, J.L., and Schmittner, A., 2015, Southwest Atlantic water mass evolution during the last deglaciation: Paleoceanography, v. 30, no. 5, p. 477-494, doi: 10.1002/2014PA002657.

Lynch-Stieglitz, J., Adkins, J.F., Curry, W.B., Dokken, T., Hall, I.R., Herguera, J.C., Hirschi, J.J.M., Ivanova, E.V., Kissel, C., Marchal, O., Marchitto, T.M., McCave, I.N., McManus, J.F., Mulitza, S., et al., 2007, Atlantic meridional overturning circulation during the Last Glacial Maximum: Science, v. 316, no. 5821, p. 66-69, doi: 10.1126/science.1137127.

Lynch-Stieglitz, J., Curry, W.B., Oppo, D.W., Ninneman, U.S., Charles, C.D., and Munson, J., 2006, Meridional overturning circulation in the South Atlantic at the last glacial maximum: Geochemistry, Geophysics, Geosystems, v. 7, no. 10, p. 14, doi: 10.1029/2005GC001226.

Lynch-Stieglitz, J., Fairbanks, R.G., and Charles, C.D., 1994, Glacial-interglacial history of Antarctic Intermediate Water: relative strengths of Antarctic versus Indian Ocean sources: Paleoceanography.

Lynch-Stieglitz, J., Schmidt, M.W., Henry, L.G., and Curry, W.B., 2014, Muted change in Atlantic overturning circulation over some glacial-aged Heinrich events: Nature Geoscience, v. 7, p. 144-150, doi: 10.1038/ngeo2045.

Lynch-Stieglitz, J., van Geen, A., and Fairbanks, R.G., 1996, Interocean exchange of glacial North Atlantic Intermediate Water: Evidence from subantarctic $\mathrm{Cd} / \mathrm{Ca}$ and carbon isotope measurements: Paleoceanography, v. 11, no. 2, p. 191-201, doi: 10.1029/95PA03772.

Mackensen, A., Hubberten, H.W., Bickert, T., Fischer, G., and Fütterer, D.K., 1993, The $\delta 13 \mathrm{C}$ in benthic foraminiferal tests of Fontbotia wuellerstorfi (Schwager) relative to the $\delta 13 \mathrm{C}$ of dissolved inorganic carbon in Southern Ocean Deep Water: Implications for 
glacial ocean circulation models: Paleoceanography, v. 8, no. 5, p. 587-610, doi: 10.1029/93PA01291.

Maia, M.A.M., 2013, Geodiversidade das áreas adjacentes à Cadeia Submarina de VitóriaTrindade: construção e aplicação de um modelo de compartimentação em macroescala do assoalho oceânico: Instituto de Geociências, Universidade Federal do Rio de Janeiro, 173 p.

Makou, M.C., Oppo, D.W., and Curry, W.B., 2010, South Atlantic intermediate water mass geometry for the last glacial maximum from foraminiferal $\mathrm{Cd} / \mathrm{Ca}$ : Paleoceanography, $\mathrm{v}$. 25, no. 4, p. PA4101-7, doi: 10.1029/2010PA001962.

Marchitto, T.M., Curry, W.B., Lynch-Stieglitz, J., Bryan, S.P., Cobb, K.M., and Lund, D.C., 2014, Improved oxygen isotope temperature calibrations for cosmopolitan benthic foraminifera: Geochimica et Cosmochimica Acta, v. 130, no. C, p. 1-11, doi: 10.1016/j.gca.2013.12.034.

Marchitto, T.M., Lehman, S.J., Ortiz, J.D., Flückiger, J., and van Geen, A., 2007, Marine Radiocarbon Evidence for the Mechanism of Deglacial Atmospheric CO2 Rise: Science, v. 316, no. 5830, p. 1456-1459, doi: 10.1126/science.1138679.

Marcott, S.A., Bauska, T.K., WAIS Divide Project Members, Steig, E.J., Rosen, J.L., Cuffey, K.M., Fudge, T.J., Severinghaus, J.P., Ahn, J., Kalk, M.L., McConnell, J.R., Sowers, T., Taylor, K.C., White, J.W.C., et al., 2014, Centennial-scale changes in the global carbon cycle during the last deglaciation: Nature, v. 514, no. 7524, p. 616-619, doi: 10.1038 /nature13799.

Marengo, J.A., Liebmann, B., Kousky, V.E., Filizola, N.P., and Wainer, I., 2001, Onset and end of the rainy season in the Brazilian Amazon Basin: Journal of Climate, v. 14, p. 833852.

Marques, M., da Costa, M.F., Mayorga, M.I. de O., and Pinheiro, P.R.C., 2004, Water environments: anthropogenic pressures and ecosystem changes in the atlantic drainage basins of Brazil: AMBIO: A Journal of the Human Environment, v. 33, no. 1, p. 68-77, doi: 10.1579/0044-7447-33.1.68.

Massé, L., Faugères, J.C., Pujol, C., Pujos, A., LaBeyrie, L.D., and Bernat, M., 1996, Sediment flux distribution in the Southern Brazil Basin during the late Quaternary: The role of deep-sea currents: Sedimentology, v. 43, no. 1, p. 115-132, doi: 10.1111/j.13653091.1996.tb01463.x.

McCorkle, D.C., Keigwin, L.D., Corliss, B.H., and Emerson, S.R., 1990, Correction to "The influence of microhabitats on the carbon isotopic composition of deep-sea benthic foraminifera": Paleoceanography, v. 5, no. 3, p. 295-295, doi: 10.1029/PA005i003p00295.

McManus, J.F., Francois, R., Gherardi, J.M., Keigwin, L.D., and Brown-Leger, S., 2004, Collapse and rapid resumption of Atlantic meridional circulation linked to deglacial climate changes: Nature, v. 428, no. 6985, p. 834-837, doi: 10.1038/nature02494. 
Mix, A., Bard, E., and Schneider, R., 2001, Environmental processes of the ice age: land, oceans, glaciers (EPILOG): Quaternary Science Reviews, v. 20, no. 4, p. 627-657, doi: 10.1016/S0277-3791(00)00145-1.

Mook, W.G., Bommerson, J.C., and Staverman, W.H., 1974, Carbon Isotope Fractionation Between Dissolved Bicarbonate and Gaseous Carbon-Dioxide: Earth and Planetary Science Letters, v. 22, no. 2, p. 169-176.

Mulitza, S., Boltovskoy, D., Donner, B., Meggers, H., Paul, A., and Wefer, G., 2003, Temperature: $\delta 18 \mathrm{O}$ relationships of planktonic foraminifera collected from surface waters: Palaeogeography, Palaeoclimatology, Palaeoecology, v. 202, no. 1-2, p. 143-152, doi: 10.1016/S0031-0182(03)00633-3.

Muratli, J.M., Chase, Z., Mix, A.C., and McManus, J., 2010, Increased glacial-age ventilation of the Chilean margin by Antarctic Intermediate Water: Nature Geoscience, v. 3, no. 1, p. 23-26, doi: 10.1038/NGEO715.

Nace, T.E., Baker, P.A., Dwyer, G.S., Silva, C.G., Rigsby, C.A., Burns, S.J., Giosan, L., OttoBliesner, B., Liu, Z., and Zhu, J., 2014, The role of North Brazil Current transport in the paleoclimate of the Brazilian Nordeste margin and paleoceanography of the western tropical Atlantic during the late Quaternary: Palaeogeography, Palaeoclimatology, Palaeoecology, v. 415, p. 3-13, doi: 10.1016/j.palaeo.2014.05.030.

Ninnemann, U.S., and Charles, C.D., 2002, Changes in the mode of Southern Ocean circulation over the last glacial cycle revealed by foraminiferal stable isotopic variability: Earth and Planetary Science Letters, v. 201, no. 2, p. 383-396, doi: 10.1016/S0012$821 \mathrm{X}(02) 00708-2$.

Ninnemann, U.S., and Charles, C.D., 1997, Regional differences in Quaternary subantarctic nutrient cycling: Link to intermediate and deep water ventilation: Paleoceanography, $\mathrm{v}$. 12, no. 4, p. 560-567, doi: 10.1029/97PA01032.

Nobre, P., and Shukla, J., 1996, Variations of sea surface temperature, wind stress, and rainfall over the tropical Atlantic and South America: Journal of Climate, v. 9, no. 10, p. 2464-2479, doi: 10.1175/1520-0442(1996)009<2464:VOSSTW>2.0.CO;2.

Oppo, D.W., and Horowitz, M., 2000, Glacial deep water geometry: South Atlantic benthic foraminiferal $\mathrm{Cd} / \mathrm{Ca}$ and $\delta 13 \mathrm{C}$ evidence: Paleoceanography, v. 15, no. 2, p. 147-160, doi: 10.1029/1999PA000436.

Oppo, D.W., Curry, W.B., and McManus, J.F., 2015, What do benthic $\delta 13 \mathrm{C}$ and $\delta 18 \mathrm{O}$ data tell us about Atlantic circulation during Heinrich Stadial 1?: Paleoceanography,, doi: 10.1002/(ISSN)1944-9186.

Pahnke, K., Goldstein, S.L., and Hemming, S.R., 2008, Abrupt changes in Antarctic Intermediate Water circulation over the past 25,000 years: Nature Geoscience, v. 1, no. 12, p. 870-874, doi: 10.1038/ngeo360.

Parrenin, F., Masson-Delmotte, V., Köhler, P., and Raynaud, D., 2013, Synchronous change of atmospheric $\mathrm{CO} 2$ and Antarctic temperature during the last deglacial warming: Science,, doi: 10.1126/science.1230969. 
Pätzold, J., Arz, H.W., Absher, T.M., Barreto, A.V., Bertilao da Silva, L.F., Draschba, S., Figueiredo, A.G., Freire, G.S.S., Gomez, A.S., Morais, J.O., Roscher, N.A., Rosenboom, W., Rühlermann, C., Souza, S.H.M., et al., 1996, Report and preliminary results of RV Victor Hensen cruise JOPS II: leg 6 Fortaleza - Recife and leg 8 Vitória -Vitória: Berichte, Fachbereich Geowissenschaften 76, 1-98 p.

Peel, M.C., Finlayson, B.L., and McMahon, T.A., 2007, Updated world map of the KöppenGeiger climate classification: Hydrology and Earth System Sciences Discussions, v. 4, no. 2, p. 439-473.

Peterson, C.D., Lisiecki, L.E., and Stern, J.V., 2014, Deglacial whole-ocean $\delta 13 C$ change estimated from 480 benthic foraminiferal records: Paleoceanography, v. 29, no. 6, p. 115, doi: 10.1002/2013PA002552.

Peterson, L.C., Haug, G.H., Hughen, K.A., and Röhl, U., 2000, Rapid changes in the hydrologic cycle of the tropical Atlantic during the last glacial.: Science, v. 290, no. 5498, p. 1947-1951, doi: 10.1126/science.290.5498.1947.

Peterson, R.G., and Stramma, L., 1991, Upper-level circulation in the South Atlantic Ocean: Progress in Oceanography, v. 26, no. 1, p. 1-73, doi: 10.1016/0079-6611(91)90006-8.

Petit, J.R., Jouzel, J., Raynaud, D., Barkov, N.I., and Barnola, J.M., 1999, Climate and atmospheric history of the past 420,000 years from the Vostok ice core, Antarctica: Nature.

Rahmstorf, S., 2002, Ocean circulation and climate during the past 120,000 years: Nature, v. 419, no. 6903, p. 207-214, doi: 10.1038/nature01090.

Rahmstorf, S., Box, J.E., Feulner, G., Mann, M.E., Robinson, A., Rutherford, S., and Schaffernicht, E.J., 2015, Exceptional twentieth-century slowdown in Atlantic Ocean overturning circulation: Nature Climate Change, v. 5, no. 5, p. 475-480, doi: 10.1038/nclimate2554.

Raia, A., and Cavalcanti, I.F.A., 2008, The Life Cycle of the South American Monsoon System: Journal of Climate, v. 21, no. 23, p. 6227-6246, doi: 10.1175/2008JCLI2249.1.

Rasmussen,T.,Oppo,D.,Thomsen,E.\&Lehman,S, 2003.Deep sea records from the southeast Labrador Sea: ocean circulation changes and ice-rafting events during the last 160,000 years. Paleoceanography $18,1081$.

Rasmussen, S.O., Andersen, K.K., Svensson, A.M., Steffensen, J.P., Vinther, B.M., Clausen, H.B., Siggaard-Andersen, M.L., Johnsen, S.J., Larsen, L.B., Dahl-Jensen, D., Bigler, M., Röthlisberger, R., Fischer, H., Goto-Azuma, K., et al., 2006, A new Greenland ice core chronology for the last glacial termination: Journal of Geophysical Research: Oceans, v. 111, no. D6, p. D06102-16, doi: 10.1029/2005jd006079.

Rasmussen, S.O., Bigler, M., Blockley, S.P., Blunier, T., Buchardt, S.L., Clausen, H.B., Cvijanovic, I., Dahl-Jensen, D., Johnsen, S.J., Fischer, H., Gkinis, V., Guillevic, M., Hoek, W.Z., Lowe, J.J., et al., 2014, A stratigraphic framework for abrupt climatic changes during the Last Glacial period based on three synchronized Greenland ice-core 
records: refining and extending the INTIMATE event stratigraphy: Quaternary Science Reviews, v. 106, no. C, p. 14-28, doi: 10.1016/j.quascirev.2014.09.007.

Reid, J.L., Nowlin, W.D., Jr, and Patzert, W.C., 1977, On the characteristics and circulation of the southwestern Atlantic Ocean: Journal of Physical Oceanography, v. 7, no. 1, p. 62 91, doi: 10.1175/1520-0485(1977)007<0062:OTCACO>2.0.CO;2.

Reimer, P.J., Bard, E., Bayliss, A., Beck, J.W., Blackwell, P.G., Ramsey, C.B., Buck, C.E., Cheng, H., Edwards, R.L., Friedrich, M., Grootes, P.M., Guilderson, T.P., Haflidason, H., Hajdas, I., et al., 2013, IntCal13 and Marine13 radiocarbon age calibration curves 050,000 years cal BP: Radiocarbon, v. 55, no. 4, p. 1869-1887, doi: 10.2458/azu_js_rc.55.16947.

Rickaby, R.E.M., Elderfield, H., and Elderfield, H., 2005, Evidence from the high-latitude North Atlantic for variations in Antarctic Intermediate water flow during the last deglaciation: Geochemistry, Geophysics, Geosystems, v. 6, no. 5, p. n/a-n/a, doi: 10.1029/2004GC000858.

Rossetti, D. de F., Polizel, S.P., Cohen, M.C.L., and Pessenda, L.C.R., 2015, Late Pleistocene-Holocene evolution of the Doce River delta, southeastern Brazil: Implications for the understanding of wave-influenced deltas: Marine Geology, v. 367, p. 171-190, doi: 10.1016/j.margeo.2015.05.012.

Sabine, C.L., Feely, R.A., Gruber, N., Key, R.M., Lee, K., Bullister, J.L., Wanninkhof, R., Wong, C.S., Wallace, D., Tilbrook, B., Millero, F.J., Peng, T.H., Kozyr, A., Ono, T., et al., 2004, The oceanic sink for anthropogenic CO2: Science, v. 305, no. 5682, p. 367371, doi: 10.1126/science.1097403.

Sarnthein, M., Stattegger, K., Dreger, D., Erlenkeuser, H., Grootes, P., Haupt, B.J., Jung, S., Kiefer, T., Kuhnt, W., Pflaumann, U., Schäfer-Neth, C., Schulz, H., Schulz, M., Seidov, D., et al., 2000, Fundamental Modes and Abrupt Changes in North Atlantic Circulation and Climate over the last $60 \mathrm{ky}$ - Concepts, Reconstruction and Numerical Modeling, in Schäfer, P., Ritzrau, W., Schlüter, M., and Thiede, J. eds., The Northern North Atlantic, Springer Berlin Heidelberg, Berlin, Heidelberg, p. 365-410.

Sarnthein, M., Winn, K., Jung, S.J.A., Duplessy, J.-C., Labeyrie, L., Erlenkeuser, H., and Ganssen, G., 1994, Changes in East Atlantic Deepwater Circulation over the last 30,000 years: eight time slice reconstructions: Paleoceanography, v. 9, no. 2, p. 209-267, doi: 10.1029/93PA03301.

Schlitzer, R. 2015. Ocean Data View, http://odv.awi.de.

Schmid, C., Podestá, G., and Zenk, W., 1995, The Vitória Eddy and its relation to the Brazil Current: Journal of Physical Oceanography, v. 25, p. 2532-2547.

Schmiedl, G., and Mackensen, A., 2006, Multispecies stable isotopes of benthic foraminifers reveal past changes of organic matter decomposition and deepwater oxygenation in the Arabian Sea: Paleoceanography, v. 21, no. 4, p. n/a-n/a, doi: 10.1029/2006PA001284.

Schmiedl, G., Pfeilsticker, M., Hemleben, C., and Mackensen, A., 2004, Environmental and 
biological effects on the stable isotope composition of recent deep-sea benthic foraminifera from the western Mediterranean Sea: Marine Micropaleontology, v. 51, no. 1-2, p. 129-152, doi: 10.1016/j.marmicro.2003.10.001.

Schneider, T., Bischoff, T., and Haug, G.H., 2014, Migrations and dynamics of the intertropical convergence zone: Nature, v. 513, no. 7516, p. 45-53, doi: 10.1038/nature13636.

Schrag, D.P., Adkins, J.F., McIntyre, K., Alexander, J.L., Hodell, D.A., Charles, C.D., and McManus, J.F., 2002, The oxygen isotopic composition of seawater during the Last Glacial Maximum: Quaternary Science Reviews, v. 21, no. 1-3, p. 331-342, doi: 10.1016/S0277-3791(01)00110-X.

Schreiner, S., de Souza, M.B.F.M., and Migliorelli, J.P.R., 2009, Modelo digital da geomorfologia do fundo oceânico do centro-sul da Bacia do Espírito Santo e norte da Bacia de Campos: Boletim de Geociências da Petrobrás, v. 17, no. 2, p. 365-369.

Seluchi, M.E., Saulo, A.C., Nicolini, M., and Satyamurty, P., 2003, The northwestern Argentinean low: A study of two typical events: Monthly Weather Review, v. 131, no. 10, p. 2361-2378.

Shackleton, N.J., 1977, Carbon-13 in Uvigerina: Tropical Rainforest History and the Equatorial Pacific Carbonate Dissolution Cycles, in The Fate of Fossil Fuel CO2 in the Oceans, Springer US, Boston, MA, p. 401-427.

Siegenthaler, U., and Wenk, T., 1984, Rapid Atmospheric Co2 Variations and Ocean Circulation: Nature, v. 308, no. 5960, p. 624-626, doi: 10.1038/308624a0.

Sinha, A., Cannariato, K.G., Stott, L.D., Li, H.-C., You, C.-F., Cheng, H., Edwards, R.L., and Singh, I.B., 2005, Variability of Southwest Indian summer monsoon precipitation during the Bølling-Ållerød: Geology, v. 33, no. 10, p. 813-5, doi: 10.1130/G21498.1.

Sortor, R., 2012, No Evidence for a Deglacial Intermediate Water $\Delta 14 \mathrm{C}$ Anomaly in the Southwest Atlantic: Earth and Planetary Science Letters.

Souza, W.F.L., and Knoppers, B.A., 2003, Fluxos de água e sedimentos a costa leste do Brasil: relações entre a tipologia e pressões antrópicas: Geochimica Brasiliensis, v. 17, no. 1 , p. 57-74.

Stenni, B., Masson-Delmotte, V., Johnsen, S., Jouzel, J., Longinelli, A., Monnin, E., Röthlisberger, R., and Selmo, E., 2001, An Oceanic Cold Reversal During the Last Deglaciation: Science, v. 293, no. 5537, p. 2074-2077.

Stramma, L., 1991, Geostrophic Transport of the South Equatorial Current in the Atlantic: Journal of Marine Research, v. 49, no. 2, p. 281-294, doi: $10.1357 / 002224091784995864$.

Stramma, L., and England, M.H., 1999, On the water masses and mean circulation of the South Atlantic Ocean: Journal of Geophysical Research: Oceans (1978-2012), v. 104, no. C9, p. 20863-20883, doi: 10.1029/1999JC900139. 
Stríkis, N.M., Chiessi, C.M., Cruz, F.W., Vuille, M., Cheng, H., Barreto, E.A. de S., Mollenhauer, G., Karsten, S., Karmann, I., Bernal, J.P., and Sales, H.D.R., 2015, Timing and structure of Mega-SACZ events during Heinrich Stadial 1: Geophysical Research Letters, v. 42, p. 1-8, doi: 10.1002/(ISSN)1944-8007.

Stuiver, M., and Reimer, P.J., 1993, Extended ${ }^{14} \mathrm{C}$ data base and revised CALIB $3.0{ }^{14} \mathrm{C}$ age calibration program: Radiocarbon, v. 35, no. 1, p. 215-230.

Summerhayes, C.P., de Melo, U., and Barretto, H.T., 1976, The influence of upwelling on suspended matter and shelf sediments off southeastern Brazil: Journal of Sedimentary Petrology, v. 46, p. 819-828.

Talley, L.D., 1996, Antarctic Intermediate Water in the South Atlantic, in The South Atlantic, Springer Berlin Heidelberg, Berlin, Heidelberg, p. 219-238.

Tessin, A.C., and Lund, D.C., 2013, Isotopically depleted carbon in the mid-depth South Atlantic during the last deglaciation: Paleoceanography, v. 28, no. 2, p. 296-306, doi: 10.1002/palo.20026.

Thiagarajan, N., Subhas, A.V., Southon, J.R., Eiler, J.M., and Adkins, J.F., 2014, Abrupt preBølling-Allerød warming and circulation changes in the deep ocean: Nature, v. 511, no. 7507, p. 75-78, doi: 10.1038/nature13472.

Thompson, L., Davis, M., Mosley-Thompson, E., Sowers, T., Henderson, K., Zagorodnov, V., Lin, P., Mikhalenko, V., Campen, R., Bolzan, J., Cole-Dai, J., and Francou, B., 1998, A 25,000-year tropical climate history from bolivian ice cores: Science, v. 282, no. 5395, p. 1858-1864, doi: 10.1126/science.282.5395.1858.

Tintelnot, M., 1995, Transport and deposition of fine-grained sediments on the Brazilian continental shelf as revealed by clay mineral distribuition: Ruprecht-Karls-Universität Heidelberg, 296 p.

Tintelnot, M., Brichta, A., and Morais, J.O., 1998, Clay mineralogy of river sediments on the Brazilian coast: Jahrestagung der DTTG 1998, v. 6, p. 1-15.

Tsuchiya, M., and Talley, L.D., 1994, Water-mass distribuitions in the western South Atlantic; A section from South Georgia Island (54S) northward across the equator: Journal of Marine Research, v. 52, p. 55-81.

Vera, C., Higgins, W., Amador, J., and Ambrizzi, T., 2006, Toward a unified view of the American monsoon systems: Journal of Sedimentary Petrology, v. 19, no. 20, p. $4977-$ 5000, doi: 10.1175/JCLI3896.1.

Waelbroeck, C., Labeyrie, L., Michel, E., Duplessy, J.C., McManus, J.F., Lambeck, K., Balbon, E., and Labracherie, M., 2002, Sea-level and deep water temperature changes derived from benthic foraminifera isotopic records: Quaternary Science Reviews, v. 21, p. 295-305.

Waelbroeck, C., Skinner, L.C., Labeyrie, L., Duplessy, J.C., Michel, E., Vazquez Riveiros, N., Gherardi, J.M., and Dewilde, F., 2011, The timing of deglacial circulation changes in the Atlantic: Paleoceanography, v. 26, no. 3, p. n/a-n/a, doi: 10.1029/2010PA002007. 
WAIS Divide Project Members, 2015, Precise interpolar phasing of abrupt climate change during the last ice age: Nature, v. 520, no. 7549, p. 661-665, doi: 10.1038/nature14401.

Wang, X., Auler, A.S., Edwards, R.L., Cheng, H., Cristalli, P.S., Smart, P.L., Richards, D.A., and Shen, C.-C., 2004, Wet periods in northeastern Brazil over the past $210 \mathrm{kyr}$ linked to distant climate anomalies: Nature, v. 432, no. 7018, p. 740-743, doi: 10.1038/nature03067.

Wang, X., Auler, A.S., Edwards, R.L., Cheng, H., Ito, E., Wang, Y., Kong, X., and Solheid, M., 2007, Millennial-scale precipitation changes in southern Brazil over the past 90,000 years: Geophysical Research Letters, v. 34, no. 23, p. L23701, doi: 10.1029/2007GL031149.

Wang, X., Cruz, F.W., Auler, A.S., Cheng, H., and Edwards, R.L., 2008a, Millenial-scale climate variability recorded in Brazilian speleothems: PAGES News, v. 16, p. 1-2.

Wang, Y., Cheng, H., Edwards, R.L., Kong, X., Shao, X., Chen, S., Wu, J., Jiang, X., Wang, X., and An, Z., 2008b, Millennial- and orbital-scale changes in the East Asian monsoon over the past 224,000 years: Nature, v. 451, no. 7182, p. 1090-1093, doi: 10.1038 /nature06692.

Wang, Y.J., Cheng, H., Edwards, R.L., An, Z.S., Wu, J.Y., Shen, C.C., and Dorale, J.A., 2001, A high-resolution absolute-dated late Pleistocene Monsoon record from Hulu Cave, China.: Science, v. 294, no. 5550, p. 2345-2348, doi: 10.1126/science.1064618.

Weber, M.E., Clark, P.U., Kuhn, G., Timmermann, A., Sprenk, D., Gladstone, R., Zhang, X., Lohmann, G., Menviel, L., Chikamoto, M.O., Friedrich, T., and Ohlwein, C., 2014, Millennial-scale variability in Antarctic ice-sheet discharge during the last deglaciation: Nature, v. 510, no. 7503, p. 134-138, doi: 10.1038/nature13397.

Weldeab, S., Schneider, R.R., and Kölling, M., 2006, Deglacial sea surface temperature and salinity increase in the western tropical Atlantic in synchrony with high latitude climate instabilities: Earth and Planetary Science Letters, v. 241, no. 3-4, p. 699-706, doi: 10.1016/j.epsl.2005.11.012.

Weltje, G.J., and Tjallingii, R., 2008, Calibration of XRF core scanners for quantitative geochemical logging of sediment cores: Theory and application: Earth and Planetary Science Letters, v. 274, no. 3-4, p. 423-438, doi: 10.1016/j.eps1.2008.07.054.

Wohlfarth, B., 1996, The chronology of the last termination: A review of radiocarbon-dated, high-resolution terrestrial stratigraphies: Quaternary Science Reviews, v. 15, no. 4, p. 267-284, doi: 10.1016/0277-3791(96)00001-7.

Xie, R.C., Marcantonio, F., and Schmidt, M.W., 2012, Deglacial variability of Antarctic Intermediate Water penetration into the North Atlantic from authigenic neodymium isotope ratios: Paleoceanography,, p. PA3221, doi: 10.1029/2012PA002337.

Zahn, R., and Stüber, A., 2002, Suborbital intermediate water variability inferred from paired benthic foraminiferal $\mathrm{Cd} / \mathrm{Ca}$ and $\delta 13 \mathrm{C}$ in the tropical West Atlantic and linking with North Atlantic climates: Earth and Planetary Science Letters, v. 200, no. 1-2, p. 191-205, doi: 10.1016/s0012-821x(02)00613-1. 
Zahn, R., Winn, K., and Sarnthein, M., 1986, Benthic foraminiferal $\delta 13 \mathrm{C}$ and accumulation rates of organic carbon: Uvigerina peregrina group and Cibicidoides wuellerstorfi: Paleoceanography.

Zhang, Y., Chiessi, C.M., Mulitza, S., Zabel, M., Trindade, R.I.F., Hollanda, M.H.B.M., Dantas, E.L., Govin, A., Tiedemann, R., and Wefer, G., 2015, Origin of increased terrigenous supply to the NE South American continental margin during Heinrich Stadial 1 and the Younger Dryas: Earth and Planetary Science Letters,, p. 1-12, doi: 10.1016/j.eps1.2015.09.054.

Zweng, M.M, J.R. Reagan, J.I. Antonov, R.A. Locarnini, A.V. Mishonov, T.P. Boyer, H.E. Garcia, O.K. Baranova, D.R. Johnson, D.Seidov, M.M. Biddle (2013). World Ocean Atlas 2013, Volume 2: Salinity. S. Levitus, Ed., A. Mishonov Technical Ed.; NOAA Atlas NESDIS 74, 39 pp. 
South American summer monsoon decreased intensity related to the Bølling-Allerød

interstadial

\section{Abstract}

4 The last deglaciation was marked by large-scale and rapid changes in rainfall over

5 the tropics. Previous studies have correlated pulses of increased terrigenous input off semi-

6 arid northeastern South America with abrupt cold events in the high latitudes of the

7 Northern Hemisphere. However, deglacial climate changes in other areas of South America

8 are still not resolved. Here we reconstruct deglacial (23-11.5 cal ka BP) continental

9 conditions over eastern Brazil based on (i) Ti/Ca of a radiocarbon dated marine sediment

10 core as a proxy for Doce River (draining eastern Brazil) terrigenous input, and (ii) $\delta^{18} \mathrm{O}$ of a

11 suite of U-Th dated stalagmites from eastern Brazil. Our marine core was recovered from

$121100 \mathrm{~m}$ water depth on the tropical Brazilian continental slope, while our stalagmites come

13 from Lapa Sem Fim Cave. Both the Doce River and Lapa Sem Fim Cave are located in the

14 highly populated and economically active eastern Brazil, where most of the rainfall is

15 related to the activity of the South American Monsoon System (SAMS). The Ti/Ca record

16 is relatively stable, showing high proportions of $\mathrm{Ti}$ in relationship to $\mathrm{Ca}$ throughout the

17 deglacial, with a major excursion towards lower values, indicating a decrease in terrigenous

18 input, synchronous to the $\mathrm{B} \emptyset$ lling-Allerød. Interestingly, speleothem $\delta^{18} \mathrm{O}$ also displays this

19 major excursion, by recording less negative values. Together, our results suggest a major

20 decrease in precipitation, likely related to a weakening of the SAMS. We further compared

21 our results with the output of the SYNTRACE run of the CCSM3 fully-coupled climate

22 model with transient forcing for the last deglaciation. Geochemical records and model

23 output show consistent results and suggest that eastern Brazil experienced the driest period

24 of the whole last deglaciation during the Bølling-Allerød and that this dry spell was indeed

25 related to a decreased SAMS intensity. 


\section{Introduction}

Heinrich stadials (HS) impacted continental tropical climates mainly through changes in intensity of monsoon systems. In South America (SA), during these events, a 30 significant decrease in North Atlantic sea surface temperatures (SST) shifted the 31 Intertropical Convergence Zone (ITCZ) location southwards, strengthening the South American Summer Monsoon (SASM) (Wang et al., 2004). Modeling efforts are consistent with the hypothesis that AMOC variations, and their effect on heat transport, hemispheric SST patterns, and ITCZ position, can be invoked to explain the strong covariation observed between Greenland and Cariaco Basin proxy records (e.g., Chiang and Friedman, 2012; Hughen et al., 1996; L. C. Peterson et al., 2000).

In Brazil, the first study on the impact of millennial-scale abrupt events was (Arz et al., 1999; 1998), based in terrigenous input and planktonic foraminifera $\delta^{18} \mathrm{O}$ off $\mathrm{NE}$ Brazil. They showed increased terrigenous input during Heinrich events due to a southward shift of the ITCZ. Terrigenous materials deposited off tropical and subtropical eastern SA are delivered to the ocean via fluvial pathways, which are highly sensitive to climate change (Zhang et al., 2015). High concentrations of terrigenous elements and low calcium concentrations along the tropical and subtropical South American continental margins reflect the dominance of terrigenous input in these regions (Govin et al., 2012). Since Arz et al. (1998), a number of studies have used major element composition of marine sediment cores to trace changes in terrigenous input into the Atlantic (Arz et al., 1999; 1998; Bender et al., 2013; Chiessi et al., 2010; 2009; Govin et al., 2014; Haug et al., 2001; Jaeschke et al., 2007; L. C. Peterson et al., 2000; Stríkis et al., 2015; Voigt et al., 2013; Zhang et al., 2015). Yet, the $23-7^{\circ} \mathrm{S}$ sector of the Brazilian continental margin remains completely void of studies. This is a particularly relevant sector of the continental margin for reconstructing the strength of the SASM and the South American Convergence Zone (SACZ), the transient convective system that transports Amazon moisture to central and southeastern SA (Figure 2) (Vera et al., 2006).

Within the continent, stalagmite $\delta^{18} \mathrm{O}$ records from caves in southeastern SA related negative $\delta^{18} \mathrm{O}$ excursions with intensification in the SASM during Heinrich events (Cruz et al., 2006; Stríkis et al., 2015; Wang et al., 2007). 
58 climate change events impacted central eastern South American climate during Termination

59 1. We combine a detailed stalagmite $\delta^{18} \mathrm{O}$ record from central South America with XRF-

60 scanner and EDP-XRF data from a marine sediment core collected from the adjacent

61 western tropical South Atlantic, as well as with the output from a transient forcing model

62 run to reconstruct continental climate conditions. Our records show that abrupt temperature

63 oscillations in Greenland during the Bølling-Allerød (BA) (Rasmussen et al., 2006)

64 happened synchronously to changes in hydrological patterns in central South America.

65 Moreover, the Bølling and Allerød events were related to decreased intensity of the SASM,

66 separated by a brief wetter excursion, recognized as equivalent to the Older Dryas.

\section{2. Regional setting}

In this paper we present a record of major elements from marine sediments from the western South Atlantic and a speleothem stable isotope record from eastern South America. The marine site is located $105 \mathrm{~km}$ from the modern Brazilian coastline and $110 \mathrm{~km}$ of the current mouth of the Doce River, while the stalagmites used here were collected at Lapa Sem Fim Cave (Figure 1).

Terrigenous sediment at the marine core site (Figure 1) have been directly delivered by the Doce River (Tintelnot, 1995; Tintelnot et al., 1998) during Late Pleistocene, when the river's mouth was located beyond the shelf break, locally between 60 and $70 \mathrm{~m}$ water depth (Bastos et al., 2015). Nowadays, most of the terrigenous material from the Doce

77 River is deposited at the continental shelf, but under pleistocenic low sea-level conditions, the terrigenous sediment was transported to the study site via one of the presently-drowned channels of the Doce River Canyon System (Figure 1 inset) (Brush et al., 2004; Maia, 80 2013; Schreiner et al., 2009). Connections between the modern Doce River and the several

81 incised valleys which constitute the Doce River Canyon System have been previously 82 suggested in the scientific literature (Alves, 1999; A. M. C. França, 1979; M. C. França et 83 al., 2015; Maia, 2013), and at the mid-continental slope of the Abrolhos Bank and Doce 84 River shelf Massé et al. (1996) and Tintelnot (1995) registered high kaolinite contents, 85 connected with the eastern and southeastern Brazilian rivers' mineralogical signature.

86 The Doce River Basin (Figure 1) is an important medium sized drainage basin in 
87 eastern Brazilian coastal zone (de Oliveira et al., 2012; Marques et al., 2004) with area of $88 \quad 86.715 \mathrm{~km}^{2}$ (http://www.cbhdoce.org.br/; Souza and Knoppers, 2003) constituting the 89 second largest drainage basin in eastern Brazil. The Doce River originates in the 90 mountainous hinterland, over 1300m of altitude (i.e., Serra da Mantiqueira and Serra do 91 Espinhaço) and throughout its $850 \mathrm{~km}$ course crosses the crystalline Precambrian basement, 92 covered by a thick weathered mantle, and the Tertiary coastal iron-rich sediments of the 93 Barreiras-Formation (Carmo and Vasconcelos, 2004; Gunnell, 1998).

94 The Doce River drainage basin is under a hot and humid tropical climate with 95 marked rainy summer and dry fall-winter seasons (Cwb, Cwa and Aw Köppen-Geiger 96 climate types, Peel et al., 2007). This seasonality is due to the SASM and SACZ activity, 97 and average precipitation in the basin is $1400 \mathrm{~mm} / \mathrm{a}$ with at least $80 \%$ falling during the 98 rainy season (October to March). Exceptionally, in areas close to the coast, rains are 99 distributed throughout the year, with austral winter rainfall brought by extratropical 100 cyclones (Garreaud et al., 2009). The Doce River discharge follows the rainfall pattern and 101 is strongly seasonal varying from $500 \mathrm{~m}^{3} / \mathrm{s}$, from May to October, to $1300 \mathrm{~m}^{3} / \mathrm{s}$, from

102 November to April (source: www2.ana.gov.br, runoff measurements from the Colatina 103 Water Station, located $90 \mathrm{~km}$ from the river mouth).

104 The outer shelf and the upper $600 \mathrm{~m}$ of the water column over the continental slope 105 are occupied by the Brazil Current (BC) (Figure 1). Starting around $10^{\circ} \mathrm{S}$, the BC originates 106 from the South Equatorial Current as a relatively weak western boundary current (R. G. 107 Peterson and Stramma, 1991; Stramma and England, 1999) and transports Tropical Surface 108 Water (TSW) and South Atlantic Central Water (SACW) southwards (da Silveira et al., 109 2000; Stramma and England, 1999). 


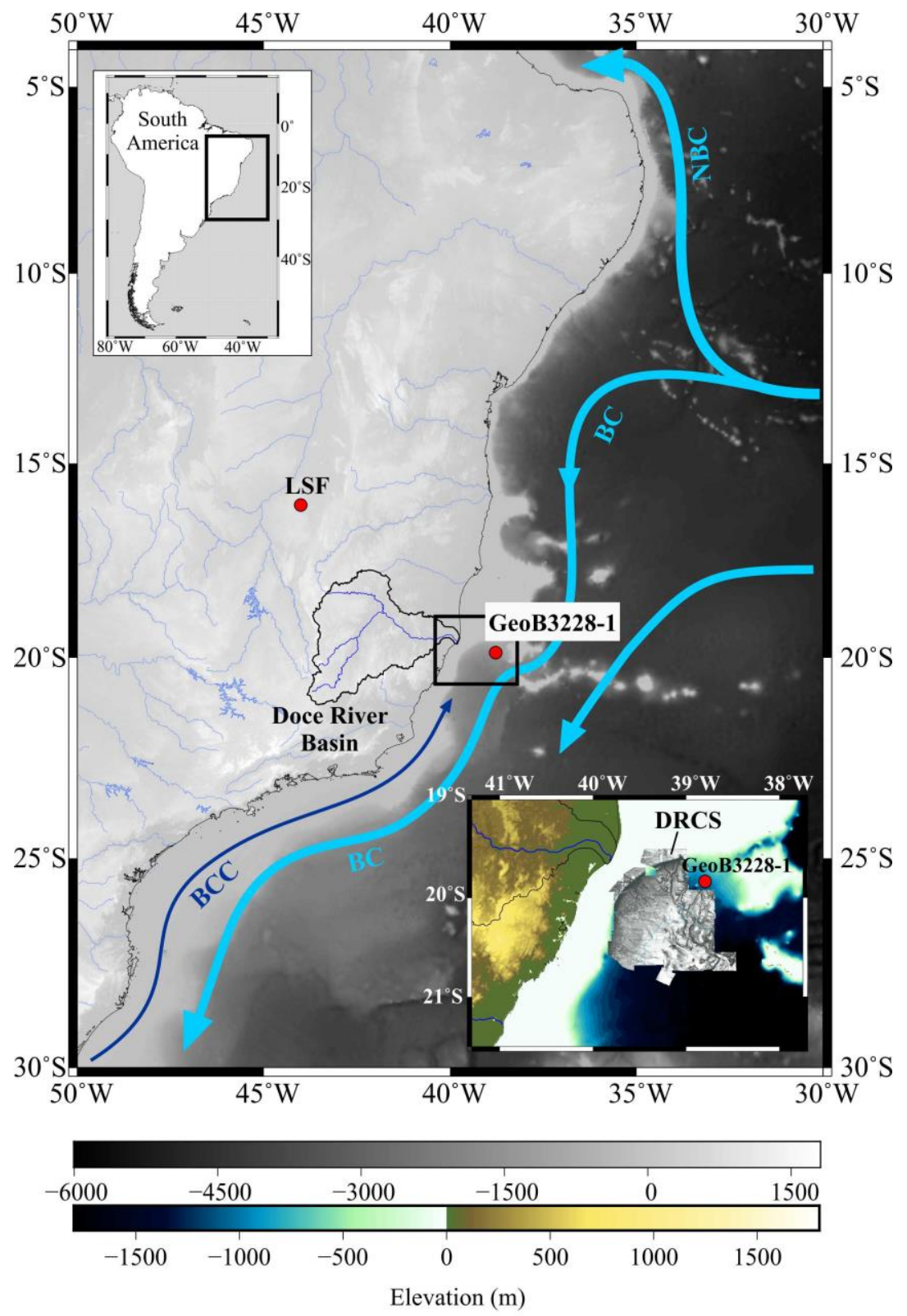

Figure 1: Location of the geological archives investigated in this study (i.e., GeoB3228-1 and Lapa Sem Fim Cave, LSF) and of the Doce River basin in central eastern South America. Lower inset details the location of GeoB3228-1 and the Doce River Canyon System (DRCS, seafloor geomorphology digital model extracted from Schreiner et al., 2009). Surface currents are shown schematically by their acronyms: BC - Brazil Current, BCC - Brazilian Coastal Current, and NBC - North Brazil Current. Figure prepared using topography and bathymetry data from GEBCO14 (www.gebco.net). Doce River basin contour provided by the Brazilian Geological Service (CPRM, http://geobank.cprm.gov.br/). 
113 The interaction of the BC, the morphological barrier of the broad and shallow 114 Abrolhos Bank and the Vitória-Trindade Ridge characterize the surface hydrography in the 115 study area. (Summerhayes et al., 1976) showed that surface temperatures and productivity 116 on the shelf edge are affected by upwelling of SACW during austral summer. Further on, 117 data from surface drifters revealed the unexpected oceanographic complexity of the region, 118 affected by the temporal occurrence and migration of the Vitória Eddy (Schmid et al., 119 1995). Consequently, the Doce River Shelf presents special conditions, where local land 120 input and upwelling of relatively nutrient-rich SACW at the shelf edge are significant 121 factors influencing the local sedimentation and primary production (Ekau and Knoppers, 122 1996; Knoppers et al., 1999; Summerhayes et al., 1976).

123 Between 600 and 1200m, the Intermediate Western Boundary Current transports 124 Antarctic Intermediate Water (AAIW) and the underlying Upper Circumpolar Deep Water 125 (UCDW) equatorwards (da Silveira et al., 2004; Schmid et al., 1995).

126 Lapa Sem Fim Cave (Figure 1) developed in low metamorphic grade limestones of 127 the Bambuí Group (de Almeida et al., 1976), close to center of the modern NW-SE axis of 128 the SACZ (Carvalho et al., 2004) (Figure 2), where precipitation occurs almost exclusively 129 during the active phase of the SASM (e.g., (Vera et al., 2006).

130 The modern climate outside of the cave is tropical semihumid (Aw, Köppen-Geiger 131 climate type, Peel et al., 2007) with mean annual precipitation around $950 \mathrm{~mm}$ 132 (http://www2.ana.gov.br) and rainfall concentrated in the austral summer (90\% of total 133 rainfall amount is recorded from October to March). Once the monsoon season ends, 134 rainfall virtually ceases.

135 The SASM starts in October, has its most active phase between December and 136 February, and demise in April (e.g.,(Marengo et al., 2001; Raia and Cavalcanti, 2008). 137 SASM intensity is mainly influenced by insolation, which is modulated by precession and 138 excentricity in orbital timescales, and ITCZ dynamics in millennial to seasonal timescales. 139 Higher (lower) insolation over the Southern Hemisphere (SH) strengthens (weakens) the 140 monsoon system by increasing (decreasing) the land-sea thermal gradients, and ITCZ 141 positioning is linked to moisture availability to SASM. Nowadays the Atlantic section of 142 ITCZ migrates seasonally reaching its northernmost location, $10^{\circ} \mathrm{N}$, in August and 143 southernmost, $1^{\circ} \mathrm{S}$, in March (mean latitudes at longitude $30^{\circ} \mathrm{W}$, (Nobre and Shukla, 1996), 
144 Nevertheless, it has been suggested that during abrupt cooling events in the Northern

145 Hemisphere it migrated further southward of the Equator, with increased moisture influx to 146 SASM related to southward shifts on ITCZ (Deplazes et al., 2013; L. C. Peterson et al., 147 2000; Stríkis et al., 2015).

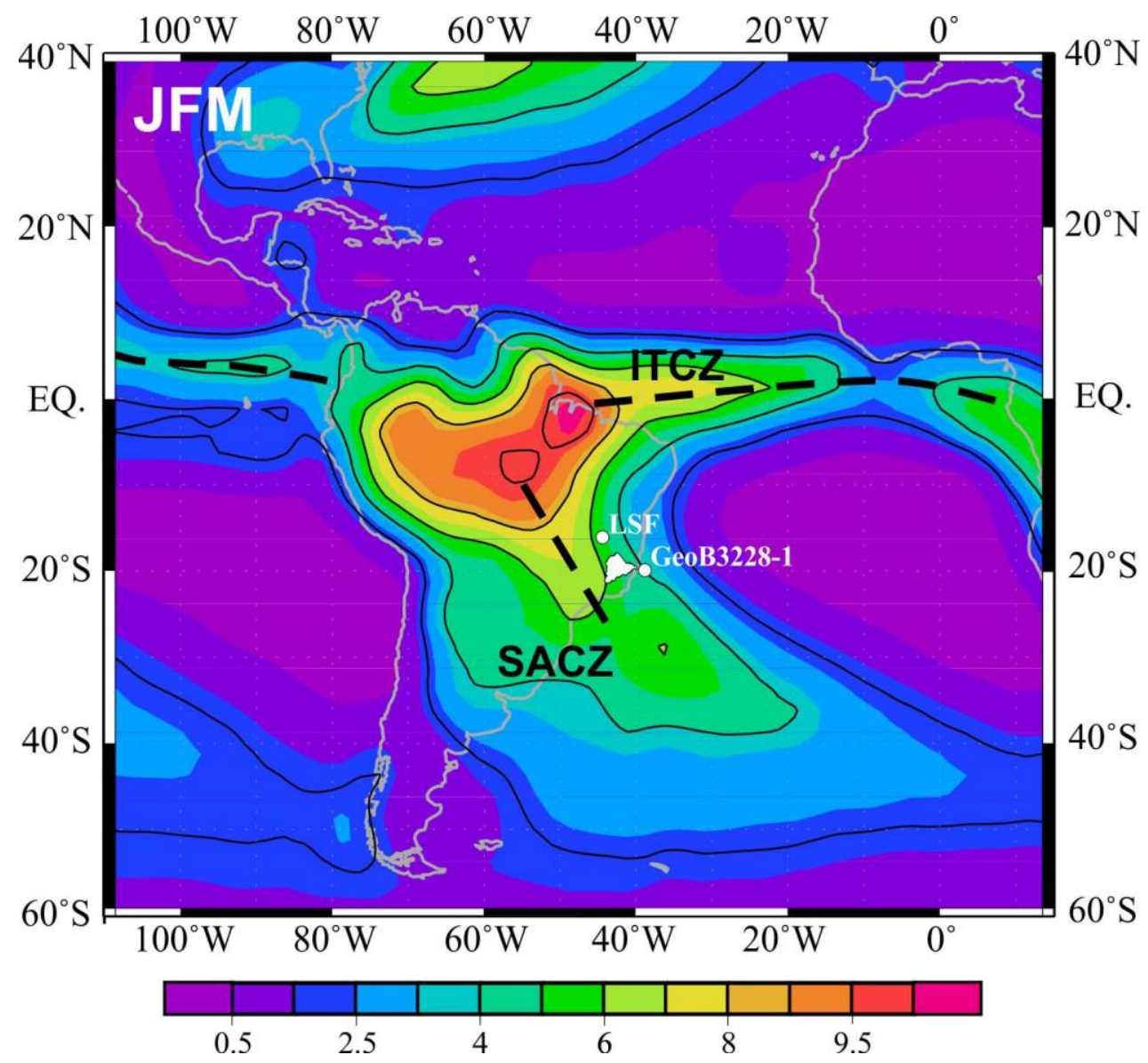

Figure 2: Monthly long term mean precipitation (Xie and Arkin, 1997) during the austral summer (January, February and March; JFM). The Doce River basin is marked in white. Intertropical Convergence Zone (ITCZ) and South Atlantic Convergence Zone (SACZ) are marked in black. Lapa Sem Fim Cave is represented by its acronym LSF.

The SASM pathway to central and southeastern SA follows the SACZ NW-SE axis

149 (Figure 2). The latter is defined as a transient convective system characterized by a 150 nebulosity band formed by transport of Amazon moisture via low level jets to central and 151 southeastern South America (SA) (Vera et al., 2006). SACZ is evident year round but more 152 intense during austral summer, when it is connected with the area of convection over the 153 central part of the continent, and produces episodes of intense rainfall over much of its 154 NW-SE axis (Figure 2) (Liebmann et al., 1999). 


\section{3. Materials and methods}

\subsection{Materials}

The investigated marine gravity core GeoB3228-1 (1945’36” S, 3845’36” W, 1095 mbsl, $567 \mathrm{~cm}$ total length) was retrieved from the Brazilian continental slope during RV Victor Hensen cruise JOPS II, leg 8 (Pätzold et al., 1996) (Figure 1). One-meter-long sections of core GeoB3228-1 were longitudinally split and described, and then stored at $4{ }^{\circ} \mathrm{C}$ at the GeoB Core Repository, MARUM-Center for Marine Environmental Sciences, University of Bremen. Visual core inspection revealed that it is composed mostly of olive gray mud with no (visual) evidence of disturbance within the discussed interval $(158 \mathrm{~cm}$ to $308 \mathrm{~cm}$, (Pätzold et al., 1996). Syringe samples $\left(10 \mathrm{~cm}^{3}\right)$ were collected from the working halves at specific depths for AMS ${ }^{14} \mathrm{C}$ and EDP-XRF analyses.

The stalagmites used in this study, namely LSF15, LSF16 and LSF03, were collected from Lapa Sem Fim Cave (16 $08^{\prime} 52^{\prime}$ 'S , 44 $\left.36^{\circ} 38^{\prime \prime} \mathrm{W}\right)$, located in central-eastern Brazil. The stalagmites were then cut along their growth axis and stored in the Laboratory of Karstic Systems, Geoscience Institute, University of São Paulo. Visual inspection revealed that all three stalagmites are composed of clear and milky white calcite with visible growth layers. Carbonate sampling for isotopic analysis was done with a Sherline 5400 microsampler coupled with a digital ruler, allowing up to $0.4 \mathrm{~mm}$ resolution.

\subsection{Age models}

The age model of marine sediment core GeoB3228-1 was established based on five AMS ${ }^{14} \mathrm{C}$ analyses spaced between 22 and $50 \mathrm{~cm}$ from each other (Table 1). The sample's preparation was executed in the Paleoceanography and Paleoclimatology Laboratory $\left(\mathrm{P}^{2} \mathrm{~L}\right)$ at the School of Arts, Sciences and Humanities of the University of São Paulo, Brazil, and consisted in drying the marine sediment $\left(50^{\circ} \mathrm{C}\right.$ maximum oven temperature), soaking in a beaker with water overnight, wet sieving over $>125 \mu \mathrm{m}$ and $>63 \mu \mathrm{m}$ combined meshes, rinsing both fractions with Milli-Q water and final drying $\left(50^{\circ} \mathrm{C}\right.$ maximum oven temperature) of the residues. After these steps, both fractions $(>125 \mu \mathrm{m}$ and between 125 $\mu \mathrm{m}$ and $63 \mu \mathrm{m})$ were stored in glass vials and labeled. For each sample, $10 \mathrm{mg}$ of tests of planktic foraminifera Globigerinoides ruber and Globigerinoides sacculifer were selected 
184 for $\mathrm{AMS}{ }^{14} \mathrm{C}$ dating from the $>125 \mu \mathrm{m}$ fraction under a binocular microscope. For the 185 sample located at $308 \mathrm{~cm}$ core depth tests of these species did not amount to $10 \mathrm{mg}$ and the 186 required mass was completed with tests from other shallow-dwelling planktic foraminifera 187 available.

188 Radiocarbon analyses were performed at the Beta Analytic Laboratory, Miami, 189 USA or at Poznan Radiocarbon Laboratory, Poznan, Poland. Raw radiocarbon ages were 190 calibrated for the reservoir effect (Bard, 1988; Franke et al., 2008) and for variations on the 191 original ${ }^{14} \mathrm{C}$ concentration in the atmosphere (Reimer et al., 2013) using the online software 192 Calib 7.0.2 (Stuiver and Reimer, 1993) and the Marine13 calibration curve (Reimer et al., 193 2013). All ages are indicated in calibrated years before present (cal kyr BP, here shortened 194 as ka, where present is 2000 A.D.). The age model is based on linear interpolation between 195 calibrated radiocarbon ages (i.e., interpolated from the $2 \sigma$ ranges) for the entire record.

196 For the age model of the Lapa Sem Fim isotopic record, between 100 and $120 \mathrm{mg}$ of 197 speleothem carbonate (depending on U concentration) have been dated by U-Th method 198 using inductively coupled plasma $\square$ mass spectrometry technique at the University of 199 Minnesota, USA, following the procedures described by (Shen et al., 2002). All of the total 20026 datings yield errors < $1 \%$ (Table 1), and of these, 14 had already been published by 201 (Stríkis et al., 2015). The age model was linearly interpolated between U-Th ages for the 202 entire record.

\section{$3.3 \mathrm{Ti} / \mathrm{Ca}$ and $\mathrm{Fe} / \mathrm{Ca}$ in bulk sediments of GeoB3228-1}

$\mathrm{Ti}, \mathrm{Fe}$ and $\mathrm{Ca}$ counts were determined at $5 \mathrm{~mm}$ intervals with 20 seconds of irradiation time directly over the pristine archive halves of the core, using a X-ray fluorescence (XRF) Core Scanner II (AVAATECH Serial No. 2, 10kV, and $0.35 \mathrm{~mA}$ ) at the 207 MARUM - Center for Marine Environmental Sciences, University of Bremen, Germany. 208 Prior and after daily analysis, the instrument was calibrated against a set of pressed powder 209 standards (Jansen et al., 1998). Acquired XRF spectra were processed with the WinAxil 210 and WinBatch software packages. The resulting data were expressed as element intensities 211 in counts per second.

212 Subsequently, 10 discrete samples taken every $17 \mathrm{~cm}$, on average, were freeze213 dried, powdered and homogenized with an agate mortar, and had $\mathrm{Ti}$, $\mathrm{Fe}$ and $\mathrm{Ca}$ 
214 concentrations measured on an energy dispersive polarization X-ray fluorescence (EDP-

$215 \mathrm{XRF}$ ) spectrometer (Panalytical Epsilon 3X). We assessed the analytical quality of the

216 measurements by repeated analyzes of several different certified standard reference

217 materials (e.g. MAG-1; Govindaraju et al., 1994). The measured values were within $1 \%$ of

218 accepted values. The standard deviation of replicated sediment samples was less than $2 \%$.

219 Elements concentrations are expressed in grams per kilogram of dry sediment.

220 The EDP-XRF absolute concentrations were used to calibrate the scanner XRF

221 intensities into calibrated proportions using the regression method described by (Weltje and

222 Tjallingii, 2008). The calibrated curve was then also expressed in grams per kilogram of

223 dry sediment.

\subsection{Oxygen isotopes from Lapa Sem Fim stalagmites}

$225 \quad$ Calcite powder $(\sim 200 \mu \mathrm{m})$ was analyzed with an on-line, automated carbonate 226 preparation system (Finnigan Gas Bench) linked to a Finnigan Delta Plus Advantage mass

227 spectrometer at the Laboratory of Stable Isotopes, University of São Paulo, Brazil. The 228 produced oxygen isotope ratios were corrected using a linear regression curve constructed 229 using analysis results of four different standards: IAEA-CO-8, NBS18, NBS19 and REI, 230 the in house standard. REI and samples were analyzed sequentially on a 1 to 6 ratio. The 231 analytic precision of oxygen isotopic ratios is $\pm 0.1 \%$ and values are reported as $\delta^{18} \mathrm{O}$ 232 relative to the Vienna Peedee Belemnite standard. For clarity, on the comparison with $233 \mathrm{Ti} / \mathrm{Ca}$ ratios, we interpolated the original data for every $65 \mathrm{yrs}$ (the lowest sampling 234 resolution throughout the three stalagmites) using the integrated interpolation function of 235 software AnalySeries version 2.0.8 (Paillard et al., 2011). Since LSF16 and LSF15 are 236 joined at a sensitive period for our discussion, we show their overlapping signal between 15 237 and $14.5 \mathrm{ka}$. LSF16 and LSF03 were joined using their signals overlap as tie point, at 17.33 238 ka. 


\section{Results}

\subsection{Age models}

Gravity core GeoB3228-1 age model (Figure 3a) show an apparently continuous

242 sedimentation from $12.30 \mathrm{ka}$ downwards. The sedimentation rates are high, 35 and 20

$243 \mathrm{~cm} / \mathrm{kyr}$, between the beginning of the record $(23 \mathrm{ka})$ and $18.35 \mathrm{ka}$ and lower $(\sim 8 \mathrm{~cm} / \mathrm{kyr})$,

244 but stable, between $18.35 \mathrm{ka}$ and the end of the record at $12.30 \mathrm{ka}$.

245 Depths and U-Th datings, an important contribution to this work is the robust

246 chronological control of our Lapa Sem Fim (LSF) speleothem record, from the stalagmites

247 LSF15, LSF16 and LSF03 were combined in a composite record (Figure 3b). The LSF03

248 age model section was established with 7 ages and covers the interval from 22.86 until

$24917.34 \mathrm{ka}$. The LSF16 age model section was produced with 10 ages spanning from $17.29 \mathrm{ka}$

250 until $14.53 \mathrm{ka}$. The LSF15 age model section is based on 8 ages straddling from $15.21 \mathrm{ka}$

251 until $12.13 \mathrm{ka}$. The LSF composite growth rate averaged $10.58 \mathrm{~cm} / \mathrm{kyr}$ and varied from 1.54

$252 \mathrm{~cm} / \mathrm{kyr}$ between $20.46 \mathrm{ka}$ and $19.35 \mathrm{ka}$ within LSF03 to $77 \mathrm{~cm} / \mathrm{kyr}$ between $14.75 \mathrm{ka}$ and

$25314.53 \mathrm{ka}$ within LSF16. At the same period, LSF15 presented an average of $7.7 \mathrm{~cm} / \mathrm{kyr}$.

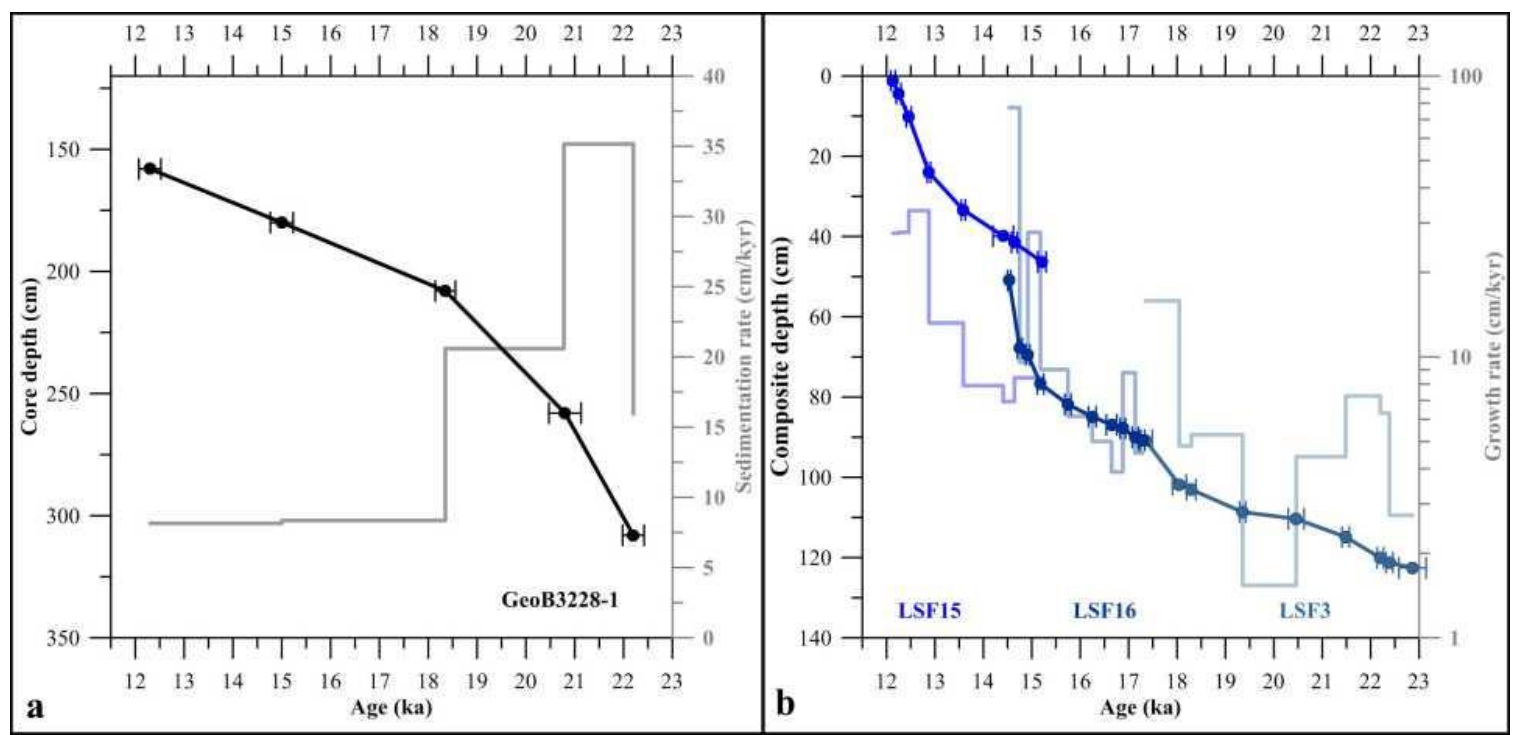

Figure 3: Age models of marine sediment core GeoB3228-1 (a) and Lapa Sem Fim Cave composite record (b) with respective sedimentation and growth rates, respectively. Age models are represented in darker colors and sedimentation and growth rates in correspondent lighter colors. 
Table 1

Accelerator mass spectrometer radiocarbon dates and calibrated ages used to construct the age model of core GeoB3228-1

\begin{tabular}{|c|c|c|c|c|c|c|}
\hline $\begin{array}{l}\text { Core depth } \\
(\mathrm{cm})\end{array}$ & Lab ID* & Species & $\begin{array}{l}\text { Radiocarbon age +/- } \\
1 \sigma \text { error (a BP) }\end{array}$ & $\begin{array}{l}2 \sigma \text { calibrated age } \\
\text { range (cal a BP) }\end{array}$ & $\begin{array}{l}\text { Calibrated age, interpolated } \\
\text { from } 2 \sigma \text { range }(\mathrm{ka})\end{array}$ & Source \\
\hline \multicolumn{7}{|l|}{ GeoB3228-1 } \\
\hline 158 & Beta-361841 & $\begin{array}{l}\text { G. ruber / G. } \\
\text { sacculifer }\end{array}$ & $10770+/-50$ & $12016-12468$ & 12.29 & This study \\
\hline 180 & Beta-409779 & G. ruber & $13020+/-50$ & $14724-15191$ & 15.01 & This study \\
\hline 208 & Beta-361842 & $\begin{array}{l}\text { G. ruber, G. } \\
\text { sacculifer }\end{array}$ & $15480+/-60$ & $18101-18512$ & 18.36 & This study \\
\hline 258 & Poz-45336 & $\begin{array}{l}\text { G. ruber, } G \text {. } \\
\text { sacculifer }\end{array}$ & $17580+/-120$ & $20064-21060$ & 20.61 & This study \\
\hline 308 & Beta-385301 & $\begin{array}{c}\text { Planktic } \\
\text { foraminifera }\end{array}$ & $18710+/-60$ & $21938-22377$ & 22.21 & This study \\
\hline
\end{tabular}

* Beta: BETA Analytic Laboratory, Miami, USA; Poz: Poznan Radiocarbon Laboratory, Poznan, Poland.

\section{Table 2}

U-Th ages used to construct the age models of Lapa Sem Fim Cave stalagmites

\begin{tabular}{|c|c|c|c|c|}
\hline $\begin{array}{l}\text { Speleothem } \\
\text { depth }(\mathrm{cm})\end{array}$ & Lab ID & $\begin{array}{c}\text { Corrected 230Th Age } \\
\text { (ka) }\end{array}$ & Error (a BP) & Source \\
\hline \multicolumn{5}{|l|}{$L S F 15$} \\
\hline 1.2 & LSF15-1 & 12.134 & \pm 47 & This study \\
\hline 4.4 & LSF15-3 & 12.250 & \pm 49 & This study \\
\hline 10.2 & LSF15-4 & 12.459 & \pm 51 & This study \\
\hline 24 & LSF15-6 & 12.875 & \pm 35 & This study \\
\hline 33.4 & LSF15-8 & 13.587 & \pm 42 & This study \\
\hline 41.5 & LSF15-10 & 14.641 & \pm 59 & This study \\
\hline 46.3 & LSF15-11 & 15.211 & \pm 84 & This study \\
\hline \multicolumn{5}{|l|}{$L S F 16$} \\
\hline 4.65 & LSF16-2 & 14.533 & \pm 33 & Stríkis et al., 2015 \\
\hline 21.55 & LSF16-3 & 14.752 & \pm 50 & Stríkis et al., 2015 \\
\hline 23.15 & LSF16-4 & 14.919 & \pm 41 & Stríkis et al., 2015 \\
\hline 30.42 & LSF16-5 & 15.181 & \pm 68 & Stríkis et al., 2015 \\
\hline 35.53 & LSF16-7 & 15.748 & \pm 64 & Stríkis et al., 2015 \\
\hline 38.61 & LSF16-8 & 16.249 & \pm 79 & Stríkis et al., 2015 \\
\hline 40.61 & LSF16-9 & 16.649 & \pm 108 & Stríkis et al., 2015 \\
\hline 41.51 & LSF16-10 & 16.880 & \pm 56 & Stríkis et al., 2015 \\
\hline 43.76 & LSF16-11 & 17.136 & \pm 63 & Stríkis et al., 2015 \\
\hline 44.46 & LSF16-12 & 17.290 & \pm 42 & Stríkis et al., 2015 \\
\hline \multicolumn{5}{|l|}{$L S F 03$} \\
\hline 0 & LSF3-A & 17.346 & \pm 141 & Stríkis et al., 2015 \\
\hline 11.1 & LSF3-B & 18.047 & \pm 141 & Stríkis et al., 2015 \\
\hline 12.3 & LSF3-128 & 18.296 & \pm 92 & Stríkis et al., 2015 \\
\hline 17.9 & LSF3-188 & 19.356 & \pm 64 & Stríkis et al., 2015 \\
\hline 19.6 & LSF3-C & 20.461 & \pm 164 & This study \\
\hline 24.1 & LSF3-253-REP & 21.482 & \pm 76 & This study \\
\hline 29.3 & LSF3-306 & 22.198 & \pm 66 & This study \\
\hline 30.5 & LSF3-316 & 22.388 & \pm 71 & This study \\
\hline 31.8 & LSF3-D & 22.864 & \pm 281 & This study \\
\hline
\end{tabular}


Our $5 \mathrm{~mm}$ step XRF measurements yielded 335 measurements in total with temporal resolution between 14 and $61 \mathrm{yrs}$ (33 yrs on average). Also on average the proportion by weight between Fe : Ti : Ca on GeoB3228-1 was $0.63: 0.07: 1$.

EDP-XRF calibrated $\ln (\mathrm{Ti} / \mathrm{Ca})$ and $\ln (\mathrm{Fe} / \mathrm{Ca})$ records show virtually identical 263 curves for the whole record (23.00 to $12.30 \mathrm{ka}$ ) (Figure 3). Elemental ratios remain 264 relatively high between the beginning of the record at $23.00 \mathrm{ka}$ and $15.93 \mathrm{ka}$, forming a 265 plateau interrupted only by 3 excursions to lower values ranging from 400 to $800 \mathrm{yr}$ in 266 duration (centered at 20.08, 18.37 and $16.38 \mathrm{ka}$ ). After $15.93 \mathrm{ka}, \ln (\mathrm{Fe} / \mathrm{Ca})$ and $\ln (\mathrm{Ti} / \mathrm{Ca})$ 267 begin a steady decrease, briefly interrupted at $15.67 \mathrm{ka}$, until $15.23 \mathrm{ka}$ after which they 268 show a slight increase. At $14.92 \mathrm{ka}, \ln (\mathrm{Fe} / \mathrm{Ca})$ and $\ln (\mathrm{Ti} / \mathrm{Ca})$ sharply resume the decreasing 269 trend until $13.69 \mathrm{ka}$, when they reach minimum values. From $13.69 \mathrm{ka}$ onwards, elemental 270 ratios increase towards plateau values until the end of the record. Since $\ln (\mathrm{Fe} / \mathrm{Ca})$ and $271 \ln (\mathrm{Ti} / \mathrm{Ca})$ present virtually identical records, we decide to use only $\ln (\mathrm{Ti} / \mathrm{Ca})$ for the 272 discussion.

\subsection{Oxygen isotopes from Lapa Sem Fim stalagmites}

Our isotope record is composed of $840 \delta^{18} \mathrm{O}$ values, yielding a temporal resolution between 3 and 65 yrs (15 yrs on average). The $\delta^{18} \mathrm{O}$ signal averaged $-6 \%$ o through the whole studied period (23 to $12.30 \mathrm{ka}$ ) and oscillated with amplitude of 5.9\%o. It is worthy of note that the $\delta^{18} \mathrm{O}$ data from LSF16 and part of LSF03 (up until $19.35 \mathrm{ka}$ ) was originally published by (Stríkis et al., 2015).

The LSF composite $\delta^{18} \mathrm{O}$ begins at 22.86 shows $-6 \%$ at the base of the record, 280 trending toward less negative values until $21.35 \mathrm{ka}$, after that values stabilize around $-5 \%$ 281 for $1.1 \mathrm{kyr}$ and sharply increase at $20.22 \mathrm{ka}$ and remain around $-4 \%$ for $\sim 400$ years . At $28219.83 \mathrm{ka} \delta^{18} \mathrm{O}$ values decrease to $-6 \%$ and oscillate around that value for 700 years. At $28319.14 \mathrm{ka}$ isotopic values increase $1 \%$ on a less negative excursion that lasted 800 years 284 until $18.29 \mathrm{ka}$, when $\delta^{18} \mathrm{O}$ values gradually resume decreasing. From $18.11 \mathrm{ka}$ onwards the 285 record is composed by two consecutive double-plunged shapes. The oldest, between 18.11 to $14.7 \mathrm{ka}$, characterized by isotopic values oscillating from $-8.6 \%$ and $-6 \%$ is interrupted 
287 by a lasting less negative excursion centered at $16.38 \mathrm{ka}$ (when values reached $\sim-6.5 \%$ ) 288 and a briefer one centered at 17.19 ka (Stríkis et al., 2015). The youngest double-plunged 289 structure on the isotopic record ranged from $14.7 \mathrm{ka}$ and $12.58 \mathrm{ka}$ with values oscillating 290 from $-6.8 \%$ and $-2.8 \%$. The latter was interrupted by a more negative excursion around $29114.00 \mathrm{ka}$.

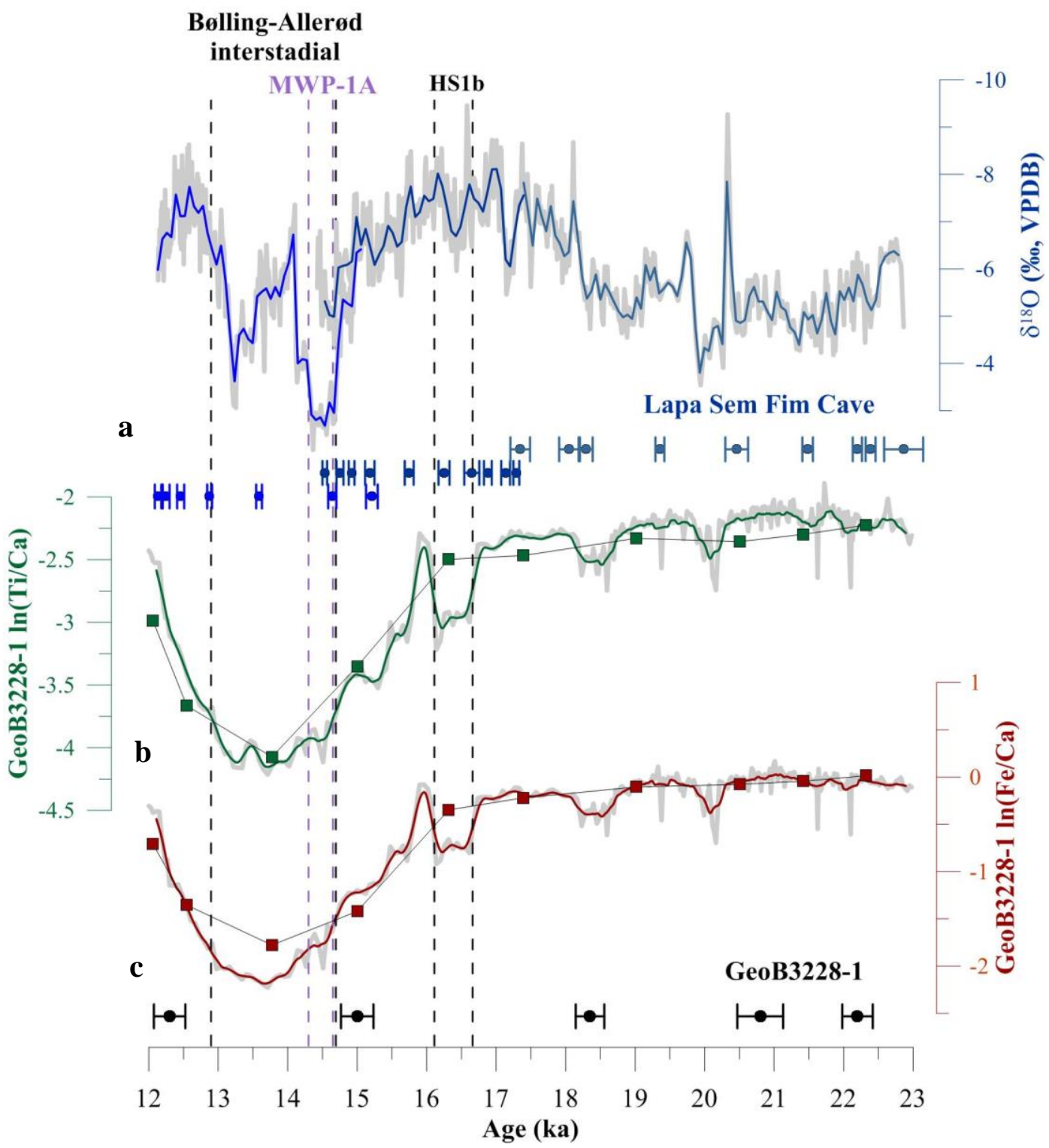

Figure 4: Lapa Sem Fim Cave $\delta^{18} \mathrm{O}$ composite record (a), and GeoB3228-1 Ti/Ca (b) and $\mathrm{Fe} / \mathrm{Ca}$ (c) records. U-Th ages with respective error bars are represented in blue, ${ }^{14} \mathrm{C}$ ages and their respective error bars $(2 \sigma)$ are represented in black. The vertical dashed lines mark: Heinrich Stadial 1b (HS1b, Stríkis et al., 2015), Melt Water Pulse 1A (MWP1A, Deschamps et al., 2012) and the Bølling-Allerød interstadial (Rasmussen et al., 2006, 2014 ). 


\section{Discussion}

\subsection{Ti/Ca and Fe/Ca in bulk sediments of GeoB3228-1}

$\mathrm{Fe}$ and $\mathrm{Ti}$ within marine sediment cores can be used as tracers of the siliciclastic components of terrestrial sediments, and vary proportionally to the terrigenous fraction, whereas $\mathrm{Ca}$ is largely derived from biogenic $\mathrm{CaCO}_{3}$ shell material (i.e., mostly pteropods, foraminifera, and calcareous nannoplankton) (Govin et al., 2012). Elemental ratios including $\mathrm{Ca}$ (e.g., $\mathrm{Fe} / \mathrm{Ca}$ ) are sensitive to dilution effects (i.e., enhanced biological productivity, carbonate dissolution), which can affect reconstructions of terrestrial climate. Nevertheless, in our record, post depositional carbonate dissolution and/or overgrowth were not observed and could be ruled out, validating the use of $\mathrm{Ti} / \mathrm{Ca}$ and $\mathrm{Fe} / \mathrm{Ca}$ to discuss marine versus terrigenous input as described below.

We assume that $\mathrm{Ca}$ fluxes remained relatively constant throughout the recorded period. Only a few studies investigated changes in paleoproductivity in the oligothrophic western South Atlantic Ocean (i.e., Mahiques et al., 2007; Nagai et al., 2010; Toledo, 2008; Toledo et al., 2007). Toledo (2008) developed their work in an area affected by the Cabo Frio upwelling system (Mahiques et al., 2005) and the changes in productivity were mainly attributed to increased/decreased upwelling, which do not necessarily correspond to oceanic conditions in our study area. Mahiques et al. (2007) and Nagai et al. (2010) found increased productivity during the Last Glacial Maximum (LGM, 23 to 19 ka, Mix et al., 2001) and

$313 \mathrm{Fe} / \mathrm{Ca}$ and $\mathrm{Ti} / \mathrm{Ca} \log$ ratios remained stable, which led us to assume that possible 314 productivity changes during our our studied time window did not affect our signal.

Sea level rise, however, appears to have modulated our signal. Each of the 316 progressively younger decreases in $\ln (\mathrm{Ti} / \mathrm{Ca}$ ) has a higher amplitude in relationship to the 317 previous one, consistent with progressive distancing of the river mouth from the study site 318 due to sea level rise. Between 23 and $12 \mathrm{ka}$, sea level rose around $65 \mathrm{~m}$ globally (e.g., 319 Lambeck and Chappell, 2001), with the highest sea level change rates occurring during 320 Melt Water Pulse 1A (MWP1A, Deschamps et al., 2012). MWP1A began at $14.65 \mathrm{ka}$ and 321 was synchronous to the onset of the BA. At $\sim 14.7 \mathrm{ka}$, there is indeed a sharp decrease in 322 our Ti/Ca and $\mathrm{Fe} / \mathrm{Ca}$ records (Figure 4). 
Previous works have used $\mathrm{Ti} / \mathrm{Ca}$ and $\mathrm{Fe} / \mathrm{Ca}$ ratios to trace changes in terrigenous 324 input of fluvial origin of South American rivers, particularly offshore the semiarid northeastern Brazil, where repeated authors pointed out increases in the terrigenous input

326 during Heinrich events due to southward shifts of the ITCZ (Arz et al., 1999; 1998;

327 Jaeschke et al., 2007; Jennerjahn et al., 2004; Nace et al., 2014; Zhang et al., 2015).

In comparison to these studies though, we observe a different trend in our data. The noticeable features of our records are the lower terrigenous excursions centered at 20.08, $18.37,16.38,15.23$ and $13.65 \mathrm{ka}$ representing decrease in terrigenous input to the basin, which translate into dry periods in the catchment area and decreased Doce River runoff. Curiously, Ti/Ca and Fe/Ca remained stable even during time windows when we would expect SASM related terrigenous input to increase (e.g., Stríkis et al., 2015). This can be tentatively explained by three hypotheses, explored on subsection 5.3.

The most prominent features observed in our curves is by far the long standing decrease in $\mathrm{Ti} / \mathrm{Ca}$ and $\mathrm{Fe} / \mathrm{Ca}$ between $15.5 \mathrm{ka}$ and $12.5 \mathrm{ka}$, which starts before the BA (at $14.7 \mathrm{ka}$ ) and ends with ratios increasing again almost to plateau values during the Younger Dryas (YD).

\section{2 $\delta^{18} \mathrm{O}$ in stalagmites from Lapa Sem Fim Cave}

Speleothem $\delta^{18} \mathrm{O}$ in tropical and subtropical lowlands is usually interpreted as a

341 precipitation proxy, indicating changes in precipitation source (Cruz et al., 2006; 2005)

342 and/or amount (Bony et al., 2008; Risi et al., 2008). The first imply that moisture becomes

343 progressively impoverished in ${ }^{18} \mathrm{O}$ as further away from its source it travels, and the second

344 describes the negative correlation between monthly rainfall amount and monthly weighted 345 mean $\delta^{18} \mathrm{O}$. Given that in the LSF area $90 \%$ of the annual precipitation is related to SASM 346 activity, negative (positive) anomalies in $\delta^{18} \mathrm{O}$ from LSF stalagmites have been interpreted 347 to reflect increases (decreases) in precipitation, that, in turn, are related with higher (lower) 348 intensity of the SASM (Stríkis et al., 2015; 2011).

349 Based on this assumption, our $\delta^{18} \mathrm{O}$ signal shows neither too wet nor too dry 350 conditions between 23 and $18.1 \mathrm{ka}$. The most remarkable feature during this period being a 351 drier excursion between 20.64 and $20.13 \mathrm{ka}$ (which is also related with the smallest growth 352 rate in our record, the $1.54 \mathrm{~cm} / \mathrm{kyr}$ between 20.43 and $19.35 \mathrm{ka}$ ). 
354 representing two drier excursions separated by a relatively wet one, correspondent to the 355 Bølling (14.7 - $14.13 \mathrm{ka})$, Older Dryas (14.13-13.86 ka) and Allerød (13.86 - $13.15 \mathrm{ka})$

356 periods, in chronological order (period names according to Mangerud et al., 1974). On 357 LSF15 between 13.15 and $12 \mathrm{ka}, \delta^{18} \mathrm{O}$ are more negative, pointing to SASM intensification 358 right before and during the YD. It is worthy of note that the LSF record presented here is 359 the most detailed record describing precipitation changes within the Bølling-Allerød 360 interstadial in South America.

\subsection{Integrating elemental ratios and stable isotopes}

LSF $\delta^{18} \mathrm{O}$ records 8 excursions toward less negative values that are synchronous to decreases on $\mathrm{Ti} / \mathrm{Ca}$ and $\mathrm{Fe} / \mathrm{Ca}$ from GeoB3228-1 (with the exception of one, at $17.20 \mathrm{ka}$ )

364 (Figure 5). This confirms that excursions toward less negative values on our speleothem 365 record are connected with runoff decrease in the Doce River Basin, as shown by the decreases on $\mathrm{Ti} / \mathrm{Ca}$ and $\mathrm{Fe} / \mathrm{Ca}$. Since over $80 \%$ of the rainfall on the Doce River basin and

367 Lapa Sem Fim Cave is brought by SASM, we interpret that during these periods the 368 monsoon intensity was weakened, likely connected with decrease in moisture influx caused 369 by relatively northward positioning of the ITCZ.

370 However, the inverse seems not to be valid, i.e., excursions toward more negative $371 \delta^{18} \mathrm{O}$ values on LSF are not related to increased Ti/Ca and Fe/Ca log ratios on GeoB3228-1. 372 There are two possibly related hypotheses to explain this apparent mismatch, each 373 involving one of our proxies.

374 First, decreases in stable isotopes ratios in speleothems formed under ideal 375 conditions (i.e., calcite crystallization in isotopic equilibrium with drop water isotopic 376 content) are produced by the amount effect (i.e., ${ }^{18} \mathrm{O}$ impoverishment on rainfall moisture 377 linearly correlated with the amount of rainfall (Bony et al., 2008; Risi et al., 2008)) over the 378 karstic system or along the moisture path since its departure from the reservoir, which is 379 primarily the ocean. Hence, calcite isotopic composition is not necessarily only a recorder 380 of precipitation amount over the cave itself, as the moisture can have been depleted 381 progressively and unequally along its pathway from the reservoir. In this scenario, 382 increased precipitation over the Amazon due to southward ITCZ shifts would already 
383 transmit ${ }^{18} \mathrm{O}$-poor moisture to areas under SACZ influence without necessarily increasing 384 rainfall amount over the cave.

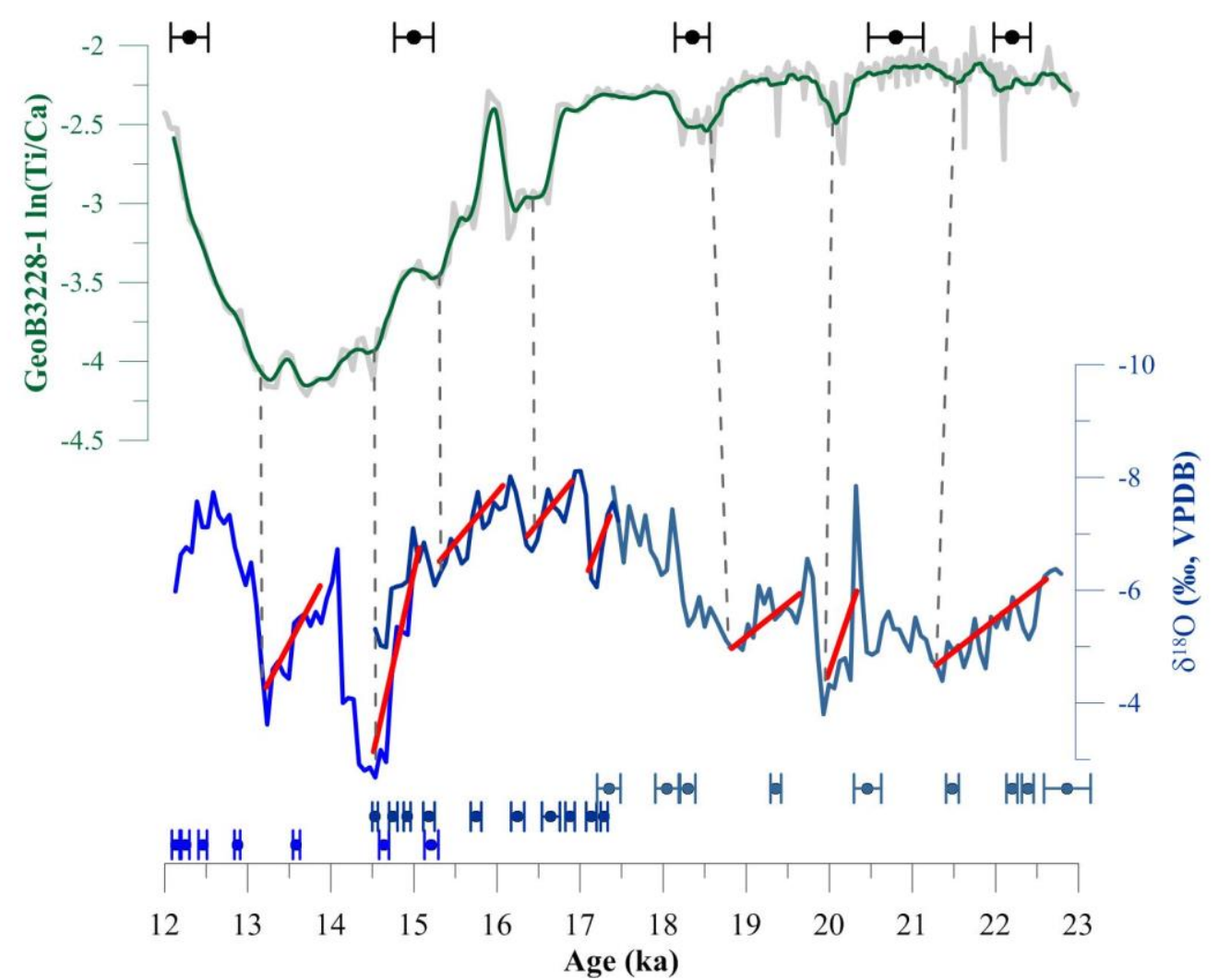

Figure 5: Detailed comparison between GeoB3228-1 $\ln (\mathrm{Ti} / \mathrm{Ca})$ and Lapa Sem Fim Cave $\delta^{18} \mathrm{O}$. Blue circles represent U-Th ages and correspondent error bars. Black circles represent ${ }^{14} \mathrm{C}$ datings with correspondent $2 \sigma$ uncertainty. Grey dashed lines connect lower $\ln (\mathrm{Ti} / \mathrm{Ca})$ values with less negative $\delta^{18} \mathrm{O}$ excursions (red lines).

Second, different weathering patterns and sediment transport between densely vegetated tropical eastern SA and the semiarid areas should also be considered. As mentioned above, previous studies that assessed shifts in precipitation and the related changes in $\mathrm{Ti} / \mathrm{Ca}$ and $\mathrm{Fe} / \mathrm{Ca}$ were carried out off northeastern Brazil (Arz et al., 1998;

390 Jaeschke et al., 2007; Jennerjahn et al., 2004; Nace et al., 2014; Zhang et al., 2015). That 391 area is characterized by semiarid climate (Bsh, Köppen-Geiger climate type, Peel et al., 392 2007) which favor a fast response of the terrigenous input to oceanic basins for several 393 reasons. As the countryside is usually hot and dry, the landscape is dominated by relatively 394 sparse savanna vegetation (Cole, 1960; Machado et al., 1997) and shallow rock-soil 395 interface (Bétard et al., 2007). Under these conditions, abrupt floods or increased rainfall 
396 amount can easily transport weathered material to the ocean, increasing $\mathrm{Ti} / \mathrm{Ca}$ and $\mathrm{Fe} / \mathrm{Ca}$

397 ratios in case of wetter conditions. Inversely, the humid climate of the Doce River Basin

398 favors the development of thick weathering profiles and well developed tropical vegetation.

399 In this scenario, weathering profiles are better fixated and to some extent protected from

400 erosion thus, characterizing a vegetational buffer to terrigenous input to the ocean caused

401 by precipitation increase. The inverse, decrease of rainfall, naturally leads to decreased

402 river runoff and terrigenous material transport, in accordance with both our records (Figure $4035)$.

404 Relying on either one of these hypotheses does not affect our conclusions, that 405 central eastern SA experienced extremely drier than average conditions at specific periods 406 during Termination I and LGM, most prominently during the BA. We suggest that these 407 drier periods were related to weakened intensity of SASM.

\section{$408 \quad 5.4$ The Bølling-Allerød interstadial in South America}

A northward shift of the ITCZ during the BA (see Deplazes et al., 2013) and references therein) would have decreased the moisture influx to the SASM, decreasing also 411 its intensity and, consequently the amount of precipitation in our study area.

412 We further compared our $\mathrm{Ti} / \mathrm{Ca}$ and $\delta^{18} \mathrm{O}$ records with the output of the 413 SYNTRACE run of the CCSM3 fully-coupled climate model with transient forcing for the 414 last deglaciation or Termination I $\left(45^{\circ} \mathrm{W}\right.$ to $37^{\circ} \mathrm{W}, 20^{\circ} \mathrm{S}$ to $13^{\circ} \mathrm{S}$, Liu et al., 2009) (Figure 415 6a). In this simulation, the HS1 increase in precipitation over the region of the Rio Doce 416 Basin was relatively smaller than the abrupt decrease due to the onset of the BA. Also, in 417 agreement with our results, the BA was the driest period within 23 and $12 \mathrm{ka}$. The model, 418 however, does show the earlier transition to drier conditions in the end of HS1 and before 419 the BA, as shown by $\mathrm{Ti} / \mathrm{Ca}$ ratios in our marine sediment core. We assume this happens 420 because the model was elaborated mainly with Northern Hemispheric forcings (Liu et al., 421 2009) that exclude the regional variations which can have caused such earlier SASM 422 intensity decrease in the end of the HS1.

423 The marine sediment cores GeoB3129-1 and GeoB3911-3 (Arz et al., 1999; 424 Jennerjahn et al., 2004; Weldeab et al., 2006) (Figure 6e), were collected off northeastern 425 Brazil, where southward shifts of the ITCZ resulted in increased terrigenous input (Fe/Ca 
426 ratios). Fe/Ca composite from cores GeoB3129-1 and GeoB3911-3 show the same 427 precipitation trend implied by LSF $\delta^{18} \mathrm{O}$ (Figure 6c) and similar to GeoB3228-1 Ti/Ca 428 (Figure 6d) and Fe/Ca ratios. The HS1 structure described by (Stríkis et al., 2015) can also 429 be recognized in the GeoB3129-1 / GeoB3911-3 Fe/Ca composite, showing a prominently 430 wet HS1c, followed by a dry excursion compatible with HS1b, a brief return to wetter 431 conditions in the beginning of the HS1a, followed by a transitional passage to drier 432 conditions that remain during the BA. On both GeoB3228-1 and GeoB3129-1 / GeoB3911$4333 \mathrm{Fe} / \mathrm{Ca}$ composite the beginning of the Bølling period is indistinguishable from the end of 434 HS1a. The Fe/Ca increase (on GeoB3129-1/GeoB3911-3 composite) at 14 ka is relatable 435 with the LSF $\delta^{18} \mathrm{O}$ decrease between Bølling and Allerød periods, possibly explainable by a 436 brief southward shift of the ITCZ during the Older Dryas cold period in the Northern 437 Hemisphere. This southward shift would have briefly intensified SASM, reflecting as more 438 negative $\delta^{18} \mathrm{O}$ values on our Lapa Sem Fim Cave composite and not being recorded in our 439 marine sediment core due to the intrinsic characteristics of $\mathrm{Ti} / \mathrm{Ca}$ and $\mathrm{Fe} / \mathrm{Ca}$ ratios from 440 Doce River basin, already discussed in the previous subsection.

441 On GeoB3228-1 $\mathrm{Ti} / \mathrm{Ca}$ and $\mathrm{Fe} / \mathrm{Ca}$ ratios, the $14.7 \mathrm{ka}$ abrupt decrease in the 442 terrigenous input can be connected to either a rapid decrease in SASM intensity or the fast 443 sea level rise during MWP1A (Deschamps et al., 2012).

444 The comparison between precipitation estimations from SYNTRACE run of the 445 CCSM3 (Liu et al., 2009), Fe/Ca from marine sediment cores GeoB3129-1 and GeoB39114463 (Arz et al., 1999; Jennerjahn et al., 2004; Weldeab et al., 2006) and our coupled 447 GeoB3228-1 Ti/Ca and LSF $\delta^{18} \mathrm{O}$ allow us to confirm decreased SASM intensity in eastern 448 SA during the BA, likely related to northward positiong of ITCZ and consequent reduced 449 moisture influx to SASM. 

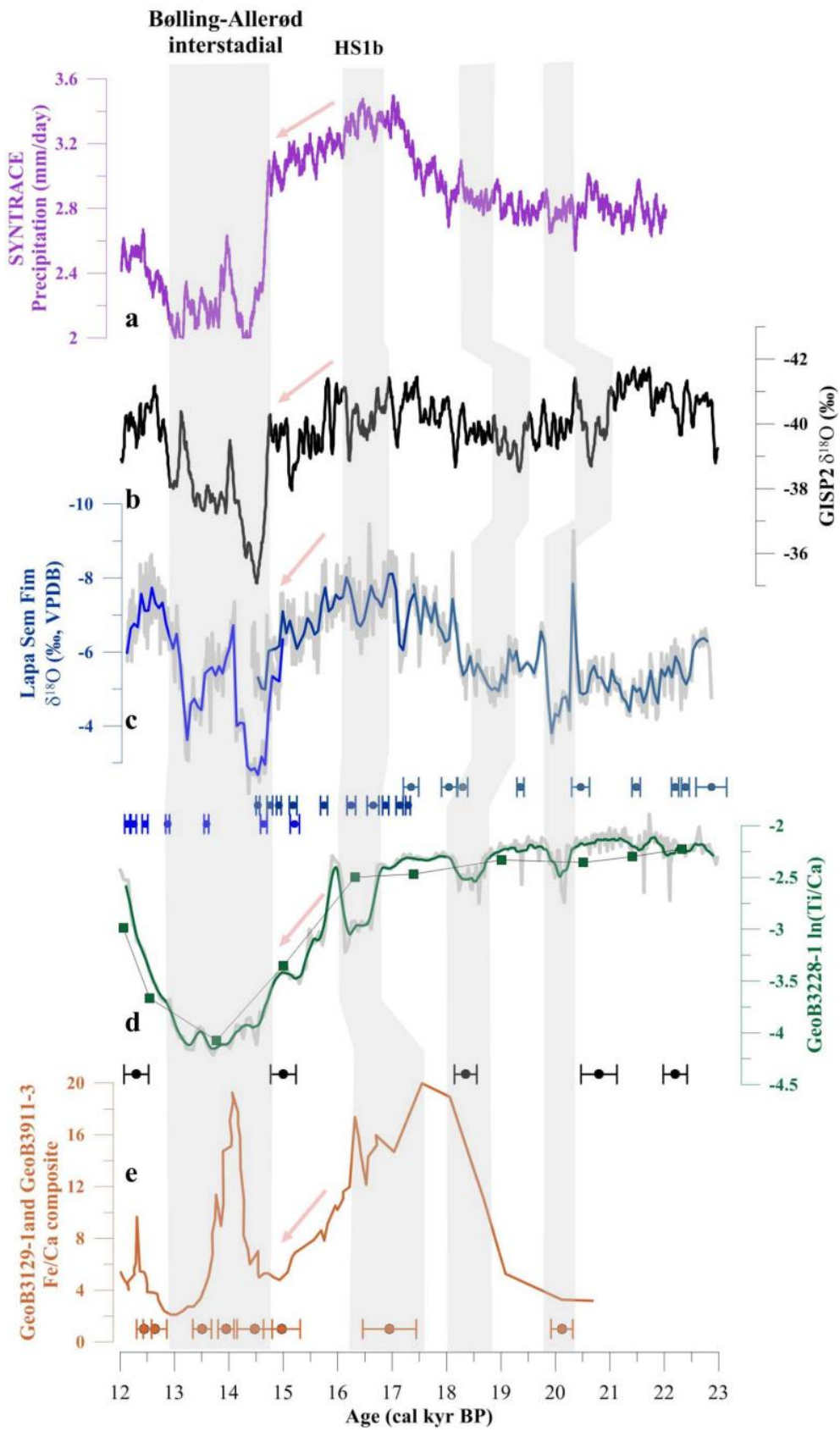

Figure 6: (a) Annual mean precipitation over eastern Brazil $\left(45^{\circ} \mathrm{W}\right.$ to $37.5^{\circ} \mathrm{W}, 20^{\circ} \mathrm{S}$ to $\left.13^{\circ} \mathrm{S}\right)$ from the SYNTRACE simulation (Liu et al., 2009), (b) GISP2 $\delta^{18} \mathrm{O}$ record on the GICC05 time-scale (Rasmussen et al., 2014), (c) Lapa Sem Fim Cave $\delta^{18} \mathrm{O}$ (parcially published by Stríkis et al., 2015), (d) GeoB3228-1 $\ln (\mathrm{Ti} / \mathrm{Ca}$ ) (this study), and (e) GeoB3129-1 and GeoB3911-3 Fe/Ca composite (Arz et al., 1999). Blue circles represent U-Th ages and correspondent error bars of the record in c. Black and orange circles represent ${ }^{14} \mathrm{C}$ datings with correspondent $2 \sigma$ uncertainty of the record in $d$. Grey bars mark periods of decreased South American Summer Monsoon intensity. Pink arrows show the decreasing precipitation trend in the transition between the end of Heinrich Stadial 1 and the Bølling-Allerød interstadial. 


\section{Conclusion}

The 2 kyr long Bølling-Allerød interstadial had a clear impact in South American climate, leading to long standing dry conditions in central eastern South America. The markedly dry conditions during Bølling-Allerød interstadial are related to weakened intensity of the South American Summer Monsoon, likely caused by reduced moisture influx to the continent due to the contemporaneous northward shift of Intertropical Convergence Zone.

\section{Acknowledgments}

We thank U. Röhl, T. Westerhold and V. Lukies for their help with the XRFscanner, and M. Zabel and S. Pape for assistance with the EDP-XRF. Logistic and technical assistance was provided by the captain and crew of the R/V Victor Hensen. This study was funded by FAPESP (grants 2012/17517-3, 2013/14599-1, and 2014/26482-4). Sample material was provided by the GeoB Core Repository at the MARUM - Center for Marine Environmental Sciences, University of Bremen, Germany. The data reported in this paper will be archived in Pangaea (www.pangaea.de).

\section{References}

469
Alves, R.A., 1999. Estudo sismoestratigráfico da Bacia do Brasil. Universidade Federal Fluminense, Niterói.

Arz, H.W., Pätzold, J., Wefer, G., 1999. Climatic changes during the last deglaciation recorded in sediment cores from the northeastern Brazilian Continental Margin. GeoMarine Letters 19, 209-218. doi:10.1007/s003670050111

Arz, H.W., Pätzold, J., Wefer, G., 1998. Correlated millennial-scale changes in surface hydrography and terrigenous sediment yield inferred from last-glacial marine deposits off northeastern Brazil. Quaternary Research 50, 157-166. doi:10.1006/qres.1998.1992

Bard, E., 1988. Correction of accelerator mass spectrometry 14C ages measured in planktonic foraminifera: Paleoceanographic implications. Paleoceanography 3, 635645. doi:10.1029/PA003i006p00635

Bastos, A.C., Quaresma, V.S., Marangoni, M.B., D'Agostini, D.P., Bourguignon, S.N., Cetto, P.H., Silva, A.E., Filho, G.M.A., Moura, R.L., Collins, M., 2015. Shelf morphology as an indicator of sedimentary regimes: A synthesis from a mixed siliciclastic-carbonate shelf on the eastern Brazilian margin. Journal of South American Earth Sciences 63, 125-136. doi:10.1016/j.jsames.2015.07.003 
485

Bender, V.B., Hanebuth, T.J.J., Chiessi, C.M., 2013. Holocene shifts of the Subtropical Shelf Front off southeastern South America controlled by high and low latitude atmospheric forcings. Paleoceanography 28, 481-490. doi:10.1002/palo.20044

Bétard, F., Peulvast, J.P., Sales, V.C., 2007. Caracterização morfopedológica de uma serra úmida no semi-árido do nordeste brasileiro: o caso do Maciço de Baturité-CE. Mercator-Revista de Geografia ....

Bony, S., Risi, C., Vimeux, F., 2008. Influence of convective processes on the isotopic composition (delta O-18 and delta D) of precipitation and water vapor in the tropics: 1 . Radiative-convective equilibrium and Tropical Ocean-Global Atmosphere-Coupled Ocean-Atmosphere Response Experiment (TOGA-COARE) simulations. Journal of Geophysical Research 113. doi:10.1029/2008JD009942

Brush, E., Fiduk, J.C., Love, F., Gibbs, P., Brink-Larsen, S., Farrow, G., 2004. The Rio Doce Canyon System in the northern Espírito Santo Basin, offshore Brazil: a model for interpreting ancient deep-water sand transportation fairways. American Association of Petroleum Geologists Search and Discovery Article.

Carmo, I. de O., Vasconcelos, P., 2004. Geochronological evidence for pervasive Miocene weathering, Minas Gerais, Brazil. Earth Surface Processes and Landforms 29, 13031320. doi:10.1002/esp.1090

Carvalho, L.M.V., Jones, C., Liebmann, B., 2004. The South Atlantic Convergence Zone: Intensity, Form, Persistence, and Relationships with Intraseasonal to Interannual Activity and Extreme Rainfall. Journal of Climate 17, 88-108. doi:10.1175/15200442(2004)017<0088:TSACZI>2.0.CO;2

Chiang, J.C.H., Friedman, A.R., 2012. Extratropical Cooling, Interhemispheric Thermal Gradients, and Tropical Climate Change. http://dx.doi.org/10.1146/annurev-earth042711-105545 40, 383-412. doi:10.1146/annurev-earth-042711-105545

Chiessi, C.M., Mulitza, S., Patzold, J., 2010. How different proxies record precipitation variability over southeastern South America. IOP Conference Series. doi:10.1088/1755-1315/9/1/012007

Chiessi, C.M., Mulitza, S., Pätzold, J., Wefer, G., Marengo, J.A., 2009. Possible impact of the Atlantic Multidecadal Oscillation on the South American summer monsoon. Geophys. Res. Lett. 36, L21707-5. doi:10.1029/2009GL039914

Cole, M.M., 1960. Cerrado, caatinga and pantanal: the distribution and origin of the savanna vegetation of Brazil. Geographical Journal 126, 168. doi:10.2307/1793957

Cruz, F.W., Burns, S.J., Karmann, I., Sharp, W.D., Vuille, M., 2006. Reconstruction of regional atmospheric circulation features during the late Pleistocene in subtropical Brazil from oxygen isotope composition of speleothems. Earth and Planetary Science Letters 248, 495-507. doi:10.1016/j.eps1.2006.06.019

Cruz, F.W., Cruz, F.W., Burns, S.J., Karmann, I., Sharp, W.D., Vuille, M., Cardoso, A.O., Ferrari, J.A., Dias, P.L.S., Viana, O., Jr., 2005. Insolation-driven changes in atmospheric circulation over the past 116,000 years in subtropical Brazil. Nature 434, 63-66. doi:10.1038/nature03365

da Silveira, I.C.A., Calado, L., de Castro, B.M., Cirano, M., Lima, J.A.M., Mascarenhas, A.D.S., 2004. On the baroclinic structure of the Brazil Current-Intermediate Western Boundary Current system at $22^{\circ}-23^{\circ} \mathrm{S}$. Geophys. Res. Lett. 31, L14308-5. doi:10.1029/2004GL020036

da Silveira, I.C.A., Schmidt, A.C.K., Campos, E.J.D., de Godoi, S.S., Ikeda, Y., 2000. A Corrente do Brasil ao largo da costa leste brasileira. Rev. bras. oceanogr. 48, 171-183. 
de Almeida, F.F.M., Hasui, Y., Neves, B.B. de B., 1976. The Upper Precambrian of South America. Boletim IG 7, 45-80.

de Oliveira, E.N., Knoppers, B.A., Lorenzzetti, J.A., Knoppers, B.A., Medeiros, P.R.P., Carneiro, M.E., de Souza, W.F.L., 2012. A satellite view of riverine turbidity plumes on the NE-E Brazilian coastal zone. Braz. j. oceanogr. 60, 283-298. doi:10.1590/S1679-87592012000300002

Deplazes, Deplazes, G., Lückge, A., Peterson, L.C., Timmermann, A., Hamann, Y., Hughen, K.A., Röhl, U., Laj, C., Cane, M.A., Sigman, D.M., Haug, G.H., 2013. Links between tropical rainfall and North Atlantic climate during the last glacial period. Nature Geosci 6, 213-217. doi:10.1038/ngeo 1712

Deschamps, P., Durand, N., Bard, E., Hamelin, B., Camoin, G., Thomas, A.L., Henderson, G.M., Okuno, J., Yokoyama, Y., 2012. Ice-sheet collapse and sea-level rise at the Bølling warming 14,600 years ago. Nature 483, 559-564. doi:10.1038/nature10902

Ekau, W., Knoppers, B.A., 1996. Sedimentation processes and Productivity in the Continental Shelf Waters off East and Northeast Brazil., Cruise Report and First Results of the Brazilian German Project JOPS-II Joint Oceanographic Projects. Bremen.

França, A.M.C., 1979. Geomorfologia da margem continental leste brasileira e das bacias oceânicas adjacentes, in:. Série Projeto REMAC, pp. 92-123.

França, M.C., Alves, I.C.C., Castro, D.F., Cohen, M.C.L., Rossetti, D.F., Pessenda, L.C.R., Lorente, F.L., Fontes, N.A., Junior, A.Á.B., Giannini, P.C.F., Francisquini, M.I., 2015. A multi-proxy evidence for the transition from estuarine mangroves to deltaic freshwater marshes, Southeastern Brazil, due to climatic and sea-level changes during the late Holocene. Catena 128, 155-166. doi:10.1016/j.catena.2015.02.005

Franke, J., Paul, A., Schulz, M., 2008. Modeling variations of marine reservoir ages during the last 45000 years. Clim. Past 4, 125-136.

Garreaud, R.D., Vuille, M., Compagnucci, R., Marengo, J., 2009. Palaeogeography, Palaeoclimatology, Palaeoecology. Palaeogeography, Palaeoclimatology, Palaeoecology 281, 180-195. doi:10.1016/j.palaeo.2007.10.032

Govin, A., Chiessi, C.M., Zabel, M., Sawakuchi, A.O., Heslop, D., Hörner, T., Zhang, Y., Mulitza, S., 2014. Terrigenous input off northern South America driven by changes in Amazonian climate and the North Brazil Current retroflection during the last $250 \mathrm{ka}$. Clim. Past 10, 843-862. doi:10.5194/cp-10-843-2014

Govin, A., Holzwarth, U., Heslop, D., Keeling, L.F., Zabel, M., Mulitza, S., Collins, J.A., 2012. Distribution of major elements in Atlantic surface sediments $\left(36^{\circ} \mathrm{N}-49^{\circ} \mathrm{S}\right)$ : Imprint of terrigenous input and continental weathering. Geochemistry, Geophysics, Geosystems 13, 1-23. doi:10.1029/2011GC003785

Govindaraju, K., Rubeska, I., Paukert, T., 1994. Compilation of working values and sample description for 383 geostandards. Geostandards and Geoanalytical Research 18, 1-42. doi:10.1111/j.1751-908X.1994.tb00502.x

Gunnell, Y., 1998. Passive margin uplifts and their influence on climatic change and weathering patterns of tropical shield regions. Global and Planetary Change 18, 47-57. doi:10.1016/S0921-8181(98)00034-4

Haug, G.H., Hughen, K.A., Sigman, D.M., Peterson, L.C., 2001. Southward migration of the intertropical convergence zone through the Holocene. Science.

Hughen, K.A., Overpeck, J.T., Peterson, L.C., Trumbore, S., 1996. Rapid climate changes in the tropical Atlantic region during the last deglaciation. Nature 380, 51-54. 
doi:10.1038/380051a0

Jaeschke, A., Rühlemann, C., Heil, G., Lohmann, G., Arz, H.W., 2007. Coupling of millennial-scale changes in sea surface temperature and precipitation off northeastern Brazil with high-latitude climate shifts during the last glacial period. Paleoceanography 22, PA4206. doi:10.1029/2006PA001391

Jansen, J.H.F., Van der Gaast, S.J., Koster, B., Vaars, A.J., 1998. CORTEX, a shipboard XRF-scanner for element analyses in split sediment cores. Marine Geology 151, 143153. doi:10.1016/S0025-3227(98)00074-7

Jennerjahn, T.C., Ittekkot, V., Arz, H.W., Behling, H., Pätzold, J., Wefer, G., 2004. Asynchronous terrestrial and marine signals of climate change during Heinrich events. Science 306, 2236-2239. doi:10.1126/science.1102490

Knoppers, B.A., Ekau, W., Figueiredo, A.G., 1999. The coast and shelf of east and northeast Brazil and material transport. Geo-Marine Letters 19, 171-178.

Lambeck, K., Chappell, J., 2001. Sea Level Change Through the Last Glacial Cycle. Science 292, 679-686. doi:10.1126/science.1059549

Liebmann, B., Kiladis, G.N., Marengo, J.A., Ambrizzi, T., Glick, J.D., 1999. Submonthly convective variability over South America and the South Atlantic convergence zone. Journal of Climate 12, 1877-1891. doi:10.1175/1520-0442

Liu, Z., Otto-Bliesner, B.L., He, F., He, F., Brady, E.C., Tomas, R., Clark, P.U., Carlson, A.E., Lynch-Stieglitz, J., Curry, W.B., Brook, E.J., Erickson, D., Jacob, R., Kutzbach, J., Cheng, J., 2009. Transient Simulation of Last Deglaciation with a New Mechanism for Bolling-Allerod Warming. Science 325, 310-314. doi:10.1126/science.1171041

Machado, I., Barros, L.M., Sampaio, E., 1997. Phenology of caatinga species at Serra Talhada, PE, northeastern Brazil. Biotropica 29, 57-68.

Mahiques, M.M. de, Bícego, M.C., Silveira, I.C.A., Sousa, S.H.M., Lourenço, R.A., Fukumoto, M.M., 2005. Modern sedimentation in the Cabo Frio upwelling system, Southeastern Brazilian shelf. Annals of the Brazilian Academy of Sciences 77, 535548. doi:10.1590/S0001-37652005000300013

Mahiques, M.M., Fukumoto, M.M., Silveira, I.C.A., Figueira, R.C.L., Bícego, M.C., Lourenço, R.A., Mello-e-Sousa, S.H., 2007. Sedimentary changes on the Southeastern Brazilian upper slope during the last 35,000 years. Annals of the Brazilian Academy of Sciences 79, 171-181. doi:10.1590/S0001-37652007000100018

Maia, M.A.M., 2013. Geodiversidade das áreas adjacentes à Cadeia Submarina de VitóriaTrindade: construção e aplicação de um modelo de compartimentação em macroescala do assoalho oceânico. Instituto de Geociências, Universidade Federal do Rio de Janeiro.

Mangerud, J., Andersen, S.T., Berglund, B.E., Donner, J.J., 1974. Quaternary stratigraphy of Norden, a proposal for terminology and classification. Boreas 3, 109-126. doi:10.1111/j.1502-3885.1974.tb00669.x

Marengo, J.A., Liebmann, B., Kousky, V.E., Filizola, N.P., Wainer, I., 2001. Onset and end of the rainy season in the Brazilian Amazon Basin. Journal of Climate 14, 833-852.

Marques, M., da Costa, M.F., Mayorga, M.I. de O., Pinheiro, P.R.C., 2004. Water environments: anthropogenic pressures and ecosystem changes in the atlantic drainage basins of Brazil. AMBIO: A Journal of the Human Environment 33, 68-77. doi:10.1579/0044-7447-33.1.68

Massé, L., Faugères, J.C., Pujol, C., Pujos, A., LaBeyrie, L.D., Bernat, M., 1996. Sediment flux distribution in the Southern Brazil Basin during the late Quaternary: The role of 
deep-sea currents. Sedimentology 43, 115-132. doi:10.1111/j.1365-

3091.1996.tb01463.x

Mix, A., Bard, E., Schneider, R., 2001. Environmental processes of the ice age: land, oceans, glaciers (EPILOG). Quaternary Science Reviews 20, 627-657. doi:10.1016/S0277-3791(00)00145-1

Nace, T.E., Baker, P.A., Dwyer, G.S., Silva, C.G., Rigsby, C.A., Burns, S.J., Giosan, L., Otto-Bliesner, B., Liu, Z., Zhu, J., 2014. The role of North Brazil Current transport in the paleoclimate of the Brazilian Nordeste margin and paleoceanography of the western tropical Atlantic during the late Quaternary. Palaeogeography, Palaeoclimatology, Palaeoecology 415, 3-13. doi:10.1016/j.palaeo.2014.05.030

Nagai, R.H., de Mello e Sousa, S.H., Lourenco, R.A., Bicego, M.C., de Mahiques, M.M., 2010. Paleoproductivity Changes During the Late Quaternary in the Southeastern Brazilian Upper Continental Margin of the Southwestern Atlantic. Braz. j. oceanogr. 58, 31-41. doi:10.1590/S1679-87592010000500004

Nobre, P., Shukla, J., 1996. Variations of sea surface temperature, wind stress, and rainfall over the tropical Atlantic and South America. Journal of Climate 9, 2464-2479. doi:10.1175/1520-0442(1996)009<2464:VOSSTW>2.0.CO;2

Paillard, D., Labeyrie, L., Yiou, P., 2011. Macintosh Program performs time-series analysis. Eos Trans. AGU 77, 379-379. doi:10.1029/96EO00259

Pätzold, J., Arz, H.W., Absher, T.M., Barreto, A.V., Bertilao da Silva, L.F., Draschba, S., Figueiredo, A.G., Freire, G.S.S., Gomez, A.S., Morais, J.O., Roscher, N.A., Rosenboom, W., Rühlermann, C., Souza, S.H.M., Tintelnot, M., 1996. Report and preliminary results of RV Victor Hensen cruise JOPS II: leg 6 Fortaleza - Recife and leg 8 Vitória -Vitória (No. 76), Berichte Fachbereich Universität Bremen. Berichte, Fachbereich Geowissenschaften.

Peel, M.C., Finlayson, B.L., McMahon, T.A., 2007. Updated world map of the KöppenGeiger climate classification. Hydrology and Earth System Sciences Discussions 4, 439-473.

Peterson, L.C., Haug, G.H., Hughen, K.A., Röhl, U., 2000. Rapid changes in the hydrologic cycle of the tropical Atlantic during the last glacial. Science 290, 1947-1951. doi:10.1126/science.290.5498.1947

Peterson, R.G., Stramma, L., 1991. Upper-level circulation in the South Atlantic Ocean. Progress in Oceanography 26, 1-73. doi:10.1016/0079-6611(91)90006-8

Raia, A., Cavalcanti, I.F.A., 2008. The Life Cycle of the South American Monsoon System. Journal of Climate 21, 6227-6246. doi:10.1175/2008JCLI2249.1

Rasmussen, S.O., Andersen, K.K., Svensson, A.M., Steffensen, J.P., Vinther, B.M., Clausen, H.B., Siggaard-Andersen, M.L., Johnsen, S.J., Larsen, L.B., Dahl-Jensen, D., Bigler, M., Röthlisberger, R., Fischer, H., Goto-Azuma, K., Hansson, M.E., Ruth, U., 2006. A new Greenland ice core chronology for the last glacial termination. Journal of Geophysical Research: Oceans 111, D06102-16. doi:10.1029/2005jd006079

Reimer, P.J., Bard, E., Bayliss, A., Beck, J.W., Blackwell, P.G., Ramsey, C.B., Buck, C.E., Cheng, H., Edwards, R.L., Friedrich, M., Grootes, P.M., Guilderson, T.P., Haflidason, H., Hajdas, I., Hatté, C., Heaton, T.J., Hoffmann, D.L., Hogg, A.G., Hughen, K.A., Kaiser, K.F., Kromer, B., Manning, S.W., Niu, M., Reimer, R.W., Richards, D.A., Scott, E.M., Southon, J.R., Staff, R.A., Turney, C.S.M., van der Plicht, J., 2013. IntCal13 and Marine13 radiocarbon age calibration curves 0-50,000 years cal BP. Radiocarbon 55, 1869-1887. doi:10.2458/azu_js_rc.55.16947 
673

674

675

676

677

678

679

680

681

682

683

684

685

686

687

688

689

690

691

692

693

694

695

696

697

698

699

700

701

702

703

704

705

706

707

708

709

710

711

712

713

714

715

716

717

718

719

Risi, C., Bony, S., Vimeux, F., 2008. Influence of convective processes on the isotopic composition $(\delta 18 \mathrm{O}$ and $\delta \mathrm{D})$ of precipitation and water vapor in the tropics: 2 . Physical interpretation of the amount effect. Journal of Geophysical Research: Oceans (19782012) 113, D19306. doi:10.1029/2008JD009943

Schmid, C., Podestá, G., Zenk, W., 1995. The Vitória Eddy and its relation to the Brazil Current. Journal of Physical Oceanography 25, 2532-2547.

Schreiner, S., de Souza, M.B.F.M., Migliorelli, J.P.R., 2009. Modelo digital da geomorfologia do fundo oceânico do centro-sul da Bacia do Espírito Santo e norte da Bacia de Campos. Boletim de Geociências da Petrobrás 17, 365-369.

Shen, C.-C., Lawrence Edwards, R., Cheng, H., Dorale, J.A., Thomas, R.B., Bradley Moran, S., Weinstein, S.E., Edmonds, H.N., 2002. Uranium and thorium isotopic and concentration measurements by magnetic sector inductively coupled plasma mass spectrometry. Chemical Geology 185, 165-178. doi:10.1016/S0009-2541(01)00404-1

Souza, W.F.L., Knoppers, B.A., 2003. Fluxos de água e sedimentos a costa leste do Brasil: relações entre a tipologia e pressões antrópicas. Geochimica Brasiliensis 17, 57-74.

Stramma, L., England, M.H., 1999. On the water masses and mean circulation of the South Atlantic Ocean. Journal of Geophysical Research: Oceans (1978-2012) 104, 2086320883. doi:10.1029/1999JC900139

Stríkis, N.M., Chiessi, C.M., Cruz, F.W., Vuille, M., Cheng, H., Barreto, E.A. de S., Mollenhauer, G., Karsten, S., Karmann, I., Bernal, J.P., Sales, H.D.R., 2015. Timing and structure of Mega-SACZ events during Heinrich Stadial 1. Geophys. Res. Lett. 42, 1-8. doi:10.1002/(ISSN)1944-8007

Stríkis, N.M., Cruz, F.W., Cheng, H., Karmann, I., Edwards, R.L., Vuille, M., Wang, X., de Paula, M.S., Novello, V.F., Auler, A.S., 2011. Abrupt variations in South American monsoon rainfall during the Holocene based on a speleothem record from centraleastern Brazil. Geology 39, 1075-1078. doi:10.1130/G32098.1

Stuiver, M., Reimer, P.J., 1993. Extended ${ }^{14} \mathrm{C}$ data base and revised CALIB $3.0{ }^{14} \mathrm{C}$ age calibration program. Radiocarbon 35, 215-230.

Summerhayes, C.P., de Melo, U., Barretto, H.T., 1976. The influence of upwelling on suspended matter and shelf sediments off southeastern Brazil. Journal of Sedimentary Petrology 46, 819-828.

Tintelnot, M., 1995. Transport and deposition of fine-grained sediments on the Brazilian continental shelf as revealed by clay mineral distribuition. Ruprecht-Karls-Universität Heidelberg, Heidelberg.

Tintelnot, M., Brichta, A., Morais, J.O., 1998. Clay mineralogy of river sediments on the Brazilian coast. Jahrestagung der DTTG 6, 1-15.

Toledo, F., 2008. Tracing past circulation changes in the western South Atlantic based on planktonic foraminifera. RBP 11, 169-178. doi:10.4072/rbp.2008.3.03

Toledo, F.A.L., Cachão, M., Costa, K.B., Pivel, M.A.G., 2007. Planktonic foraminifera, calcareous nannoplankton and ascidian variations during the last $25 \mathrm{kyr}$ in the Southwestern Atlantic: A paleoproductivity signature? Marine Micropaleontology 64, 67-79. doi:10.1016/j.marmicro.2007.03.001

Vera, C., Higgins, W., Amador, J., Ambrizzi, T., 2006. Toward a unified view of the American monsoon systems. Journal of Sedimentary Petrology 19, 4977-5000. doi:10.1175/JCLI3896.1

Voigt, I., Henrich, R., Preu, B.M., Piola, A.R., Hanebuth, T.J.J., Schwenk, T., Chiessi, C.M., 2013. A submarine canyon as a climate archive - Interaction of the Antarctic 

Geology 341, 46-57. doi:10.1016/j.margeo.2013.05.002

Wang, X., Auler, A.S., Edwards, R.L., Cheng, H., Cristalli, P.S., Smart, P.L., Richards, D.A., Shen, C.-C., 2004. Wet periods in northeastern Brazil over the past $210 \mathrm{kyr}$ linked to distant climate anomalies. Nature 432, 740-743. doi:10.1038/nature03067

Wang, X., Auler, A.S., Edwards, R.L., Cheng, H., Ito, E., Wang, Y., Kong, X., Solheid, M., 2007. Millennial-scale precipitation changes in southern Brazil over the past 90,000 years. Geophys. Res. Lett. 34, L23701. doi:10.1029/2007GL031149

Weldeab, S., Schneider, R.R., Kölling, M., 2006. Deglacial sea surface temperature and salinity increase in the western tropical Atlantic in synchrony with high latitude climate instabilities. Earth and Planetary Science Letters 241, 699-706. doi:10.1016/j.epsl.2005.11.012

Weltje, G.J., Tjallingii, R., 2008. Calibration of XRF core scanners for quantitative geochemical logging of sediment cores: Theory and application. Earth and Planetary Science Letters 274, 423-438. doi:10.1016/j.epsl.2008.07.054

Zhang, Y., Chiessi, C.M., Mulitza, S., Zabel, M., Trindade, R.I.F., Hollanda, M.H.B.M., Dantas, E.L., Govin, A., Tiedemann, R., Wefer, G., 2015. Origin of increased terrigenous supply to the NE South American continental margin during Heinrich Stadial 1 and the Younger Dryas. Earth and Planetary Science Letters 1-12. doi:10.1016/j.epsl.2015.09.054 